
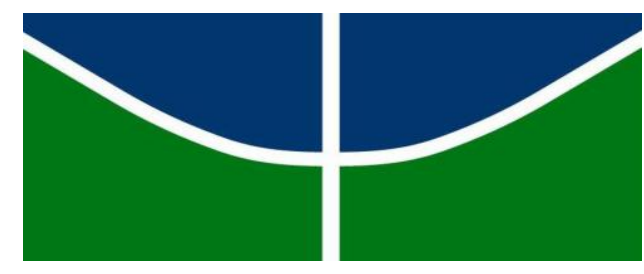

Universidade de Brasília - UnB

Instituto de Ciências Sociais - ICS

Centro de Pesquisa e Pós-Graduação sobre as Américas - CEPPAC

Programa de Pós-Graduação em Estudos Comparados sobre as Américas

A construção da nação guarani pela Asamblea del Pueblo Guaraní a partir da comemoração do massacre de Kuruyuki

Wildes Souza Andrade

Brasília, 2014. 


$$
\begin{gathered}
\text { Universidade de Brasília - UnB } \\
\text { Instituto de Ciências Sociais - ICS }
\end{gathered}
$$

Centro de Pesquisa e Pós-Graduação sobre as Américas - CEPPAC

Programa de Pós-Graduação em Estudos Comparados sobre as Américas

\section{A construção da nação guarani pela Asamblea del Pueblo Guaraní a partir da comemoração do massacre de Kuruyuki}

\section{Wildes Souza Andrade}

Dissertação apresentada ao Programa de PósGraduação em Estudos Comparados sobre as Américas como pré-requisito à obtenção do título de Mestre em Ciências Sociais.

Área de Concentração: Estudos Comparados sobre as Américas

Linha de Pesquisa: Etnicidade, Raça e Povos Indígenas nas Américas

Orientador: Prof. Dr. Cristhian Teófilo da Silva

Brasília, 2014. 


\section{CESSÃO DE DIREITOS}

É concedida à Universidade de Brasília permissão para reproduzir cópias desta dissertação de mestrado e para emprestar ou vender tais cópias somente para propósitos acadêmicos e científicos. $\mathrm{O}$ autor reserva outros direitos de publicação e nenhuma parte dessa dissertação de mestrado pode ser reproduzida sem autorização por escrito do autor.

AUTOR: Wildes Souza Andrade

TÍTULO: A construção da nação guarani pela Asamblea del Pueblo Guaraní a partir da comemoração do massacre de Kuruyuki.

GRAU: Mestre

ANO: 2014

\section{REFERÊNCIA BIBLIOGRÁFICA}

ANDRADE, Wildes Souza. A construção da nação guarani pela Asamblea del Pueblo Guaraní a partir da comemoração do massacre de Kuruyuki. 2014. 115 f. Dissertação (Mestrado em Ciências Sociais) - Universidade de Brasília, Brasília, 2014.

\section{FICHA CATALOGRÁFICA}

Ficha catalográfica elaborada pela Biblioteca Central da Universidade de Brasilia. Acervo 1018259.

Andrade, Wi Ides Souza.

A553c A construção da nação guarani pela Asamblea del Pueblo Guaraní a partir da comemoração do massacre de Kuruyuki / Wi Ides Souza Andrade. -- 2014.

$116 \mathrm{f}$. : il. ; $30 \mathrm{~cm}$.

Dissertação (mestrado) - Universidade de Brasília, Centro de Pesquisa e Pós-Graduação sobre as Américas, Programa de Pós-Graduação em Estudos Camparados sobre as Américas, 2014.

Inclui bibliografia.

Orientação: Cristhian Teófilo da Silva.

1. Asamblea del Pueblo Guaraní. 2. Índios Guarani - Bol ívia. I. Silva, Cristhian Teófilo da. II. Título.

COU $39(84=082)$ 


$$
\begin{gathered}
\text { Universidade de Brasília - UnB } \\
\text { Instituto de Ciências Sociais - ICS }
\end{gathered}
$$

Centro de Pesquisa e Pós-Graduação sobre as Américas - CEPPAC

Programa de Pós-Graduação em Estudos Comparados sobre as Américas

A construção da nação guarani pela Asamblea del Pueblo Guaraní a partir da comemoração do massacre de Kuruyuki

Wildes Souza Andrade

Dissertação submetida ao Programa de Pós-Graduação em Estudos Comparados sobre as Américas da Universidade de Brasília como parte dos requisitos necessários para a obtenção do grau de mestre em Ciências Sociais.

Área de Concentração: Estudos Comparados sobre as Américas.

\section{APROVADA POR:}

Prof. Dr. Cristhian Teófilo da Silva. (CEPPAC/UnB)

(Presidente)

Prof. Dr. Gustavo Hamilton de Sousa Menezes. (FUNAI)

(Examinador Externo)

Prof. Dr. Jaime de Almeida. (HIS/UnB e PPG/CEPPAC/UnB)

(Examinador Interno)

Prof. Dr. Stephen Grant Baines. (DAN/UnB e PPG/CEPPAC/UnB)

(Suplente)

Brasília, 08 de outubro de 2014. 


\section{AGRADECIMENTOS}

Agradeço à minha família, a quem dedico este trabalho. Meu porto seguro de onde parto, mas sempre volto a ancorar. Minha mãe Celina, meu pai Anísio e meu irmão Willian, que sempre me apoiaram e incentivaram.

Ao meu orientador, Prof. Cristhian Teófilo da Silva, sempre muito ágil e preciso. Agradeço a presteza e a oportunidade de concessão de recursos para trabalho de campo na Bolívia, bem como a oportunidade de atuar em um laboratório de estudo e pesquisa, o LAEPI. Essas condições foram profícuas e motivadoras para a realização da pesquisa.

Agradeço à Profa. Izabel Missagia (UFRRJ) e ao meu amigo Matheus Guimarães. Em 2009, mesmo eu residindo em outro país, eles viabilizaram minha bolsa de iniciação científica na UFG para eu iniciar a pesquisar sobre os guaranis na Bolívia. Também, à Izabel por ter me apresentado o tema massacre de Kuruyuki e pelas primeiras orientações na área. E, também, ao Matheus e a toda galera da "Revista Senso Comum", com que construí minhas primeiras experiências universitárias.

Agradeço aos meus primeiros professores de Ciências Sociais da UFG: ao Prof. Marco Antonio Lazarin e à Profa. Joana Aparecida Silva, minhas primeiras referências na etnologia indígena e também pela oportunidade de trabalhar como monitor na Licenciatura Indígena da UFG; à Profa. Mônica Pechincha, pela orientação no TCC e por me apresentar outras possibilidades de etnologia; ao Prof. Luiz Mello, pela primeira experiência com pesquisa e pela discussão sobre gêneros e sexualidades. À Profa. Marlene Ossami (IGPA/PUC-GO), pela oportunidade de conhecer a Terra Indígena Carretão, minha primeira experiência de campo em área indígena.

Agradeço aos professores do CEPPAC/UnB que tanto contribuíram para minha formação como pesquisador e docente das Ciências Sociais preocupado com as Américas. Às Profa. Simone Rodrigues e Profa. Rebecca Igreja, pelas contribuições metodológicas. À Profa. Flávia Barros, pelo debate acerca da sociedade civil nas Américas.

Agradeço aos professores membros da banca examinadora. Ao Gustavo Hamilton Menezes (FUNAI), por aceitar prontamente o convite para a defesa da dissertação. Ao Prof. José Pimenta (DAN/UnB), pelas contribuições propostas na qualificação, mas, sobretudo, pelas valiosas ideias no decorrer de uma disciplina optativa. Ao Prof. Stephen, presente na qualificação e membro suplente da defesa da dissertação. Ao Prof. Jaime de Almeida, sempre 
prestativo, me acolheu como estagiário docente na sua disciplina da graduação em história e, desde então, contribuiu para minha pesquisa de mestrado, presente na qualificação e na defesa final.

Agradeço à antropóloga Isabelle Combès e ao historiador Mathiel Silva, por me aproximarem dos guaranis em Camiri.

Às atenciosas amizades, de Goiânia e Brasília, que me acompanharam durante o mestrado. Agradeço à Lais Moreira, Amanda Vieira, Iran Nunes, Iara Lays, Pauliany Martins, Aline Barcelos, Humberto Borges, Flor Silvestre, Sebastián Granda, Estevão Fernandes, Mauro Gouveia, Jairo Muñoz, Sílvia Almeida, Nathália Porto, Eliana Carla, Éder Brito, João Lúcio e todos outros amigos que contribuíram indiretamente. Ao Thiago Dornelles, por me ajudar a me conhecer melhor, nobre convivência para o andamento deste trabalho.

Agradeço à Lilian Barcelos, pela amizade e acolhida em Brasília desde a seleção do mestrado. Agradeço ao amigo André Luiz Filgueira, ex-ceppaquiano que me apresentou o Centro, me motivou na seleção e também durante o curso. À Lorena França, amiga de longos caminhos percorridos, parceira também da questão indígena, agradeço pelas conversas sobre minhas angústias no mestrado. Ao Warley Costa, pela generosidade em compartilhar ideias e materiais sobre a Bolívia. Ao Ciro Gonçalves, por desenhar nesta dissertação.

Em Camiri: agradeço aos arakuaaiya Felipe Román Montenegro e Antonio Mendez, pelas horas de conversas, por me acompanharem em visitas em campo e, sobretudo, pela confiança e generosidade depositadas em mim. Agradeço à Damary Mendez, pelas inúmeras ajudas em relação ao espanhol e ao guarani em Camiri. A todos os mburuvichas e técnicos da APG, sobretudo Arlet Salazar, Federico Villa Chilimani, Ena Taborga, Sérgio, Faustino Flores, Jorge Changaray e Victor Rodrigues. Ao Felipe Román Chumira pela amizade.

Aos intelectuais guaranis Elio Ortiz (in memoriam) e Elias Caurey. Ortiz e eu conversamos diversas vezes, ele me concedeu entrevista e facilitou materiais em campo. Lamentavelmente, ele faleceu no dia 2 de agosto.

Além de várias outras pessoas na Bolívia, com carinho, às crianças guaranis da comunidade de Itanambikua, que me brindavam todas as tardes (em aulas de matemática de um "estranho" professor) com seus sorrisos mais sinceros, com abraços de carinho e com histórias inimagináveis. 
Aos amigos do CouchSurfing que me receberam em Santa Cruz de la Sierra e me ajudaram a compreender e experimentar um pouco da bolivianidade, para além da questão guarani: Ruby Toledo e sua preciosa amizade, sempre fazendo me sentir em casa; Eva Kris Cabero, pela bonita disposição em ajudar um estudante forasteiro; e Federico Rojas e sua família, que me receberam tão aconchegadamente em seu lar.

Ainda na Bolívia, agradeço aos servidores do Museo de Historia y Archivo Histórico da Universidad Autónoma Gabriel René Moreno, algumas das ilustrações desta dissertação são do acervo do Centro de Investigación, Posgrado y Conservación Amazónica - CIPCA, Cordillera, em Camiri, Apoyo Para el Campesino-Indígena del Oriente Boliviano - APCOB e Teko Guarani.

Com gratidão, registro que recebi recursos do governo brasileiro para o desenvolvimento deste trabalho. Recebi auxílio financeiro do Decanato de Pesquisa e Pós-Graduação (DPP) da UnB para apresentação de trabalho, sobre a pesquisa, em congresso. Minhas duas incursões a campo foram custeadas parcialmente pelo CNPq, no âmbito do projeto Povos Indígenas, Estados Nacionais e Indigenismo em perspectiva comparada, coordenado pelo Prof. Cristhian Teófilo da Silva (LAEPI/CEPPAC/UnB). E durante dois anos fui bolsista de mestrado da CAPES. 


\title{
RESUMO
}

O objetivo desta dissertação é compreender as características do processo de construção da nação guarani a partir da comemoração do massacre do Kuruyuki, evento gerenciado pela Asamblea del Pueblo Guaraní (APG). Observo que a produção cultural da comemoração de Kuruyuki, bem como todo o processo de construção de uma consciência nacional guarani, é uma estratégia de estabelecimento de uma linguagem, compreensível aos karai, que visibiliza a APG diante do Estado, sociedade nacional, os guaranis de modo geral e outros povos indígenas da região. Para o movimento guarani na Bolívia, expressar-se em termos nacionais, com datas comemorativas, bandeira, hino, intelectuais etc., é uma forma de se configurarem como sujeitos políticos autonomistas e em relação ao Estado, sem que isso implique necessariamente desejo de construir um Estado guarani, ao menos até o presente momento. Apesar de esse processo se apropriar estrategicamente de um idioma político eurocêntrico nação, direitos, cultura -, ele busca iniciativas de desenvolvimento descentralizadas e uma consciência anticolonialista. Ao final, no âmbito do debate teórico das Ciências Sociais sobre os indígenas, endosso o enfoque que defende que estes desempenham papel ativo diante das imposições coloniais e republicanas, até mesmo em condições de extrema violência e abusos, como é o caso do massacre de Kuruyuki, que, agora, é ressignificado e comemorado.

Palavras-chave: nação, comemoração, guaranis, Bolívia.

\begin{abstract}
This dissertation work aims to comprehend the characteristics in the nation-building process of Guarani's peoples from the start point of the Kuruyuki massacre commemoration - an event managed by the Guarani People Assembly $(A P G)$. It is observed in this dissertation that cultural production surrounding Kuruyuki commemoration, as well as the whole process of constructing national conscience, is a strategy towards stablishing an understandable language for karai (non-guaranis) and that evidences APG in front of the Bolivian State, the Bolivian national society and all guaranis in general, as well as other indigenous peoples in the region. For the guarani movement in Bolivia, expressing themselves in terms of nation, with commemorative dates, flags, anthems, intellectual representatives, etc., is a form of setting as political autonomist subjects vis-a-vis the State, without meaning that it represents a desire of building an independent guarani State, at least to the present. Furthermore than appropriating strategically of an eurocentric political language - nation, rights, culture, etc. - as a process, it looks for initiatives of decentralized development and an anti-colonialist conscience. Considering the theoretical discussion of the social sciences on indigenous peoples, this dissertation reinforces the active role of the indigenous peoples in front of the colonial and republican impositions. Even under conditions of extreme violence and abuse, as in the case of Kuruyuki massacre, which now is resignified and commemorated.
\end{abstract}

Key-words: nation-building, commemoration, guarani people, Bolivia. 


\section{LISTA DE FIGURAS}

Figura 1 Fragmento do mapa da Bolívia com destaque para o Departamento de

Santa Cruz (cidade de Santa Cruz de la Sierra e Camiri) e Chuquisaca (Kuruyuki e Ivo).

Figura 2 Fragmento do mapa do Departamento Chuquisaca, em destaque a Ruta 9, Comunidade de Kuruyuki e Ivo e as trincheiras.

Figura 3 Fragmento do mapa da Comunidade de Ivo, Departamento Chuquisaca, em destaque a escola indígena, o posto de saúde, o palanque, a igreja, o cemitério e a Unibol.

Figura 4 Panorama da cidade de Camiri.

Figura 5 Entrada da APG Nacional em Camiri.

Figura 6 Concentração em frente à Catedral de Camiri para comemoração de Kuruyuki, em 1994.

Figura 7 Marcha guarani saindo de Camiri em direção à Kuruyuki, em 1992.

Figura 8 Marcha guarani próximo a Salinas, depois de uma chuva, em direção à Kuruyuki, em 1992.

Figura 9 Missa em frente à Iglesia San Buenaventura em homenagem aos mortos em Kuruyuki, 1992.

Figura 10 Marcha a Kuruyuki, próximo à localidade de Cuevo, 1992.

Figura 11 Marcha em direção à Kuruyuki, 1992.

Figura 12 Autoridades do Estado e lideranças guaranis na primeira comemoração, 1992.

Figura 13 Cruz em homenagem aos mortos no massacre, Comunidade de Ivo, 1992.

Figura 14 Comemoração da morte de Apiaguaiqui Tumpa, 29 de março de 1992, Monteagudo.

Figura 15 Sepultamento dos restos mortais dos guerreiros de Kuruyuki no ossuário do cemitério da comunidade de Ivo, 1992.

Figura 16 Chegada do helicóptero com presidente Jaime Paz Zamora na primeira comemoração do massacre de Kuruyuki, 1992, em Ivo.

Figura 17 Estátua Guerrero Chiriguano, o líder Apiaguaiki na rotatória do Segundo Anillo, próximo à Via La Guardia na cidade de Santa Cruz de la Sierra. 
Figura 18 Estátua do guerreiro guarani Apiaguaiki com uma flecha em posição de ataque. Em Camiri, na avenida Petrolera com 24 de Septiembre.

Figura 19 Em trabalho de campo entre crianças guaranis na Unidad Educativa Juan Pablo Rivero Herbas, escola indígena em Itanambikua, 2014.

Figura 20 Área onde foram realizadas as escavações de 1992 em busca dos 101 restos mortais, porém apresenta processo erosivo. Kuruyuki, 2014.

Figura 21 Felipe Román mostrando cerâmicas encontradas na área em que realizou as escavações de 1992 em busca dos restos mortais. Kuruyuki, 2014.

Figura 22 Iglesia San Boaventura, Ivo, 2014.

Figura 23 Cruz em homenagem aos mortos no massacre de Kuruyuki, em frente à Iglesia San Boaventura, Ivo, 2014.

Figura 24 Placa recordatória da Cruz aos mortos em Kuruyuki em frente à Igreja de Ivo, 2014.

Figura 25 Rua principal da comunidade de Ivo, 2014.

Figura 26 Palanque/salão de festa na comunidade de Ivo, local onde acontecem os atos cívicos da comemoração de Kuruyuki, 2014.

Figura 27 As trincheiras do massacre em Kuruyuki, 2014.

Figura 28 Vista panorâmica da Unibol, Kuruyuki, 2013.

Figura 29 VIII Marcha Indígena, 11 de outubro de 2011. Participação da APG com bandeira da nação guarani: única bandeira com azul.

Figura 30 Ossuário com restos mortais dos guerreiros do massacre de Kuruyuki. Cemitério de Ivo, 2004.

Figura 31 Translado dos ossos dos guerreiros em urnas funerárias para o Cemitério em Ivo, 1992.

Figura 32 Casal guarani de Macharetí dança na comemoração de Kuruyuki de 2008 .

Figura 33 Palanque na comemoração de Kuruyuki de 2008.

Figura 34 Pessoas se escondem do forte sol do Chaco na comemoração de Kuruyuki de 2009, Ivo.

Figura 35 Venda de cerâmica guarani na comemoração de Kuruyuki de 2010, Ivo.

Figura 36 Presença do Exército na comemoração de Kuruyuki de 2010, Ivo. 
Figura 37 Pessoas durante a comemoração de Kuruyuki de 2010, Ivo.

Figura 38 Orquestra de Palmarito durante a comemoração de Kuruyuki de 2010, Ivo.

Figura 39 Alunas da Escola Normal de Camiri cantando o Hino a Kuruyuki na comemoração de 2010, Ivo.

Figura 40 Wilson Changaray Taborga, ex-presidente da APG Nacional e atual deputado guarani, hasteando a bandeira guarani na comemoração de 2010, Ivo.

Figura 41 Em diálogo no centro da foto: presidente da APG Nacional, Faustino Flores e o presidente Evo Morales, na comemoração de 2013, Ivo.

Figura 42 Nelson Bartolo, secretário de Recursos Naturais da APG Nacional, entregando um projeto para o presidente Morales na comemoração de 2013, Ivo.

Figura 43 Cartaz do filme Yvy maraey - Tierra sin mal, do diretor Juan Carlos Valdivia, sobre a nação guarani, lançado em 2013.

Figura 44 Fotografia do filme Yvy maraey - Tierra sin mal, do diretor Juan Carlos Valdivia. O encontro intercultural entre o karai e o guarani.

Figura 45 Felipe Román, Juan Carlos Valdivia e Elio Ortiz no lançamento do filme Yvy maraey - Tierra sin mal, em La Paz. 


\section{LISTA DE SIGLAS}

APCOB Apoyo Para el Campesino-Indígena del Oriente Boliviano

APG Asamblea del Pueblo Guaraní

CAPES Coordenação de Aperfeiçoamento de Pessoal de Nível Superior

$\mathrm{CCCH} \quad$ Consejo de Capitanes Guaraníes de Chuquisaca

CEJIS Centro de Estudios Jurídicos e Investigación Social

CEPPAC Centro de Pesquisa e Pós-Graduação sobre as Américas

CEPOG Consejo Educativo Guaraní

CNPq Conselho Nacional de Desenvolvimento Científico e Tecnológico

CIDOB Confederación de Pueblos Indígenas de Bolivia

CIAEE Congresso Iberoamericano de Arqueologia, Etnologia e Etno-história

CSUTCB Confederación Sindical Única de Trabajadores Campesinos de Bolivia

EIB Educación Intercultural Bilingüe

ERBOL Red de Educación Radiofónica de Bolivia

INRA Instituto Nacional de Reforma Agraria

LAEPI Laboratório de Estudos e Pesquisas em Movimentos Indígenas, Políticas Indigenistas e Indigenismo

MAS Movimiento al Socialismo

OIT Organização Internacional do Trabalho

ONG Organizações Não Governamentais

TIOC Territorios Indígena Originario Campesinos

UFG Universidade Federal de Goiás

UFGD Universidade Federal da Grande Dourados

UFRRJ Universidade Federal Rural do Rio de Janeiro

UnB Universidade de Brasília 


\section{LISTA DE VOCABULÁRIO GUARANI}

\begin{tabular}{|c|c|}
\hline Arakuaaiya & Sábio \\
\hline Arete Guasu & grande festa \\
\hline Karai & branco, não indígena \\
\hline Kaami & Camiri \\
\hline Mburuvicha & Liderança \\
\hline Mborerekua & Reciprocidade \\
\hline Nãnderekó & modo de ser \\
\hline Iva marei & Terra Sem Mal \\
\hline Teku & Sabedoria \\
\hline
\end{tabular}




\section{Sumário}

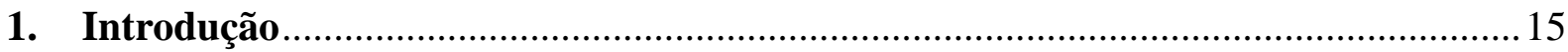

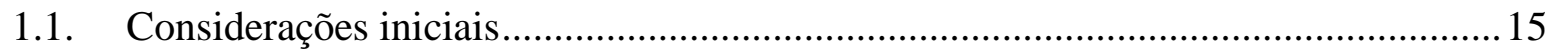

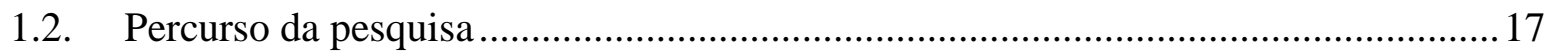

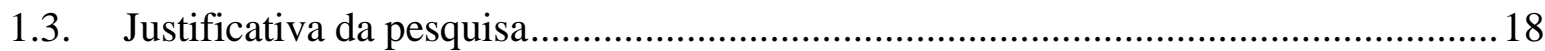

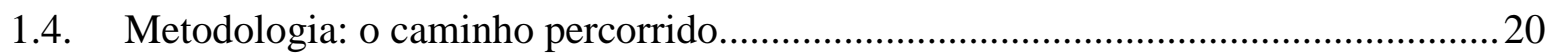

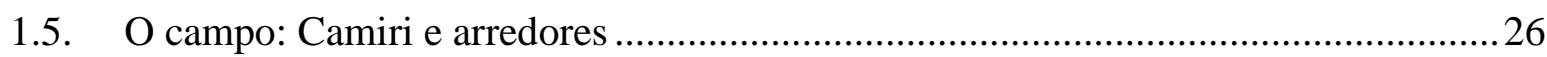

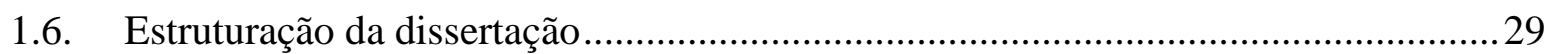

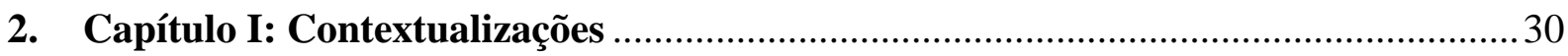

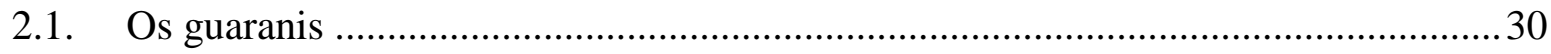

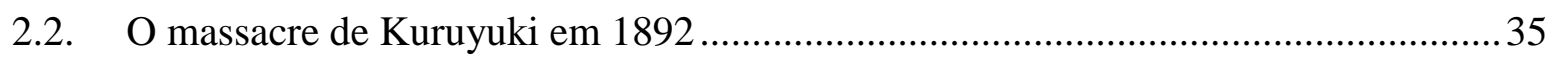

2.3. A constituição da Asamblea del Pueblo Guaraní ....................................................... 38

2.4. O movimento guarani na atualidade ................................................................. 41

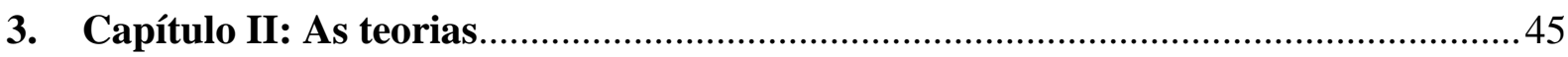

3.1. Comemorações e festas nas Ciências Sociais .......................................................... 45

3.2. A consciência nacional entre indígenas nas Américas ..........................................50

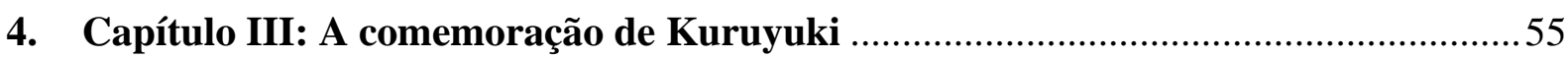

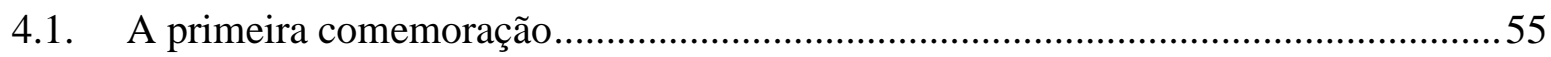

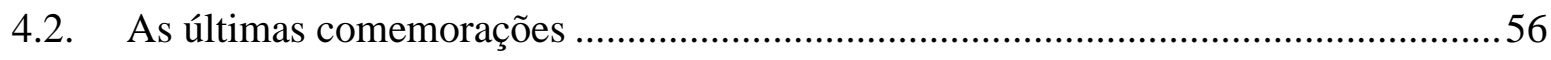

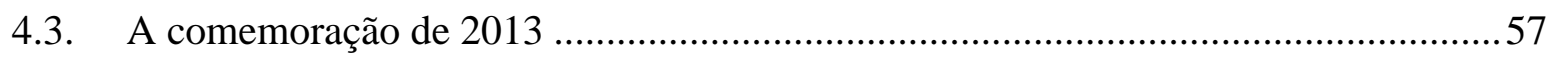

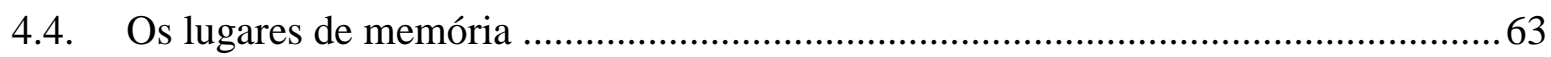

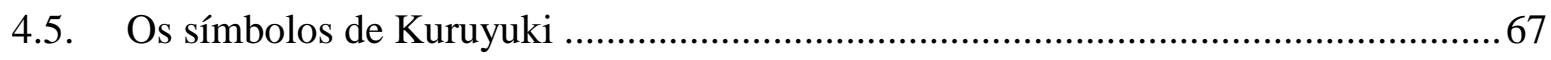

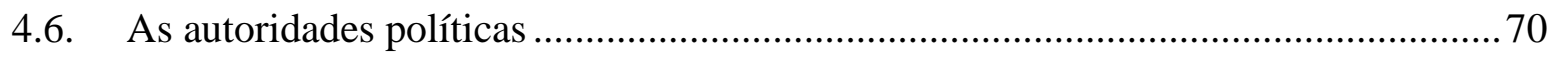

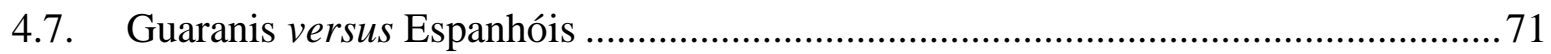

4.8. Os intelectuais da nação guarani ...................................................................... 73

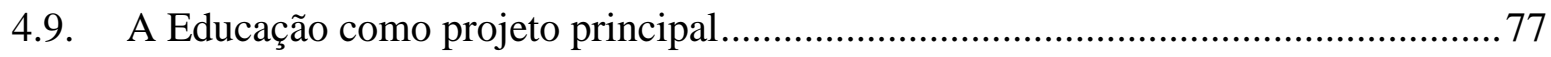

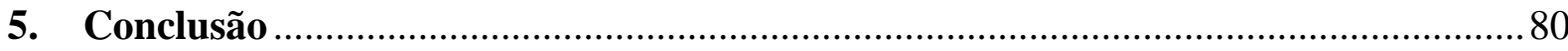

5.1. Reelaboração Cultural: História versus Cultura ……............................................... 80

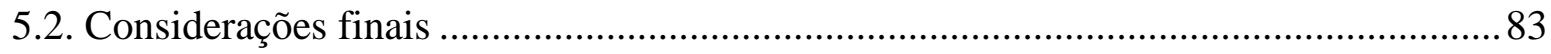

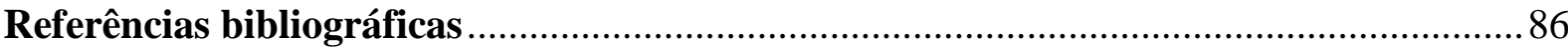

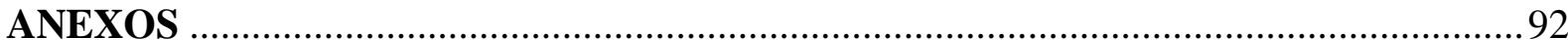




\section{Introdução}

\subsection{Considerações iniciais}

Esta dissertação tem por objetivo compreender, a partir da situação social específica da comemoração ${ }^{1}$ do massacre de Kuruyuki, o processo de nacionalização guarani no contexto do Estado da Bolívia. O estudo etnográfico aborda o significado da comemoração para os guaranis, assim como para a Asamblea del Pueblo Guaraní (APG), e como esta se apropria de um fato histórico do fim do século XIX como estratégia de construção de uma consciência de nação guarani. Uma das questões centrais diz respeito a como diferentes atores guarani (lideranças da APG, comunidades, agências de educação guarani, conselho de sábios) interpretam a comemoração.

Ao longo das últimas décadas as organizações indígenas das Américas vêm reivindicando direitos a partir de suas diferenças culturais e da interpretação das suas histórias. Segundo Lorenzoni e Follér (2011), as lutas de muitos movimentos sociais giram em torno da inclusão das vozes dos excluídos e da visibilidade daqueles que se tornaram invisíveis. No entanto, tais processos de inclusão são complexos, assimétricos e, muitas vezes, contraditórios. De certa forma, este trabalho pretende dar conta das complexidades desses processos. Nesse sentido, pergunta-se se as últimas comemorações de Kuruyuki podem ser compreendidas como mecanismo de visibilidade dos guaranis enquanto nação no âmbito do Estado Plurinacional boliviano. O que motiva, anualmente, os guaranis a celebrar Kuruyuki? Existem contradições nessas motivações? Quais?

O massacre de Kuruyuki, que aconteceu em janeiro de 1892, foi o último dentre vários enfrentamentos armados dos guaranis contra o exército boliviano. Diversos estudos (MELIÀ, 1988) e registros, desde a literatura missionária até as etnografias mais recentes, apontam o potencial guerreiro dos guaranis $^{2}$. Todavia, em Kuruyuki, aproximadamente três mil kereimbareta (guerreiros) foram assassinados pelas forças estatais, depois de resistirem a uma série de batalhas contra a usurpação de seus territórios e o estabelecimento de um regime de

\footnotetext{
${ }^{1}$ Uso o termo comemoração, em detrimento à celebração, pois é assim que os próprios guaranis se referem à Kuruyuki. Em termos teóricos, a categoria comemoração converge com os conceitos abordados neste trabalho.

${ }^{2}$ A palavra guarani vem do mesmo idioma e, etimologicamente, significa guerreiro.
} 
fazendas organizado a partir de relações de servidão e escravidão ${ }^{3}$. Mesmo com a transformação da organização social guarani, eles mantiveram sua base estrutural - i. e., a família - preservando seu idioma e seus laços de reciprocidade (MELIÁ, 1988).

Cem anos após o enfrentamento, em 1992 os guaranis se uniram para comemorar o centenário de Kuruyuki. A primeira comemoração contou com guaranis de distintas comunidades, foi organizada pela APG e por instituições locais de desenvolvimento, sendo que os discursos desse dia aludiam à solidariedade e unidade dos guaranis. Dentre vários letreiros que apareceram na multidão, destacou-se o seguinte: Muertos de Kuruyuki, surjan de sus trincheras, marchen con nosotros hacia la Tierra sin Mal ${ }^{4}$.

Anualmente, desde 1992, os guaranis se reúnem em Kuruyuki ${ }^{5}$ para celebrar o massacre do fim do século XIX. A comemoração, além de ser uma grande festa na qual familiares e amigos se encontram para conversar, dançar, beber chicha de maíz, é um encontro político, momento para anunciação pública de demandas, de benfeitorias, de projetos etc. Em 28 de janeiro de 1992, por exemplo, na homenagem ao centenário do massacre de Kuruyuki, foi implantada a campanha de alfabetização bilíngue promovida pela APG e pela Teko Guarani, sendo que esta cumpre até os dias atuais importante papel no programa de educação intercultural e bilíngue entre os guaranis.

Por último, conforme nos mostra Combès (2005a), Kuruyuki é o mito de fundação da APG. Essa organização política guarani foi visibilizada nacionalmente por meio da primeira comemoração de Kuruyuki, em 1992, e sua grande Marcha. Estes eventos são indissociáveis da Asamblea, bem como o contrário. Nesse sentido, escrever sobre a comemoração de Kuruyuki é escrever, também, sobre a APG e vice-versa.

A análise da comemoração do massacre de Kuruyuki possibilitou, em certa medida, perceber os processos de reorganização cultural a partir da apropriação da memória do massacre, observando, sobretudo, o envolvimento dos diferentes atores guaranis na

\footnotetext{
3Sobre a escravidão guarani na Bolívia, sugiro a leitura da publicação da Inter-American Commission on Human Rights (IACHR), intitulada Comunidades Cautivas: Situación del Pueblo Indígena Guaraní y Formas Contemporáneas de Esclavitud en el Chaco de Bolivia (IARCHR, 2009).

${ }^{4}$ Buscar a "Terra Sem Males" significa procurar uma terra fértil e pacífica. Essa expressão faz alusão à primeira terra da cosmologia guarani, antes do dilúvio que os levou às mazelas, gerando uma segunda terra, isto é, lugar em que existem males que vão desde a escassez da terra até a fome e doença. As consequências da conquista da América pelos espanhóis e portugueses podem ser explicadas a partir dessa cosmologia: ameaça de seus modos de ser e de viver, desapropriação de terras, a discriminação etc.
}

${ }^{5}$ Kuruyuki, originalmente, é o substantivo da localidade em que aconteceu o massacre e, portanto, o nomeou. 
consolidação de uma agenda comemorativa de um massacre cometido pelo Estado sobre os indígenas.

A cerimônia de Kuruyuki configura-se como uma situação social em que emergem distintas variáveis, que discuto ao longo da pesquisa: nação guarani, educação, direitos, autonomia indígena, território etc. Ainda, este trabalho apontará que essa situação social constituiu também um locus de revelação de desigualdades, conflitos e manipulações de regras. Deste modo, para esta proposta, a comemoração de Kuruyuki apresenta-se como uma instituição guarani polissêmica, manipulável e capaz de recobrir motivações muito diferentes.

Perguntei-me, ao longo do desenvolvimento da pesquisa, se a comemoração de Kuruyuki, enquanto apropriação do evento histórico pelos atores da APG, seria mecanismo de fortalecimento dos laços comunitários e aliança política entre os guaranis. Nessa perspectiva, a apropriação da memória da batalha é uma estratégia etnopolítica de reelaboração cultural com consequente desdobramento de um processo de nação guarani. Contudo, acredito que, mesmo sendo instrumento de afirmação de pertencimento a um grupo, existem contradições e conflitos entre os guaranis sobre como e por que comemorar esse fato histórico, assim como compreensões variadas do que seria uma nação guarani na Bolívia.

\subsection{Percurso da pesquisa}

A escolha por trabalhar academicamente com povos indígenas tem muito a ver com minha biografia: desde criança, quando passava férias na chácara de minha avó no Vale do São Patrício (Goiás) e, então, tive contato com os Tapuios do Carretão, indígenas emergentes da região. Ao vê-los, passei a me questionar como aquelas pessoas - sem os estereótipos apresentados pela escola e pela mídia - podiam realmente ser "índios". Essa foi uma das questões que me levaram a optar pelas Ciências Sociais no vestibular, em 2007, quando terminei o ensino médio.

$\mathrm{Na}$ graduação, apresentei trabalho de final de curso sobre os Tapuios, além de ter pesquisado como bolsista de iniciação científica a etno-história do massacre de Kuruyuki entre os guaranis na Bolívia. O contato com esse tema na graduação me possibilitou escrever o projeto de pesquisa de mestrado. Depois de muitas alterações na proposta, do desenvolvimento teórico e da experiência de campo, apresento este trabalho como resultado de um empreendimento investigativo de anos e com várias pessoas envolvidas. 


\subsection{Justificativa da pesquisa}

Esta dissertação está vinculada à Linha de Pesquisa Etnicidade, Raça e Povos Indígenas nas Américas do Programa de Pós-Graduação em Estudos Comparados sobre as Américas do Centro de Pesquisa e Pós-Graduação das Américas - CEPPAC/UnB. Assim como essa linha de pesquisa, este trabalho propõe abordar as iniciativas indígenas de organização política e identitária diante do processo de construção do Estado, neste caso, a Bolívia. Ademais, a pesquisa foi desenvolvida no âmbito do Laboratório de Estudos e Pesquisas em Movimentos Indígenas, Políticas Indigenistas e Indigenismo (LAEPI), um espaço de estudos e pesquisas do CEPPAC voltado para a compreensão da política interétnica dos movimentos indígenas nas Américas.

O desenvolvimento da pesquisa se deu a partir de uma perspectiva de estudo multidisciplinar entre as Ciências Sociais. Por isso, acredito que o objeto deste estudo é pluridimensional e, portanto, susceptível de ser abordado a partir de diferentes arcabouços disciplinares e conceituais. Desse modo, é a partir do diálogo da Antropologia (do entendimento dos aspectos simbólicos das relações sociais), da Ciência Política (das teorias sobre comportamento político e instituições), da Sociologia (entendimento de categorias como movimentos sociais, mudança social e sociedade civil), além da História (da compreensão e organização dos eventos sociais através do tempo) que procurei vislumbrar multidisciplinarmente meu objeto de pesquisa. Este enfoque não trata de superar o conhecimento disciplinar, mas de reconhecer a pertinência e importância de um modo alternativo de fazer ciência social, principalmente porque a realidade, na maioria das vezes, não pode ser enquadrada no domínio de uma única disciplina.

Em termos teóricos, este trabalho justifica-se pela necessidade de problematizar concepções arraigadas sobre a construção de culturas (pluri)nacionais e seus impactos locais. Debrucei-me em verificar como as comunidades e, sobretudo, a organização política guarani interagem e ressignificam os planos e as ações das políticas de (pluri)nacionalização do Estado da Bolívia, elaborando representações próprias de suas histórias.

Vale ressaltar que se trata de um tema pouco discutido no Brasil: construção de nacionalidades indígenas. No Brasil, ao contrário da Bolívia, não há contexto político para se debater as identidades indígenas a partir de processos de formação de uma consciência nacional. Além do Brasil, nos países como Argentina e Uruguai as populações indígenas configuram-se enquanto etnias, isto é, minorias étnicas com fraca conjectura para se ascender 
a espaços políticos relativamente autônomos diante do Estado. Fazer este tipo de estudo não é o mesmo que assumir que o "destino histórico" de toda e qualquer sociedade, mesmo as indígenas, seja formar Estados nacionais. Antes disso, trata-se de refletir sobre os constrangimentos que o Estado nacional exerce, certamente de modo muito variado, para a conformação de consciências étnicas indígenas, dentre elas, a consciência nacional.

Por muito tempo a tradição de pesquisa das Ciências Sociais brasileiras foi orientada pelas questões e problemáticas brasileiras, sendo relativamente pequeno o quantitativo de investigações sobre a realidade além das fronteiras nacionais. Tendo isso em vista, juntamente com a construção de uma agenda de pesquisa com conteúdo relativo a outros países, esta dissertação contribui para a crescente internacionalização das Ciências Sociais brasileiras, à medida que apliquei ferramentas conceituais desenvolvidas a partir das Ciências Sociais no Brasil para problematizar a realidade boliviana. Além do mais, busco dialogar com autores bolivianos, latino-americanos e, de modo especial, com intelectuais guaranis que produzem conhecimento científico sobre seu povo (CAUREY, 2012; ORTIZ, CAUREY, 2011). Cabe destacar, ainda, a importância de produção científica em língua portuguesa sobre os guaranis na Bolívia de modo a favorecer melhor compreensão sobre a situação política dos povos indígenas bolivianos fora do contexto andino.

Também, este trabalho justifica-se pela continuidade da investigação acerca do movimento indígena dos guaranis na Bolívia. Durante minha graduação em Ciências Sociais na UFG (2007-2010), enquanto bolsista de iniciação científica vinculado ao Projeto de Pesquisa Abordagens histórico-etnográficas das relações entre etnias e nação: Brasil e Bolívia, Século XIX - sob orientação da Professora Izabel Missagia de Mattos (UFFRJ) -, realizei levantamento bibliográfico sobre a batalha de Kuruyuki (ANDRADE, 2010, 2011). $\mathrm{Na}$ ocasião, depois de mapear o material, mostrei que existem vários registros que apontam para a ressignificação política do massacre de Kuruyuki pelos guaranis contemporâneos. A partir desse resultado, desenvolvia pesquisa sobre a comemoração de Kuruyuki no contexto de reelaboração cultural.

Por último, mas não menos importante, o desenvolvimento da proposta foi motivado para além do desejo pessoal de obtenção do título de mestre, ela se justifica, também, pela vontade e compromisso em colaborar com os guaranis na Bolívia. Espero que esta dissertação sirva como instrumento de reflexão pelos próprios indígenas e de conhecimento para elaboração de políticas públicas que atendam a suas necessidades e reivindicações, projetos de colaboração e de captação de recursos. Nesse sentido, o desenvolvimento da pesquisa foi 
orientado por valores para além dos acadêmicos, rejeitando as noções de neutralidade (mas não de imparcialidade) que já caracterizaram fortemente as ciências humanas, e reconhecendo as Ciências Sociais como um meio de colaborar com a sociedade. Essa perspectiva se aproxima ao que vem sendo chamando de antropologia colaborativa, debate que problematiza a estreita relação de envolvimento político entre o pesquisador com seus interlocutores para aprofundamento da análise do seu objeto empírico.

\subsection{Metodologia: o caminho percorrido}

A opção pela análise de um caso específico remete ao arcabouço teórico-metodológico de análise situacional, ou análise de casos detalhados. Antropólogos da Escola de Manchester, sendo Max Gluckman um dos mais expressivos, criticaram o modelo clássico da antropologia britânica, e realizaram importantes avanços metodológicos na disciplina. Gluckman, além de cientista, era ativista político decididamente anticolonial. A partir de estudos no continente africano, o objeto da antropologia não era mais o estudo de estruturas sociais isoladas ou sistemas tradicionais africanos concebidos de modo estático. A nova perspectiva estava preocupada com a mudança social entre os grupos locais na África provocada pelo projeto colonial. Uma das contribuições dessa Escola foi o desenvolvimento metodológico do estudo de caso detalhado, envolvendo análise de situações pontuais de interação social para inferir regras das dinâmicas de uma estrutura social. Nesse sentido, Gluckman e seus pares colocaram em questão o paradigma estrutural funcionalista, principalmente as questões relacionadas às situações de conflito e competição que esse paradigma não contemplava.

Dentre suas importantes contribuições para as Ciências Sociais, o clássico Análise de uma situação social na Zululândia moderna, de Gluckman (1987), discute o conceito de conflito e o método de análise de situação social. Esses estudos foram gestados a partir de pesquisas realizadas na região da Rodésia do Norte (atual Zâmbia), no sul do continente africano. Existe grande tendência de operacionalização das análises detalhadas em estudos com foco em um único evento claramente demarcado no tempo e no estado, um evento específico. Assim, Gluckman aplicou esse conceito na Zululândia.

Segundo Gluckman (1987), "situação social é o comportamento, em algumas ocasiões de indivíduos como membros de uma comunidade, analisando e comparando seu comportamento em outras ocasiões" (p. 287). Partindo dessa premissa, Gluckman analisa a inauguração de uma ponte na Zululândia como uma situação social que explica as relações 
entre brancos europeus, negros zulus e uma diversidade de outras etnias europeias e africanas postas em conjunção. $\mathrm{O}$ autor demonstra, por meio da análise de situação social descrita, como a estrutura da época pode ser analisada como unidade operacional; a existência colaborativa de dois grupos raciais dentro de uma comunidade constitui a forma predominante de uma estrutura. Isto é, Gluckman (1987) percebeu na cooperação eventual entre zulus e europeus, apesar das contradições, uma evidência de que constituía "uma única comunidade com modos específicos de comportamento" (GLUCKMAN, 1987).

A partir do aporte metodológico acima mencionado, tentei entender a comemoração do massacre de Kuruyuki a partir do modelo de análise de situação social. Essa escolha teórico-metodológica permite, a partir das situações sociais e de suas inter-relações em uma sociedade particular, abstrair a estrutura social e as relações sociais, compreendendo o contexto e as especificidades dos grupos sociais e étnicos envolvidos. Também, a noção de situação social é vantajosa para analisar, a partir do acontecimento da celebração de Kuruyuki, a interação entre diferentes atores e agências culturais, além da configuração das relações políticas.

Velsen (1987) compreende a análise de uma situação social (GLUCKMAN, 1987) como método de "coleta de um tipo especial de informações detalhadas" (VELSEN, 1987, p. 345). De acordo com o autor, essa opção metodológica influi não somente no enfoque de observação dos dados, mas também em sua análise, vinculando o conflito como parte integrante do processo social. O método, na abordagem de situação social, possibilita entender as opções realizadas pelas pessoas em uma determinada situação, bem como a regularidade e variedade das ações.

A partir dessa perspectiva teórico-metodológica, conduzi minhas observações em campo, tanto na observação e interpelação do que é produzido nos eventos destinados à lembrança do massacre quanto nas conversas com os guaranis.

Fui duas vezes a campo. Fiz um primeiro campo exploratório de três semanas em janeiro e fevereiro de 2013. A segunda ida ocorreu nos meses de agosto e setembro do mesmo ano, com mais 40 dias, aproximadamente, em Camiri e Santa Cruz de la Sierra. A segunda ida a campo ocorreu fora da agenda de Kuruyuki (que ocorre sempre em janeiro), todavia, procurei trabalhar com as memórias das comemorações e, sobretudo, com a organização política. 
Em campo, procurei exercer especial atenção às conversas com as bases do movimento indígena guarani, tentando encontrar versões para além da "oficial", difundida pela organização. Na minha primeira incursão, pude notar descontentamento/conflito das bases do movimento em relação às alterações da programação da $121^{\mathrm{a}}$ comemoração, ocorridas devido à agenda do presidente Evo Morales. Essa foi minha primeira situação em campo que me fez despertar para o discurso implícito, isto é, aquilo que não nos dizem "formalmente", porém contribui para compressão das relações dos nossos interlocutores.

Além dos dados das observações de campo, foram considerados também os seguintes para a realização desta dissertação: 1) entrevistas semiestruturadas com integrantes e exintegrantes da organização indígena e, também, com representantes de ONGs ${ }^{6}$ indigenistas que atuaram na construção da APG; 2) conversas com guaranis nas comunidades, as bases do movimento social; 3) publicações em periódicos - alguns jornais locais - de 1992 até 2013, sobre a celebração de Kuruyuki; 4) vídeos produzidos por indigenistas e indígenas sobre as comemorações anteriores (inclusive a gravação de alguns discursos políticos em Kuruyuki, seja de mburuvicha ou de karai); 5) notas da observação do espaço e dinâmica da celebração dos 121 anos do massacre, ocorrida entre os dias 27 e 29 de janeiro de 2013; 6) documentos, textos e outros materiais produzidos por ONGs que apoiam a celebração; e 7) referências bibliográficas. Como tive de lidar com diferentes discursos (lideranças, base do movimento, sábios etc.), me ative para não tomar os discursos dos meus diferentes atores como mera realidade. As falas e os discursos dos meus interlocutores foram apenas um dos elementos para discussão e análise da realidade que proponho pesquisar.

Minha aproximação às pessoas do campo de pesquisa foi feita por meio de contatos cedidos por dois interlocutores pesquisadores que também trabalham com os guaranis na Bolívia, sendo um deles a principal referência bibliográfica para a discussão empírica deste projeto: a etno-historiadora francesa Isabelle Combès. Ela possui larga experiência de pesquisa entre os povos indígenas das terras baixas na Bolívia, já tendo vivido em território guarani. O outro interlocutor é Mathiel da Silva, que defendeu sua dissertação sobre a historiografia do massacre de Kuruyuki no Programa de Pós-Graduação em História da Universidade Federal de Grande Dourados (UFGD). Conheci esse pesquisador no II CIAEE Congresso Iberoamericano de Arqueologia, Etnologia e Etno-história ${ }^{7}$ - na cidade de

\footnotetext{
${ }^{6}$ Apoyo Para el Campesino-Indígena del Oriente Boliviano (APCOB), Confederación de Pueblos Indígenas de Bolivia (CIDOB) e Centro de Investigación y Promoción del Campesinado (CIPCA).
}

${ }^{7} \mathrm{Na}$ ocasião, apresentei parte do desenvolvimento desta pesquisa, ANDRADE (2012). 
Dourados em Mato Grosso do Sul. A interlocução com essas duas pessoas foi um importante caminho a fim de angariar contatos locais para a primeira viagem a campo.

Os guaranis na Bolívia são um dos povos indígenas mais numerosos da parte oriental boliviana, com uma população de 58.990 pessoas (de acordo com o último Censo de 2012). Nesse sentido, foi fundamental fazer um recorte espacial para o estudo. Trabalhei na APG Nacional em Camiri, mas também tive a oportunidade de interagir em uma das suas regionais, a Capitanía de Kaami, responsável pela política guarani em Camiri e seus arredores.

Em trabalho de campo exploratório ${ }^{8}$, durante minha primeira ida a campo na Bolívia, além da minha familiarização ao contexto da pesquisa, visitei museus e ONGs a fim de coletar materiais primários e bibliografias, participei da $121^{\mathrm{a}}$ comemoração de Kuruyuki - nos dias 27 e 28 de janeiro na Comunidade de Ivo (departamento de Chuquisaca) -, estabeleci contato com alguns mburuvicha (liderança guarani), além de construir relação de proximidade com o arakuaaiya Antonio Méndez. Trata-se de uma preciosa indicação de Isabelle Combès. Mendéz vive em Camiri, cidade onde fica a sede da APG, e se dispôs a me acompanhar em várias visitas que realizei em Camiri (APG, Teku Guarani, CIPCA, Consejo Educativo del Pueblo Originario Guaraní etc.).

O retorno a campo me permitiu fazer novos contatos, além de restabelecer os já assumidos. Fixei-me por volta de 40 dias (10 de agosto até dia 20 setembro) no território guarani. Com a ajuda de um dos meus interlocutores-chave, o arakuaaiya Antonio Méndez ${ }^{9}$, aluguei um quarto no sobrado de uma senhora não indígena. Este estava localizado no centro da cidade de Camiri, o que me permitia maior interação com as lideranças indígenas da região. Como vou apresentar adiante, Camiri é uma cidade com muitas referências guaranis.

Na segunda incursão no campo, retomei contato com Antonio, porém ele estava um pouco debilitado, devido a uma doença. Assim, aproveitei esse afastamento para conhecer e estabelecer novas relações. Foi quando, em setembro, conheci Felipe Román, outro sábio guarani. Desde então, estive quase todos os dias restantes com Felipe. De Camiri viajamos

\footnotetext{
${ }^{8}$ Minha primeira ida a campo durou duas semanas. Do dia 20 janeiro até o dia 5 de fevereiro de 2013 estive na cidade de Santa Cruz de la Sierra e Camiri no departamento de Santa Cruz e na Comunidade de Ivo no município de Macharetí, departamento de Chuquisaca, onde aconteceu a celebração dos 121 anos do massacre de Kuruyuki.

${ }^{9}$ Antonio Méndez, originalmente, é da Capitanía del Alto y Bajo Isoso, porém, atualmente, vive na cidade de Camiri, Capitanía Kaami, onde é presidente da Fundación Yeporaka Centro de Investigación Antropológica Guaraní. Méndez já acompanhou o trabalho de campo de vários cientistas sociais em Território Guarani na Bolívia.
} 
para Ivo e Kuruyuki a fim de que ele, enquanto sábio e cofundador do evento, pudesse me mostrar os espaços da comemoração.

Além da presença diária na sede da APG Nacional em Camiri, aproveitei minha segunda ida a campo para me aproximar de alguma comunidade guarani. Nesse sentido, me apresentei à APG Zonal ${ }^{10}$ de Kaami, também em Camiri, e propus ao presidente que conversássemos com uma escola de alguma comunidade para que eu pudesse ministrar aulas de reforço de matemática para crianças guaranis. A ideia era oferecer algum trabalho voluntário para que a partir daí pudesse estabelecer contato com as pessoas em suas casas, isto é, no dia a dia na comunidade, fora do espaço de política institucional guarani. Em campo, percebi que estreitar essa relação demandaria mais tempo que o programado em campo. De qualquer forma, minha experiência com aulas de reforço para crianças guaranis na escola de Itanambikua, onde fui apresentado pelo presidente da APG de Kaami, foi importante para o desenvolvimento do meu campo. Assim, minha experiência não se limitou apenas às lideranças ou aos sábios guaranis, mas abarcou, também, relações com as pessoas fora dos espaços institucionais da política guarani, na comunidade.

Apesar de conversar com várias pessoas nas comunidades, ao final, meu campo teve caráter eminentemente institucional, uma vez que me ocupei, na maior parte do tempo, na APG, além de visitas à escola indígena de Itanambikua, a ONGs como Teku Guarani, CIPCA, e conversas com interlocutores-chave na cidade de Santa Cruz de la Sierra e Camiri. Encontrei-me com representantes dessas e outras ONGs que trabalham ou já trabalharam com os guaranis no contexto de Kuruyuki, conversamos informalmente, me apresentei e contei minha proposta de pesquisa. Além disso, passei cinco dias na Hemeroteca do Museu de História da Universidad Autónoma Gabriel René Moreno levantando notícias sobre a comemoração. Elegi os três mais importantes jornais da região (La Estrella del Oriente, El Deber e Diario El Día) e pesquisei em cada impresso dos dias 22 de janeiro a 3 de fevereiro de 1992 até 2012 notícias sobre Kuruyuki. Encontrei um rico material que me permitiu analisar os aspectos empíricos de cada comemoração.

Estive alguns dias, da primeira e da segunda vez em campo, na cidade de Santa Cruz de la Sierra para conversas com representantes de ONGs (CIPCA, APBOC, CEJIS, CIDOB),

\footnotetext{
${ }^{10}$ Conforme veremos mais adiante, a política guarani é dividida em três níveis: a APG Nacional, as APGs zonais, isto é, as capitanias e, por sua vez, cada capitania é composta por várias comunidades, APG Comunal.
} 
esses, de alguma maneira, já estiveram envolvidos em alguma edição da comemoração guarani.

O caráter institucional do trabalho de campo privilegiou a atuação nos espaços previamente estabelecidos para a política guarani, além de ONGs indigenistas. Em suma, o discurso "oficial" ou "público para fora" foi meu foco. Isso se justifica pelo fato de que são essas agências e agentes quem mais articulam ideologicamente o discurso da "nacionalidade" ou que, pelo menos, são obrigados a lidar com esse discurso.

Durante a realização da pesquisa de campo utilizei gravadores e câmera fotográfica, considerando preceitos éticos da pesquisa e de contextos em que eram permitidos. Além disso, usei outros recursos de registro, como a escrita no caderno de notas e diário de campo. Também, coletei material de divulgação e informação sobre a comemoração, produzido pela APG ou por periódicos locais. Assim, as entrevistas semiestruturadas, conversas informais, observações, vídeos e documentos sobre as comemorações do massacre de Kuruyuki compuseram a base empírica sobre a qual as análises foram feitas.

Os dados primários pertinentes, depois de coletados, foram agrupados de acordo com a importância para o objetivo da pesquisa e sua repetição. Depois, produzi um quadro de informações empíricas relacionando-as com determinados eixos teóricos temáticos, construindo argumentos no texto dissertativo.

Por último, em relação à metodologia, destaco algumas das dificuldades enfrentadas no desenvolvimento do projeto de pesquisa desta dissertação. Em campo, não tive dificuldades em me comunicar em espanhol com os guaranis das organizações políticas e nos contextos urbanos de modo geral, porém tive certos embaraços ao me relacionar com as pessoas nas comunidades rurais, como Itanambikua ${ }^{11}$, comunidade próxima à Camiri, na qual estive diversas vezes em sua escola ${ }^{12}$ para dar aulas de reforço de matemática para crianças guaranis. Nestes contextos, assim como eu, muitos guaranis também não tinham o espanhol como língua nativa. Eles aprendiam como primeira língua e comunicavam-se em guarani nos

\footnotetext{
${ }^{11} \mathrm{~A}$ comunidade de Itanambikua está localizada no município de Camiri, a aproximadamente $8 \mathrm{~km}$ da praça principal da cidade. O rio Parapetí separa a comunidade rural do centro urbano, todavia, pela proximidade, os guaranis de Itanambikua estão profundamente atrelados à vida em Camiri: lá trabalham, comercializam e estudam. Optei por frequentar essa comunidade justamente por ser a mais próxima de Camiri, onde está a sede da APG Nacional e a APG Zonal, Capitania de Kaami, que representa a comunidade de Itanambikua.

${ }^{12}$ A escola denominada Unidad Educativa Central Juan Pablo Rivero está localizada na parte central da comunidade de Itanambikua, próxima às margens do rio Parapetí. A escola surgiu a partir de um Núcleo Escolar Campesino e atualmente é uma escola indígena guarani vinculada ao governo de Camiri.
} 
espaços domésticos, já nos lugares públicos, usavam o espanhol, como na escola. Além disso, eles dominavam pouca a forma padrão do idioma. Infelizmente, ainda não tive a oportunidade de estudar a língua guarani, apesar de ter aprendido alguns vocabulários, principalmente as categorias identitárias.

Todavia, em campo, muitas das situações que envolviam minha diferença linguística e nacionalidade foram convertidas em elementos positivos para a interação. Até porque, de modo geral, minha brasilidade despertava alguma curiosidade nos bolivianos, incluindo, obviamente, os guaranis. Santa Cruz de la Sierra é uma cidade com bastante brasileiros, porém, Camiri, não. Essa curiosidade se dava no interesse em comentar comigo algum tema relativo ao Brasil, sendo que, na maioria das vezes, conversávamos descontraidamente sobre futebol, músicas, novelas da TV Globo que são transmitidas em uma versão dublada para espanhol, a presidenta Dilma Rousseff etc. Nesse sentido, as controvérsias por eu ser de outro país foram facilmente convertidas em estratégias de aproximação das pessoas no campo. Assim, falar sobre os estereótipos da cultura nacional do pesquisador constituía, por meio da reciprocidade da interação, um bom ensejo para conhecer o modo de ser guarani, bem como a bolivianidade daquelas pessoas.

Outra dificuldade na execução do projeto da dissertação diz respeito à impossibilidade de concentrar meu trabalho de campo em torno da data do evento, isto é, em janeiro e fevereiro de 2013, quando fiz minha primeira ida à Bolívia, em função da pesquisa. A proposta inicial previa minha presença em Camiri a partir dos primeiros dias de janeiro, para participar da organização do evento e, consequentemente, estar mais inteirado do desenvolvimento da comemoração. Contudo, devido à alteração do calendário de aulas da UnB - por conta de uma greve em 2012 -, eu estava cursando três disciplinas no mestrado. Assim, fiquei apenas duas semanas no começo do ano e voltei a partir de agosto, quando já havia concluído todas as disciplinas do curso de mestrado.

\subsection{O campo: Camiri e arredores}

Podemos dizer que a Bolívia é dividida em duas grandes regiões culturais bem distintas. Nas terras altas andinas - parte ocidental - predominam as culturas quéchuas e aimarás, respectivamente, 1.281.166 e 1.191 .135 pessoas (INE, 2012). Frequentemente, as representações em torno desse país se dão a partir de elementos apenas das culturas andinas, quéchuas e aimarás, sobretudo, no segmento turístico visto desde o Brasil. Do outro lado - o 
oriental - temos as terras baixas com predomínio dos guaranis e chiquitanos, respectivamente, 58.990 e 87.885 pessoas (INE, 2012). A capital econômica e política desta região é a cidade de Santa Cruz de la Sierra. Nas idas ao campo, sempre cheguei pelo aeroporto desta cidade. De lá partia de ônibus para Camiri, 307 km ao sul, em direção à cidade de Yacuíba, fronteira com Argentina. De Camiri, sede do movimento guarani, seguindo mais $58 \mathrm{~km}$ na mesma rodovia (Ruta 9), também em direção sul, chegamos à região da comunidade de Ivo e Kuruyuki, nas margens do rio Cuervo, onde ocorreu esse comemora Kuruyuki (Figura 1).

Camiri, Kaami em guarani, é a capital da província de Cordillera do departamento de Santa Cruz, sua população é de aproximadamente 33 mil habitantes (INE, 2001). Já a província conta com a superfície de $86.245 \mathrm{~km}^{2}$ e por volta de 120 mil habitantes. Dentro deste território coabitam brancos, mestiços e guaranis. Os dois primeiros estão presentes em diferentes povoados, enquanto que os guaranis se concentram majoritariamente em comunidades localizadas no sudoeste da província, região do rio Parapetí.

O imaginário social de Camiri, bem como da maioria do oriente boliviano, é fortemente permeado por aspectos da cultura guarani. Como eles próprios afirmam: trata-se do tradicional "território guarani". Nomes de ruas, rios, lugares, objetos e comidas são de origem guarani. Também, percebe-se na cidade a presença de ONGs indigenistas e das próprias instituições indígenas (APG Nacional e Zonal, Teku e CEPOG). Na região, existem prefeituras indígenas e, em Camiri, alguns distritos indígenas. Cotidianamente, vê-se caminhonetes e ambulâncias das entidades guaranis pelas ruas. Além disso, existem estátuas dos líderes guaranis em praças públicas e uma agenda comemorativa de massacres e morte de guerreiros em enfrentamentos. Posteriormente abordarei a comemoração da morte do líder Apiaguaiqui Tumpa em Monteagudo.

Por outro lado, Camiri é a capital petroleira da Bolívia, é fortemente marcada por aspectos relacionados à produção do petróleo. Inclusive, sua fundação em 1935 e estabelecimento atual como a cidade mais rica e mais populosa do chaco boliviano só foi possível a partir do desenvolvimento da economia petroleira.

A Standard Oil Company, empresa estadunidense de produção, transporte e refino de petróleo, começou sua exploração, em 1924, em Bermejo, extremo sul da Bolívia. Logo, avançou para o norte, instalando-se em 1927 na região de fazendas que atualmente é Camiri. Definitivamente, a chegada da petroleira na região foi responsável por grandes mudanças sociais: a atração de imigrantes nacionais e estrangeiros, sobretudo, muitos guaranis da 
província de Cordillera e do departamento de Chuquisaca. Por questões tributárias, a Bolívia conquistou a concessão das instalações da Standard, constituindo, assim, em 1937, a Yacimientos Petrolíferos Fiscales Bolivianos (YPFB), empresa estatal. Em 1954, o país se tornou autossuficiente em petróleo.

Além do petróleo, a pecuária é outra importante atividade econômica do Chaco como um todo. No entanto, devem-se diferenciar pequenos e grandes produtores. Os poucos grandes fazendeiros, donos das terras e meios de produção, que escravizavam a mão de obra guarani, dedicam-se à criação, quase que exclusiva, de bovinos. Já entre os pequenos produtores, indígenas ou camponeses, a maioria da população rural, predomina a produção pecuária de pequeno porte: cabras, porcos e galinhas.

Por último, em terceiro, a prestação de serviços é um setor que está fortalecendo na cidade, em decorrência, em certa medida, dos recursos provenientes das petroleiras. Nos últimos anos instalaram em Camiri: bancos e entidades financeiras, hotéis, restaurantes, farmácias, comércio de modo geral. Nesta atividade, muito dos trabalhadores do comércio informal de Camiri são guaranis. Eles vendem alimentos, artigos importados, roupas etc.

Na Bolívia, os guaranis estão nas províncias de: Cordillera em Santa Cruz, Luis Calvo e Hernando Siles em Chuquisaca e Burdet O'Connor e Gran Chaco em Tarija, constituindo o território guarani. Segundo classificação do Instituto Nacional de Reforma Agraria (INRA) da Bolívia, os guaranis se encontram em 15 dos 17 Territorios Indígena Originario Campesinos (TIOC). Sendo que os outros dois são: um dos tapietés ${ }^{13}$ e outro dos weenhayeks, respectivamente de famílias tupi-guaranis e mataco-guaicurú. Nos 15 TIOC guaranis - Alto Parapetí, Charagua Norte, CharaguaSur (Parapitiguasu), Iupaguasu, Kaaguasu, Kaami, Takovo Mora, Isoso, ItikaGuasu, KaipependiKarovaicho, Tentayapi, Huacareta, Zona Ingre, Zona Macharetí e Itikaraparirenda - algumas áreas são tituladas e outras apenas demandadas. O trabalho de campo para esta dissertação foi desenvolvido no TIOC de Kaami - onde está a cidade de Camiri e a comunidade de Itanambikua e, também, no TIOC de Zona Macharetí, onde estão localizadas as comunidades de Ivo e Kuruyuki nas quais estive em janeiro para a comemoração e em visita em agosto de 2014 com Felipe Román.

\footnotetext{
${ }^{13}$ Os tapietés têm forte influências culturais dos guaranis, linguistas e, sobretudo, devido às migrações guaranis no Chaco.
} 


\subsection{Estruturação da dissertação}

A presente dissertação está dividida em três capítulos, além desta introdução e da conclusão: Contextualizações; As teorias; A comemoração de Kuruyuki.

O Capítulo I, denominado "Contextualizações”, objetiva esclarecer o leitor em relação ao objeto desta dissertação, a partir de suas contextualizações empíricas. Por sua vez, os contextos apresentados giram em torno dos guaranis na Bolívia, da história do massacre de Kuruyuki em 1892 e a constituição e cenário atual do movimento indígena guarani a partir da Asamblea del Pueblo Guaraní.

O Capítulo II, chamado "As teorias", discute as perspectivas teóricas adotadas neste trabalho. Primeiramente, discuto as comemorações no âmbito das Ciências Sociais a partir da literatura durkheimiana sobre festas e do debate acerca da relação entre a história e as percepções e representações sobre o passado, a memória. Em segundo, problematizo a construção nacional, protagonizada por indígenas, como expressão étnica. Ao final, é necessária a aproximação com o debate sobre movimento indígena.

O Capítulo III, intitulado “A comemoração de Kuruyuki”, é o central deste trabalho, é a parte em que apresento as principais ideias e resultados defendidos nesta dissertação. Nele, discuto as características do processo de construção nacional guarani a partir da comemoração de Kuruyuki. Por sua vez, este processo é defendido a partir explanação sobre o evento de 2013, dos seus lugares de memória e dos seus símbolos nacionais construídos, do papel da educação e dos intelectuais indígenas, além de uma situação específica da relação atual dos guaranis com os espanhóis.

Finalmente, na conclusão, apresento breve discussão sobre o uso do passado histórico como forma de reelaboração cultural, questão que perpassa os resultados. 


\section{Capítulo I: Contextualizações}

\subsection{Os guaranis}

Os guaranis são um dos povos mais conhecidos da história das Américas. Na Bolívia, é o mais numeroso depois dos quéchuas e aimarás. No período colonial, foi um dos principais obstáculos que os espanhóis enfrentaram para invadir a região do Chaco. Proveniente do tronco linguístico tupi-guarani do Amazonas, se dispersou pela América do Sul entre os séculos XV e XVI, estando presente, atualmente, no Brasil, Paraguai, Bolívia e Argentina.

Algumas das comunidades guaranis no território boliviano também são conhecidas como chiriguano, sobretudo no passado. Às vezes, ainda, o termo chiriguano cede lugar às denominações de seus subgrupos regionais: os izoceño e os avá. Chiriguano é uma categoria pejorativa, que é mais usada por pessoas fora do grupo. Eles se autodenominam guarani. O izoceño é um dialeto chiriguano falado por descendentes dos indígenas chanés, originalmente falantes de língua aruak. Por sua vez, os izoceño são considerados aruak-chanés guaranizados (COMBÈS; VILLAR, 2007).

Tradicionalmente, o nãnderekó - modo de ser - dos guaranis é caracterizado pela reciprocidade, princípio que rege a convivência cotidiana. Entre os guaranis na Bolívia, a economia de reciprocidade se manifesta de modo pleno nas festas. Além da festa cívica de comemoração do massacre de Kuruyuki, os guaranis solenizam o Arete Guasu, literalmente a "festa grande". Esta é uma festa típica de celebração da colheita do milho e do fim do ano agrícola. Com a colonização, por influência dos missionários jesuítas, a festa foi adaptada ao calendário cristão e a partir de então é conhecida como a festa de carnaval guarani (MELIÁ, 1997).

Os guaranis foram retratados na literatura antropológica como um dos povos mais importantes das Américas, em termos de resistência à colonização. Eles conseguiram conter vários séculos de constante pressão simbólica e física que visavam roubar seu território. Inclusive, nesse contexto, devido à belicosidade guarani, a Coroa espanhola chegou a declarar guerra a esse povo. Este fato histórico teve repercussões recentes entre os guaranis. Abordarei mais detalhadamente essa questão no Capítulo 3. Também, no período histórico anterior ao colonial, o enfrentamento guarani em defesa de seu território foi responsável por barrar a expansão imperialista inca para o sul da América do Sul, tradicionalmente território guarani. 
Apesar da resistência à administração espanhola, os guaranis acabaram reduzidos. Primeiramente, pelo empreendimento missionário e pelos donos de terras espanhóis. Depois, já durante o período republicano, os criollos invadiram o território guarani para criação de gado. De acordo com Combés (2005a, p. 240), "más que por las armas fue por vaca (la instalación progresiva de los colonos y de las haciendas) que se conquistó tardíamente, la Cordillera chiriguana".

Além das missões e dos fazendeiros, o Estado também se encarregou de tomar as terras indígenas. $\mathrm{O}$ exército daquele país massacrou milhares de guaranis só em Kuruyuki, um dentre inúmeros outros enfrentamentos. O Estado da Bolívia perdeu várias guerras para outros países (Guerra do Pacífico, Guerra do Chaco), mas ganhou diversas sobre seus povos indígenas (Karitati, Yuki, Murukuyati e Kuruyuki, só entre os guaranis).

Proveniente de áreas geográficas do Paraguai, do nordeste argentino e do sul do Brasil, os guaranis se dispersaram pelo que hoje é o território boliviano. Segundo Meliá (1988), a ocupação guarani na Cordilheira boliviana é anterior à chegada dos europeus. Várias são as explicações para a migração desse povo. Primeiramente, registros arqueológicos sinalizam que os guaranis, por conta da demanda de solos específicos para sua prática agrícola, necessitavam frequentemente de novas bases econômicas. Contudo, essa hipótese foi derrubada, pois a região do Chaco é super árida. Com isso, Metraux (1939) esboça outra explicação. Diz-nos que os guaranis se moveram em busca de minérios que serviam como moeda de trocas. Essa segunda versão também é questionada, pois naturaliza a expansão territorial associando-a ao "avanço" econômico, perspectiva bem capitalista.

Assim, talvez a versão mais recorrente e aceita na literatura é a sustentada pela própria teoria guarani. Esta visão defende a migração guarani a partir da constante busca pela Terra Sem Mal. Assim, as migrações guaranis ocorreram, fundamentalmente, por conta da busca da "Terra Sem Mal", isto é, a procura por terras produtivas para agricultura e, mais tarde, fugindo da sociedade ocidental devido a suas frentes de expansão econômicas e conflitos armados inerentes ao processo de colonização.

A teoria guarani da Terra Sem Mal, iva marei, explica sua tradicional relação com o território, justificando, assim, sua persistente resistência às ofensivas coloniais. Para os guaranis, seus territórios estão intimamente relacionados às suas cosmologias, à sua produção e, consequentemente, às suas relações de reciprocidade, três características fundamentais para 
compreender a cultura guarani. Conforme também veremos no Capítulo 3, terra e território são a principal pauta da comemoração de Kuruyuki.

De modo geral, a literatura etnológica acredita em duas frentes geográficas de penetração guarani no que hoje é a Bolívia. Uma, a partir da Chiquitania, região brasileira do Estado de Mato Grosso, outra a partir do Chaco da província de Tarija, próximo à região da fronteira com o Paraguai e Argentina. Isso explica as diferenças culturais, de dialetos e da língua guarani existentes entre esse povo na Bolívia. Aqui, é importante sinalizar que tenho consciência de que "guarani" é uma categoria genérica que abarca diferentes aspectos etnológicos (canés, isossonos, avá), que, muitas das vezes, são contraditórios e conflitantes. Porém, como este trabalho se debruça sobre a construção de uma nação guarani, é a partir deste termo identitário que proponho a discussão.

Os chiriguanos, como eram referenciados, foram responsáveis por dominar os chané, que são da família linguística arawak. Estes se constituíram como vítimas do canibalismo ritual, e também do que Combès (2005b) chama de canibalismo social. Esta categoria pretendia dar conta do processo de guaranização da língua e dos costumes chané. Todavia, observa-se um processo inverso, em que os guaranis também incorporaram práticas e elementos culturais dos chanés, a exemplo de algumas máscaras do carnaval guarani.

Ainda, segundo Combès (2005b), houve a incorporação da estrutura de organização social assimétrica chané, distinguindo-se claramente entre "chiriguanos", autodenominados de avá e, por outro lado, os escravos, os chanés que eram denominados de tapii o tapuy. Nesse sentido, os guaranis ocuparam a posição da antiga elite chané. Adotaram uma estrutura hierárquica prévia, porém em prol dos objetivos guaranis (COMBÈS, 2005b, p. 60). Assim, de acordo com perspectiva avá-guarani, os chanés eram subservientes, diferentes deles, que eram selvagens.

Em relação ao canibalismo ritual sobre os chanés, Saignes (1990, p. 23) explica que essa prática sucumbiu no começo do século XVI, quando eles passaram a ser destinados fundamentalmente para trabalhos agrícolas. Além de passarem a engrossar o número de "soldados" guerreiros avá-guarani.

As histórias e culturas tupi-guaranis foram objetos de estudos do casal de antropólogos franceses Pierre e Hélène Clastres. Em A sociedade contra o Estado, Pierre Clastres (2003) defende a ideia de que determinadas sociedades ameríndias apresentam mecanismos para precaver a emergência de um poder político segregado, o Estado. Isso não quer dizer que elas 
sejam sociedades "sem" Estado, mas antes "contra o Estado". As sociedades guaranis são fundadas em uma recusa constante ao modelo político coercitivo, elas se definem ontologicamente pelas relações de trocas recíprocas.

Hélène Clastres (1978), em seu livro A terra sem mal: o profetismo tupi, identificou um desses mecanismos de recusa do Estado a partir da manifestação religiosa denominada "profetismo"; isto é, fenômeno fundamentado em um impulso de evasão, uma procura por novos territórios frequentemente denominados "Terra sem Mal". Esta, para a autora, constitui uma forma aprofundada de como uma manifestação religiosa pode se converter em um mecanismo de resistência ontológica e política. Nesse sentido, o profetismo, como uma espécie de messianismo indígena, se constitui em um mecanismo primordial para prevenir a emergência de um aparelho de Estado. O profetismo é resultado da incansável contradição entre poder político e poder religioso. Entre os guaranis é comum a figura do líder messiânico. O grande guerreiro do massacre de Kuruyuki, Apiaguaiki, era um líder messiânico. Abordarei essa questão na próxima seção deste capítulo.

Diante do exposto, o povo que hoje se autodenomina guarani na Bolívia é resultado de constantes migrações e misturas realizadas, obviamente, desde antes da invasão europeia. A razão dessa mobilidade, segundo eles mesmos, seria a busca da Terra sem Mal. Por sua vez, essa filosofia constituiu um dos aspectos mais evidentes do povo guarani: a luta pelo território. Este trabalho, em certa medida, nos ajuda a compreender a criatividade dos guaranis ao promover, a partir da APG, a comemoração de um massacre como instrumento político para se diferenciar, recontar sua história e reivindicar direitos.

Além da concepção de iva marei, Terra sem Mal, nãnderekó é outra ideia importante para compreender a teoria guarani. Essa nos diz acerca dos "autênticos" (de acordo com eles mesmos) aspectos culturais guaranis, isto é, sua forma de ser no mundo. Esses dois princípios éticos guaranis se interceptam porque a terra boa para se viver, produtiva e tranquila é onde os guaranis podem viver em plenitude, de acordo com seu nãnderekó. Nesse sentido, as noções de terra e território guaranis estão vinculadas diretamente aos seus aspectos produtivos, a preservação do meio ambiente, bem como a manutenção de uma identificação comum. Para Albó (2009), os guaranis imprimem um profundo significado da ideia de território na sua cultura.

Es mucho más que la tierra para cultivo y/o pastoreo. Puede referirse también a esto pero implica además todo un conjunto que abarca bosques, 
vertientes, ríos, flora y fauna de los que se vive, con los que se convive y por los que se va transitando (idem, p.13).

A profunda relação que os guaranis estabeleceram com seus territórios fez com que estes lutassem constantemente em defesa de suas terras. Ao longo do tempo, enfrentaram o império inca, os colonizadores espanhóis, fazendeiros mestiços. Em 1825, com a constituição da República da Bolívia, a situação não mudou. Nesse contexto político, o Estado, com respaldo militar republicano, permitiu que os fazendeiros expandissem suas fronteiras econômicas invadindo o território guarani. Assim, durante o século XIX, foram quatros batalhas em que os guaranis lutaram contra os invasores: Karitati (1840), Yuki (1874-1875), Murukuyati (1877) e, finalmente, Kuruyuki (1892). Assim, com a República, a população guarani reduziu consideravelmente (MORÓN, 2008).

Kuruyuki é um importante acontecimento na história guarani. Os fazendeiros, aliados aos militares, massacraram mil indígenas e seu líder messiânico Apiaguaiqui Tumpa.

Las consecuencias de la perdida de la última batalla, generó la servidumbre y esclavitud, donde, los hijos de los santiguos Iya (dueños) de ese gran territorio pasaron a ser Tembiokuai o Tembiau (siervos o esclavos) de los que se adueñaron de sus tierras, entre los cuales se repartieron a los hombres, mujeres entre niños, jóvenes y ancianos que tomaron prisioneros en las comunidades. Por lo que se produjo la desarticulación del espacio ocupado tradicionalmente por los guaranís, es decir, los grandes Téta Guasu desaparecieron y empezó un largo siglo de sometimiento (MINISTERIO DE LA PRESIDENCIA DE BOLIVIA, 2010, p. 22).

Em consequência do aniquilamento em Kuruyuki, os guaranis foram invisibilizados na esfera política nacional. Na antropologia, o conceito etnogênese (BARRETTO FILHO, 1999) é uma categoria analítica que pretende dar conta do processo de aparecimento de novas identidades étnicas e também do ressurgimento de etnias já reconhecidas. No entanto, acredito que tal conceito é limitador para compreensão do caso guarani que trago. Sobretudo depois de Kuruyuki esse povo foi invisibilizado no cenário político nacional por muitos anos, conforme já mencionei. Inclusive, vários estudos da época apontavam para o fim do povo.

Todavia, os guaranis, mesmo com os obstáculos em relação à sua reprodução cultural e ao seu "adormecimento" político, continuaram conscientes do seu pertencimento étnico. Assim como recordam das lutas coloniais contra os espanhóis, que, inclusive, demarcam suas diferenças em relação à sociedade nacional. Nesse sentido, a ideia de reelaboração político- 
cultural é mais pertinente para entender o "despertar" guarani a partir do fim da década de 1980, quando identificamos um contexto político nacional e internacional de afirmação e reconhecimento dos povos indígenas nas Américas. Sobre as razões da primeira comemoração, Pifarré (1992) nos diz que os guaranis "se mostraron como un pueblo que de nuevo levanta cabeza y que quiere um rol protagónico en la vida económica y política de Bolivia" (grifos meus) (p. 5).

Ainda, deve-se considerar que nessas décadas, na Bolívia, as identidades indígenas perderam a centralidade em relação aos movimentos operários e sindicais. Sendo muitos que atualmente se afirmam indígenas, antes se identificam a partir de critérios econômicos: camponeses ou operários. Como veremos na contextualização da APG, mais adiante neste capítulo, ela mesma começa a ser gestionada a partir de uma ideologia de classes sociais.

Em 1980, quase cem anos depois da vitória karai, os povos das terras baixas, de modo geral, começaram a regressar às suas terras, reconstruindo suas bases produtivas e suas organizações políticas. Com o respaldo de ONGs, de instituições da Igreja Católica e de lideranças regionais em favor da questão indígena, constitui-se, sob liderança guarani, a Confederación de Pueblos Indígenas del Oriente Boliviano (CIDOB), um representante nacional legítimo do movimento indígena das terras baixas bolivianas (LINERA, 2010). Sete anos mais tarde, surge a APG.

\subsection{O massacre de Kuruyuki em 1892}

A fundação da República da Bolívia, em 1825, foi acompanhada por várias mudanças sociais, porém quase nenhuma delas melhorava a vida dos indígenas das terras baixas. Pelo contrário, piorava as condições dos indígenas. Por exemplo, um dos primeiros decretos dos libertadores concedia terras aos que haviam combatido com o Estado. Historicamente, essas terras eram dos indígenas e de camponeses da região. Contudo, as leis do Estado boliviano passaram as terras para propriedade daqueles que combateram os indígenas, os grandes latifundiários.

Diante dessa conjuntura, era perceptível a condição miserável da maioria da população indígena na Bolívia. Muitos não tinham onde morar e cultivar. Alguns guaranis que formavam parte das missões franciscanas conquistaram a posse do território em nome da 
Igreja. Era uma propriedade coletiva, de toda a missão. Todavia, a maioria que não estava arregimentada em missões, que estava livre, foi cruelmente expulsa de suas terras tradicionais.

A partir de meados de 1840 a situação de penúria dos guaranis se agravou. Eles, que possuem uma cultura alimentar baseada fundamentalmente no milho, foram privados do cultivo nas terras que foram oficializadas em nome dos fazendeiros. A pecuária de bovino era a preocupação da elite local da época, sendo os guaranis explorados nessa atividade econômica.

Entre 1877, Pedro Zárate de Monteagudo, fazendeiro e responsável do governo pela distribuição de terras ocupadas por indígenas, mandou um servidor mais quatro soldados à localidade de Murukuyati para fazer trabalho de agrimensura. Estes foram desarmados e expulsos das terras pelas lideranças indígenas. Zárate, em reação, mandou tropas militares desde Monteagudo para destruir o povoado. Este senhor era bastante influente na região, além de fazendeiro e de exercer cargos públicos, chegou a ser deputado. O episódio causou comoção na região, mas como se tratava de indígenas, não se deu importância. Os massacres eram vinculados pelo colonizador como conduta necessária para lidar com indígenas rebeldes.

No massacre de Murukuyati, no qual, aproximadamente, 60 indígenas foram mortos, uma mulher foi degolada por soldados na frente do seu filho de sete anos. A criança, a partir de então órfã, foi resgatada entre os mortos e, depois, entregue para ser criado por um bruxo ${ }^{14}$ da região.

Apiaguaiqui, o menino que viu sua mãe ser barbaramente morta, ao ser educado por um bruxo, se fez sábio guarani, ipaye, isto é, aprendeu os segredos da cura por meio das ervas e, sobretudo, as formas de transmissão oral da cultura guarani. Da liderança comunitária, Apiaguaiqui se transformou em um dos maiores líderes messiânicos da região. Sua maior obsessão era libertar seu povo guarani. E acredita que poderia fazer isso por meio da violência física, respondendo às ofensivas coloniais da época.

Apiaguaiqui é retratado entre os guaranis como um homem profundamente conhecedor do seu povo e dos segredos da natureza. Como sábio e milagreiro, falavam que podia mudar o destino das pessoas. Inclusive, diziam que era ventríloquo, isto é, falava sem abrir a boca, de modo que a voz parecesse sair de outro lugar. Morando nas proximidades da

\footnotetext{
${ }^{14}$ Entre os guaranis na Bolívia, a figura do bruxo é comumente difundida como aquele responsável por curas e detentor de conhecimentos mágicos.
} 
comunidade de Ivo, Apiaguaiqui recebia, em sua casa, peregrinação de pessoas que demandavam curas ou apenas o queriam conhecer.

$\mathrm{Na}$ época em que patrões eram donos das terras e também dos indígenas que a habitavam, o grande guerreiro chegou a conformar um grupo armado, por meio do apoio dos caciques da região. Contra os karai, o "exército guarani" lutava contra escravidão, em favor da sua liberdade e da sua terra. Dizem que o objetivo era formar um grupo militar indígena que lutasse pelos guaranis dos três departamentos. Apiaguaiqui estava tão convencido do seu projeto bélico que dizia:

No teman ustedes a las balas porque por el poder que yo tengo cuando entre la bala se va a hacer liquido, no les va a hacer nada. Se va a salir la bala de por sí. El viento les va dispersar a las balas, no tengan miedo, yo los protejo (SANABRIA, 1972, p. 39).

Em uma das primeiras noites de janeiro de 1892, o corregedor de Cuevo estuprou e matou uma jovem indígena guarani. A fúria dos guaranis foi intensificada ao saber que o assassino não recebeu castigo nenhum, sendo este o estopim do massacre de Kuruyuki. Iniciou-se no dia 17 de janeiro a partir do ataque de um guerreiro guarani à tropa do tenente Sanz. Foram espalhados grupos de guerreiros guaranis por várias frentes de combate em grande parte da Cordillera. Apiaguaiqui era o grande guerreiro líder do enfrentamento. Na madrugada do dia 21, ele e mais cerca de mil guerreiros atacaram o quartel de Santa Rosa, sendo que os defensores do quartel se reforçaram com armas e munições para enfrentaram o exército guarani no dia 28. A derrota guarani traduziu-se em mil indígenas massacrados. Apiaguaiqui escapou entre os poucos sobreviventes. Esteve fugido por muitos dias, até que foi massacrado na praça principal de Monteagudo na tarde do dia 29 de março de 1892, pelos militares (SANABRIA, 1972).

Os guaranis lutaram contra os colonizadores e, da mesma forma, contra a sociedade nacional boliviana. Eles sofreram um ataque ${ }^{15}$, e no outro dia o exército boliviano tomou posse contra os montes em Kuruyuki, onde a batalha foi sangrenta, sendo derrotados os indígenas. Os combates começaram cerca de seis horas da manhã e duraram até às duas da tarde. Ao fim, as tropas do governo contavam nove mortos e trinta feridos, e do outro lado,

\footnotetext{
${ }^{15}$ Este ataque faz parte de uma série de enfrentamentos, tanto do exército como dos guaranis, que fora desencadeado porque o corregedor da região violou e assassinou uma jovem guarani parente de uma das lideranças da época (SANABRIA, 1972).
} 
aproximadamente mil indígenas morreram (SANABRIA, 1972). Vale ressaltar que Kuruyuki foi a última e mais violenta das batalhas do Estado contra esse povo. Anteriormente, nas mesmas circunstâncias coloniais, várias foram as pessoas mortas em decorrência da dominação do governo do Estado da Bolívia.

Primeiramente, os guaranis na Bolívia tiveram várias relações conflituosas com a Colônia e, logo depois, com o Estado. Eles lutaram por sua independência, resistindo obstinadamente até o massacre de Kuruyuki, quando morreram milhares de indígenas. A partir daí, foram institucionalmente desestruturados e expulsos de seus territórios, migrando para outras regiões da Bolívia e de outros países. O Estado boliviano, no contexto dessa batalha, sempre oprimiu qualquer forma de pretensão de soberania dos povos indígenas.

O massacre de Kuruyuki, como processo de opressão dos guaranis, teve como consequência o exílio desses indígenas para territórios remotos, além da inserção destes em um sistema de trabalho forçado em propriedades fundiárias da região. Com isso, os guaranis permaneceram ocultos no cenário político boliviano, chegando, inclusive, ao ponto de alguns historiadores considerarem o fim dessa etnia. O desaparecimento dos guaranis (ou chiriguano - como é referenciado na bibliografia historiográfica), isto é, seu etnocídio, é um consenso entre os historiadores que publicaram até o início do século XX. A maioria dos registros apresenta quatro opções explicativas para o suposto desaparecimento étnico do grupo: ou se escravizaram, ou morreram, ou migraram, ou mestiçaram (COMBÈS, 2005a).

Com a derrota em Kuruyuki, os guaranis se concentraram na recuperação de seu território e a na preservação de sua organização social como principal vínculo de representação de sua identidade étnica. A partir de suas aspirações e demandas territoriais, tema central em suas reivindicações históricas, eles identificaram claramente a entidade que lhes permitiria essa empreitada: o Estado. Assim, este se converte em um mecanismo de reconhecimento de sua existência étnica, já que havia sido ele mesmo quem os marginalizou e os excluiu inicialmente de seus direitos e da possibilidade de cidadania. Então, era também o Estado o único com o poder de devolver aos guaranis bolivianos tudo aquilo que ele lhes havia privado.

\subsection{A constituição da Asamblea del Pueblo Guaraní}

A economia da região do Chaco, ao redor da cidade de Camiri, se move, sobretudo, em torno da exportação de hidrocarbonetos e madeira, a pecuária e a agricultura, além da 
prestação de serviços. Destas atividades, apenas a agricultura e a pecuária de animais de pequeno porte são importantes para os guaranis. A economia petrolífera, a partir do monopólio da YPFB, beneficia pouco as comunidades indígenas. Além disso, frequentemente, comunidades indígenas e os ambientalistas denunciam exploração ilegal e contaminação por parte da empresa nas proximidades ou em comunidades indígenas.

A partir da segunda metade do século XX, os governos departamentais e nacionais, associados a grandes e médios fazendeiros, investiram no desenvolvimento da pecuária na região de Santa Cruz. Nesse contexto, houve um crescimento da produção de carne e leite por meio da aplicação em melhoramento genético de bovinos de corte, em insumos e em infraestrutura para pecuária e agricultura. Por outro lado, a falta de investimentos nas comunidades indígenas obrigou vários guaranis a trabalharem em condições de escravidão e servidão para fazendeiros e grandes latifundiários do Chaco.

A criação de gado se configurou como a principal atividade econômica da região da Cordillera. Além do poder econômico, os pecuaristas também passaram a ter grandes benefícios políticos. Na região, conforme observa Piffarré (1987, p. 34), “tener vacas es la principal carta de ciudadanía porque con ellas se adquiere más tierras y poder”.

Antes da década de 1980, na República boliviana, as comunidades guaranis, extremamente pobres, marginalizadas social e economicamente, ainda não se conformava como sujeito coletivo, sobretudo em termos nacionais. A mobilização indígena era inexistente ou pouco expressiva. A representação indígena na sociedade nacional era muito débil na região. Era a época das primeiras tentativas de configuração de uma organização unitária que representasse as comunidades guaranis e os demais povos indígenas das terras baixas. Vale lembrar que, nesse contexto, as demandas por cidadania se manifestavam por meio de sujeitos coletivos sindical, obreiro e camponês.

No fim de 1982, a Unidad Democrática y Popular (UDP) assumiu o governo, e o Movimiento de Izquierda Revolucionaria (MIR), partido político componente da UDD, tomou a responsabilidade de dirigir a CORDECRUZ, instituição da sociedade civil encarregada do desenvolvimento regional. Por sua vez, a Fundo Ganadero era uma instituição financeira de desenvolvimento da pecuária, credora da CORDECRUZ. Esta conjuntura culminou em novas perspectivas para os setores populares.

No ano seguinte, a CORDECRUZ começou a implantar na Cordillera um conjunto de ações, de curto a longo prazo, com objetivo de melhorar a condição econômica e social da 
população, em especial do pequeno agricultor campesino. No âmbito do planejamento estratégico de ações em desenvolvimento rural, por demanda da CORDECRUZ, o Centro de Investigación y Promoción del Campesinado (CIPCA), entre junho de 1985 e julho de 1986, realizou um estudo que resultou em um diagnóstico socioeconômico e um programa de desenvolvimento rural integrado para as comunidades guaranis - Programa de Area Cordillera. Desde 1976 a instituição já atuava entre os guaranis com atividades de promoção ao campesinato.

Posteriormente, de agosto de 1986 a janeiro de 1987, o CIPCA passou a divulgar os resultados e o programa nas comunidades da Cordillera, discutindo-o e construindo demandas. Além da divulgação do diagnóstico, realizaram oficinas sobre a história guarani. Essa ação do CIPCA se insere em um contexto em que várias ONGs, além da Igreja Católica, começaram a atuar de modo efetivo entre as comunidades guaranis. As atividades dessas organizações se concentravam em contornar situações de falta de terra, falta de infraestrutura, problemas de saúde etc.

A incompatibilidade manifesta das comunidades guaranis com o modelo organizativo proposto pela Central Sindical Unica de Trabajadores Campesinos de Cordillera (CSUTCC) foi experimentada durante quatro anos. Talvez porque os ideais do sindicalismo campesino não coincidam com as aspirações das comunidades guaranis. Ao mesmo tempo, instituições como a Igreja Católica, por meio de oficinas, cursos e encontros (história guarani, trabalho escravo, educação, produção agropecuária), impulsionaram um processo de reflexão que influi em uma tomada de consciência étnica por parte dos guaranis.

Essa tomada de consciência, que coincide com a morte dos principais capitães guaranis, possibilitou o surgimento de novos líderes guaranis, como, por exemplo: Silvio Aramayo, Guido Chumiray, Florentino Ramos, Hilarión Segundo e outros.

Outro aspecto importante dentro do processo de surgimento da APG é a presença das unidades coletivas de produção agropecuária que surgiram entre as comunidades guaranis como apoio do CIPCA. Essas unidades de produção, denominadas de Comunidades de Trabajo, foram verdadeiras escolas de formação e capacitação de uma nova geração de lideranças guaranis, que, posteriormente, desempenharam importante papel na construção da APG. Estas unidades de produção foram as primeiras referências organizativas das comunidades guaranis, servindo de base para a APG. 
No fim da década de 1980, alguns fatos da conjuntura regional, nacional e internacional confluíram para o lançamento da APG. Podemos citar: 1) o acirramento das desigualdades sociais em decorrência do crescimento da produção petroleira, com o consequente enriquecimento de grupos brancos e a exclusão das comunidades guaranis; 2) a experiência organizativa (rápida e pouco eficaz), mesmo que não fora bem-sucedida, adquirida na CSUTC; 3) a formação de lideranças guaranis; 4) o sentido mobilizador das unidades de produção agropecuária em algumas comunidades; 5) o trabalho de promoção realizado por instituições da Igreja Católica; 6) a problemática e as demandas sistematizadas no diagnóstico realizado pela CIPCA; 7) o processo de recuperação da consciência étnica presente nas atividades anteriores; além de 8) uma conjuntura internacional favorável ao reconhecimento dos povos indígenas, OIT.

\subsection{O movimento guarani na atualidade}

Com o avanço do liberalismo e a profunda crise do Estado da Bolívia durante as décadas de 1980 e 1990, os movimentos sociais bolivianos sofreram importantes mudanças políticas e culturais que afetaram suas organizações e, inclusive, transformaram suas identidades políticas e sociais. Nesse contexto, percebemos um ressurgimento das identidades indígenas a partir da perda da centralidade do movimento operário, particularmente os trabalhadores mineiros, que haviam sido o ator hegemônico junto com as organizações campesinas indígenas. O processo de recuperação cultural e identitária do povo guarani, assim como o surgimento da APG como instrumento organizativo deste povo indígena das terras baixas do oriente boliviano, se insere nesse contexto político, marcado por processos organizativos e pela reconfiguração identitária dos povos indígenas da Bolívia nas últimas décadas do século XX, assim como as diferentes ações coletivas de protesto em torno de demandas territoriais e de recursos naturais.

Para legitimar suas reivindicações, a APG constrói a ideia de uma nação guarani coesa em proveito de suposta "comunidade imaginada" (ANDERSON, 2008). Contudo, pode-se perceber, a partir da bibliografia etno-histórica dos povos falantes do idioma guarani, que nunca houve uma coesão guarani, devido às suas distintas formas de organização social e política. Para Combès (2005a, 2005b), uma das principais referências para esta proposta, o discurso contemporâneo da APG sobre o massacre de Kuruyuki é uma manipulação histórica por parte desse movimento indígena, isto é, uma estratégia etnopolítica de demonstração de 
unidade para legitimar suas reivindicações diante do Estado boliviano e das agências internacionais de defesa dos direitos indígenas.

A APG surge no ano de 1987, integrando mais de 80 mil guaranis em seu projeto. É uma organização com propostas de consolidação de uma nação guarani, que aglutina distintas comunidades guarani do sudeste boliviano, abrangendo os departamentos de Chuquisaca, Tarija e Santa $\mathrm{Cruz}^{16}$. As mais de 300 comunidades representadas localizam-se majoritariamente nas zonas rurais, constituindo o núcleo de base desse movimento social.

A APG é a instância máxima de gestão guarani na Bolívia. Ela é composta por um presidente e suas diretorias, denominada de PISET $^{17}$, que tem responsabilidades específicas. Por sua vez, a organização política guarani é constituída pelas capitanias ou zonas, que definem seus mburuvichas. Esta organização guarani, que concilia modos guarani e karai de fazer política, foi estabelecida, de certa maneira, por influência do documento Diagnóstico de la Cordillera (1985-86), que aponta a difícil situação que atravessa as comunidades guaranis na década de 1980. Na época, foi diagnosticado problemas no âmbito da produção, infraestrutura, saúde, educação e território, contudo, constantemente, a organização foi estabelecendo outras demandas, como, por exemplo, a de gênero, meio ambiente e comunicação. Com a finalidade de sustentar legalmente a organização, logo foram elaborados distintos estatutos orgânicos, nos quais se definem: os papéis das autoridades eleitas (mburuvichas), as regras das eleições e outras sanções, em função de procedimentos próprios. No contexto de plurinacionalização da Bolívia ${ }^{18}$, esses estatutos estão sendo reformados objetivando a conquista de prefeituras indígenas guaranis, isto é, as Autonomias Indígenas Originários Campesinas - tipo de autonomia prevista no Artigo 289 da Constitución Política del Estado.

A organização política tradicional dos guaranis se baseia no sistema de assembleias comunais, que representa cada uma das capitanias ${ }^{19}$. Por sua vez, cada capitania é

\footnotetext{
${ }^{16}$ Uma das discussões atuais da APG com o Estado é sobre as dificuldades de instauração de autonomias indígenas em nível departamental, já que os guaranis e a APG estão presentes em três departamentos distintos: Chuquisaca, Tarija e Santa Cruz.

${ }^{17}$ PISET é uma abreviação que se refere às responsabilidades iniciais da APG: Produção, Infraestrutura, Saúde, Educação e Território.

${ }^{18}$ No dia 7 de fevereiro de 2009, Evo Morales coloca em vigor a Constitución del Estado Plurinacional de Bolivia, texto elaborado pela Assembleia Constituinte e aprovada por referendum popular no dia 25 de janeiro do mesmo ano.

${ }^{19}$ A organização sociopolítica dos guaranis na Bolívia se baseia no tradicional sistema de capitanías. É um sistema de representação no qual o Mburuvicha Guasu atua como interventor interno entre os indígenas das comunidades, as autoridades públicas, privadas, além de mediar as demandas comunitárias com a APG nacional.
} 
representada por um número variado de comunidades. O Capitão Grande - Mburuvicha Guasu - é o ator político responsável por cada capitania, que atua de acordo com os costumes dos guaranis, além da incorporação de algumas lógicas organizativas sindicais. A APG mantém aliança com outras organizações indígenas e indigenistas da sociedade civil boliviana, dentre elas, a Confederación de Pueblos Indígenas del Oriente Boliviano (CIDOB), uma organização nacional que reúne vários povos indígenas da Bolívia oriental, isto é, dos departamentos de Santa Cruz, Pando, Beni e Chuquisaca. A CIDOB é uma das organizações indígenas mais representativas da Bolívia, possui considerável protagonismo nas ações coletivas de reinvindicações, de protestos e de marchas no cenário político atual daquele país.

A trajetória de luta da APG oportunizou que esta consolidasse seu processo organizativo e fosse crescendo nas regiões do departamento de Tarija e Santa Cruz. Assim, desde o primeiro número de Itika Guasu, a APG aumentou sua influência sobre a região chaqueña, estabelecendo novas capitanias em Villa Montes, Yacuíba e Karaparí. Nos últimos anos, o processo de organização dos guaranis de Tarija, por exemplo, está expandindo até a província de Bermejo na fronteira com a Argentina, na região de Yungas, onde ainda não estabeleceram capitanias regionais ${ }^{20}$.

Nas últimas eleições nacionais bolivianas, a APG, juntamente com outros movimentos indígenas e campesinos, foram os que oportunizaram, em certa medida, a vitória do partido político Movimiento al Socialismo (MAS). Essa estrutura política canalizou as demandas políticas de vários movimentos sociais na Bolívia contemporânea. A partir da conquista do líder cocalero Evo Morales ao governo nacional e da instauração de uma nova Assembleia Constituinte em 2005, encerrou-se o chamando "Ciclo de Protesto" (TARROW, 2009), iniciado cinco anos antes no contexto da Guerra del Agua de Cochabamba e perpetuado pela denominada Guerra del Gas, de 2003 (SVAMPA et al., 2010). Contudo, a partir de 2010, emergiram novos conflitos, protagonizados por diferentes movimentos sociais, nos quais a APG assume papel importante. A saber, demandas por territórios e recursos naturais justificadas a partir da diferenciação cultural possibilitam a abertura de um novo ciclo de debate político - e protestos - em uma complexa relação com o novo Estado Plurinacional da Bolívia.

Entre os guaranis as decisões são tomadas em Asambleas, instituição muito importante na sua organização política.

${ }^{20}$ Uma pesquisa futura no âmbito dos estudos comparados sobre a relação povos indígenas $\mathrm{x}$ estados (pluri)nacionais nas Américas, em continuidade a esta, seria comparar o movimento guarani boliviano com o argentino. 
Nos últimos anos, a APG, por exemplo, protagonizou importante conflito na região de Campo Margarita (Tarija), onde a empresa multinacional de hidrocarbonetos REPSOL YPF administra uma das maiores reservas do país. Esse conflito ocorreu devido às diferentes posições em relação aos usos dos recursos naturais em territórios habitados tradicionalmente por comunidades guarani. Ainda, no fim da década de 2000, essas disputas territoriais e de recursos naturais foram ampliadas para outras regiões do sudeste boliviano, isto é, a província do Gran Chaco (Tarija), composta por Yacuiba, Karaparí e Villa Montes, municípios em que a APG tem organizações de base.

Nesse sentido, podemos entender as ações coletivas da APG a partir do conceito de espacialidade da ação coletiva (BRINGEL, 2011), isto é, o espaço de atuação desse movimento indígena não é apenas um contexto da ação coletiva, mas, sim, um campo de disputa e de luta no qual a mudança dos lugares e a construção de novas territorialidades podem alterar as relações de poder. A trajetória de luta da APG oportunizou que esta consolidasse seu processo organizativo e fosse crescendo nas regiões do departamento de Tarija e Santa Cruz. Conforme disse anteriormente, a APG aumentou seu espaço de atuação sobre a região chaqueña, estabelecendo novas capitanias até as fronteiras com a Argentina. 


\section{Capítulo II: As teorias}

\subsection{Comemorações e festas nas Ciências Sociais}

Émile Durkheim é um dos principais autores clássicos das Ciências Sociais que discutiu as festas enquanto fenômenos sociais. Apesar de não ter constituído uma teoria sobre a festa, em As formas elementares da vida religiosa (2003) ele apresenta comentários aproximando o conceito de festa com o de ritual religioso. Em seus escritos as festas são compreendidas como momentos de efervescência e exaltação coletiva. Para esse teórico, as festas se aproximam das cerimônias religiosas, nas quais as pessoas são deslocadas para fora de si e do seu cotidiano. Ele propõe que as fronteiras que dividem os ritos que representam o deleite coletivo são instáveis, e também afirma que uma condição relevante da religião é seu elemento estético e recreativo (DURKHEIM, 2003). A discussão do conceito de festa de Durkheim é importante, pois nos permite compreender muitos aspectos de uma comemoração, isto é, um tipo especial de festa.

Para Durkheim (2003), todas as festas, mesmo aquelas predominantemente profanas em suas origens, apresentam características de cerimônia religiosa, porque em todas as situações elas têm por consequência estreitar o vínculo entre as pessoas, movimentar as coletividades, provocando um estado de exaltação e efervescência - características similares ao estado religioso. É sabido que existe uma diferenciação nos objetivos das duas atividades, uma cerimônia ritual tem uma finalidade séria, enquanto que a festa tem o intuito de divertimento. Porém, "no fundo a diferença está mais na proporção desigual segundo a qual esses dois elementos estão combinados" (DURKHEIM, 2003, p. 123).

As comemorações do massacre de Kuruyuki assumem, como veremos, o caráter de festa cívica entre os guaranis na Bolívia, há de se considerar que quando se pensa em comemorações, se pensa em festas. Essas festas permitem a constituição de novas interpretações do passado colonial, além de possibilitar um sentimento de pertencimento guarani, criando uma unidade coesa. Nesse sentido, essa festa tem como consequência a aproximação de pessoas, colocá-las em movimento, suscitando um estado de efervescência.

Segundo Durkheim (2003), a noção de individualidade é ofuscada durante as cerimônias religiosas, prevalecendo a vontade coletiva, isto é, na religião o indivíduo é controlado pelo coletivo. O mesmo acontece com as pessoas durante os momentos festivos, de efervescência. Nesses momentos, apesar ou por causa das violações das normas, as mesmas 
são reiteradas. Essas regras sociais ou acordos coletivos que garantem a vida em sociedade. Nesse sentido, é a partir da festa que o grupo revigora frequentemente o sentimento que tem de si mesmo e de sua unidade social. Simultaneamente, os indivíduos são reafirmados na sua natureza de seres sociais (DURKHEIM, 2003).

Portanto, os rituais religiosos, assim como as cerimônias festivas, são imprescindíveis para a manutenção da coesão social, pois com o passar do tempo a consciência coletiva inclina a enfraquecer, cabendo à religião atuar na manutenção dos vínculos sociais. Por conseguinte, pode-se considerar que quanto mais cerimônias festivas têm uma sociedade, maiores são as condições de resistência da unidade social. As festas seriam uma força no sentido contrário ao da dissolução social.

Além da comemoração do massacre de Kuruyuki servir de estratégia etnopolítica, uma vez que reelabora cosmologicamente um fato histórico do contato colonial como instrumento para afirmação de uma organização indígena, a participação guarani no cerimonial festivo e na organização da comemoração são significativas e tende a potenciar relações de solidariedade e de coesão social em uma região considerada etnologicamente diversa ${ }^{21}$.

Ainda sobre Durkheim (2003), há que considerar que ele nunca deixou de ver na religião uma fonte de solidariedade e harmonia. A partir das similitudes entre ritual religioso e cerimônias festivas, pode-se considerar que as festas proporcionam solidariedade. De modo genérico, solidariedade conduz à noção de laços sociais, de cooperação e de altruísmo. Uma relação de cooperação implica obrigações e expectativas mútuas, regras de reciprocidade, confiança social e compromisso cívico.

Segundo Durkheim (2003), a festa atinge seu clímax no momento de maior efervescência entre as pessoas participantes. Essa efervescência coletiva altera as condições psicológicas das pessoas, as sensações passam a ser mais fortes. Para assegurar esta condição, contribuem imensamente os elementos da festa: ritos, música, bebidas, comidas, danças etc. A festa de comemoração de Kuruyuki é marcada por muitos barris de chicha de milho, além de apresentações étnicas; as pessoas se vestem com trajes de festas e o local da cerimônia é previamente decorado com artefatos relativos à identidade guarani.

\footnotetext{
${ }^{21}$ Combés (2005b), dentre outros autores, afirma que a construção da APG é uma estratégia de guaranização dos povos indígenas chané. Enquanto os guaranis pertencem à família linguística tupi-guarani, os chané integram a família linguística aruak.
} 
A comemoração de Kuruyuki, enquanto apropriação do evento histórico pelos atores da APG, também será vista nesta dissertação como mecanismo de fortalecimento dos laços comunitários e aliança política entre os guaranis. Trata-se de uma estratégia etnopolítica de reelaboração cultural e de formação de uma consciência nacional guarani a partir da instituição de uma política de comemorações.

A política de comemorações de eventos pretéritos possibilita solidariedade entre os atores que manipulam sua história para legitimar a existência de uma comunidade política. Nesse sentido, alguns positivistas de inspiração comteana sugeriram que se elaborasse uma lista de personagens e acontecimentos históricos que fossem objeto de comemoração em cada Estado. Segundo eles, as comemorações públicas, homenageando os grandes homens que cooperaram positivamente para a história, a instituição de rituais nacionalistas, a construção de monumentos públicos, bustos, estátuas, bandeiras, fazem parte da estratégia de consagração política e simbólica. Assim, este trabalho se propõe a compreender os símbolos de constituição de uma concepção de nação guarani festivamente comemorada. Nesse sentido, coube indagar, quais as estratégias para a construção de uma ideia de nação indígena? $\mathrm{Na}$ atualidade, além de uma agenda comemorativa ${ }^{22}$, os guaranis reivindicam o efetivo uso da língua indígena nos trâmites oficiais, o reconhecimento do seu território, a autonomia administrativa etc.

As políticas de comemorações são habitualmente praticadas pelo Estado. O Estado brasileiro, por exemplo, entre os anos de 1988 e 2000, promoveu uma série de atividades para comemoração dos "500 anos de descobrimento do Brasil". Ideologicamente, essas celebrações performatizavam a distintividade da identidade nacional brasileira em relação aos outros países das Américas, reafirmando uma coesão e uma solidariedade da comunidade nacional (SILVA, 2003). No entanto, o que está em questão nesta proposta de pesquisa é a construção de uma comemoração protagonizada por povos indígenas e não pelo Estado. Nessa perspectiva, segundo Peixoto (2011), no Baixo Tapajós (Floresta Amazônica brasileira) a memória da Cabanagem é comemorada atualmente como um ideal de resistência política para a população que se autoidentifica como indígena. $\mathrm{O}$ movimento indígena na região se apropria da história da Cabanagem, organizando eventos celebrativos. Assim, aconteceu, em 2011, na comunidade de Cuipiranga: na comemoração dos 175 anos da Cabanagem os atores envolvidos salientaram o exemplo de resistência dos cabanos com o objetivo de revitalizar a

\footnotetext{
${ }^{22}$ Além da comemoração de Kuruyuki, os guarani na Bolívia reúnem-se também todo 29 de março para celebrar a data da morte do grande líder Apiaguaiqui Tumpa, ver SANABRIA FERNÁNDEZ (1972).
} 
luta política da atual comunidade indígena. Recentemente, tenho me atentado para a comemoração do massacre do rio Cururupe entre os tupinambás de Olivença, na Bahia, inclusive, também com uma marcha em memória do líder Índio Caboclo Marcelino, massacrado.

As memórias do fato histórico apropriado descortinam no presente diferentes significados para os atores sociais que disputam a representação dos eventos pretéritos. Nesse sentido, o tempo não é apenas físico, marcado pelo calendário. O tempo é, sobretudo, social. O desenrolar deste evidencia mudanças nas relações sociais que se decidem politicamente celebrar.

Se Kuruyuki foi um massacre dos povos guarani praticado pelo exército do Estado da Bolívia, por que comemorar um massacre? Como se processam celebrações quando o evento motivador é um infortúnio? O evento traumático é reverenciado coletivamente pela "comunidade de memória" quando se processa a transição da experiência do sinistro para a experiência da libertação (TURNER, 1982), isto é, uma comunidade só decide datar e comemorar uma catástrofe quando ela passa a representar noções de superação e de sobrevivência às experiências do infortúnio.

Estudar a comemoração de Kuruyuki no âmbito das Ciências Sociais implica discutir o uso social do passado pelas sociedades contemporâneas. Nesta parte, duas concepções teóricas contribuem: a de lugares de memórias (NORA, 1993) e a de invenção de tradição (HOBSBAWM; RANGER, 1997). Nesse sentido, aqui as comemorações são entendidas como lugares de memória e invenção de tradições.

"Lugar de memória" é um dos conceitos mais cunhados do historiador francês Pierre Nora. Comumente esse termo é apropriado pelas ciências humanas para constituir uma definição de museu. Todavia, esse conceito não se restringe aos museus. Monumentos, instituições, rituais e comemorações também são lugares de memória. São construídos com o intuito de preservar uma memória oficial, em outras situações e sociedades a memória é algo vivido no dia a dia e a sua preservação, realizada pelos próprios grupos sociais (NORA, 1993). Nesse sentido, os lugares de memória são resultados da organização seletiva, voluntária e intencional, não se configuram como memórias espontâneas. Daí, a necessidade de procurar e acumular vestígios, testemunhos, documentos acerca do passado, que se tornarão provas e registros daquilo que já passou. 
O conceito foi apresentado por Nora na obra Les lieux de mémoire, uma coletânea de três volumes publicada entre 1984 e 1992. O contexto de formulação desse conceito é o século XX, sobretudo na França, período denominado de "era da comemoração", quando se assistiu a uma grande preocupação com o fenômeno comemorativo. De acordo com Nora (1993), é um século marcado por diversos comemoracionismos. Nessa época, os Estados representavam sua soberania por meio de hinos nacionais, de bandeiras e de comícios, o que Eric Hobsbawn diz serem típicos da Europa do século XIX.

Uma das concepções de memória que mais converge com este trabalho é a de Michael Pollak (1989), que se interessa pelos conflitos, pelos processos e atores que intervêm no trabalho de constituição e formalização das memórias. Isso implica que a produção de uma memória é um processo impositivo, um modo particular de dominação ou violência simbólica. A memória não é estabelecida naturalmente, mas artificialmente. Entretanto, considerando que a memória é constituída, também, pela interação entre diferentes atores dos grupos sociais, repousa sobre as trocas e delimita um patrimônio imaterial que contribui para identificação das pessoas em um determinado grupo social (HALBWACHS, 1994). Esta identificação permite situar a coletividade no passado, no presente e no futuro e concluir que a memória é uma dimensão política, social e simbólica.

A globalização teve significado essencial nas transformações sociais entre os povos indígenas nas Américas. Ela permitiu a divulgação dos valores democráticos, dos direitos humanos e do reconhecimento das diferenças. A Convenção $n^{o} 169$ da Organização Internacional do Trabalho (OIT), sobre Povos Indígenas e Tribais em Estados Independentes, que reconhece os direitos dos povos indígenas, é o documento mais importante e difundido. Nesse sentido, as noções de "identidade e memória" também foram apropriadas politicamente pelos indígenas. Assim, "identidade e memória" são dois conceitos que repercutem para além de seus contextos originais, a Europa.

A contribuição de Hobsbawn e Ranger (1997) sobre a discussão dos usos do passado é no sentido de ressaltar o caráter fictício das tradições. Eles apresentam uma perspectiva que tenta dar conta das tradições construídas e formalmente institucionalizadas, o modo como eles surgem e como se estabelecem. Hobsbawn $(1997$, p. 9) chama de "tradições inventadas":

um conjunto de práticas, normalmente reguladas por regras tácita ou abertamente aceitas [...], de natureza ritual ou simbólica, [que] visam inculcar certos valores e normas de comportamento através da repetição, o que implica, automaticamente, uma continuidade em relação ao passado. 
A globalização do capitalismo, e sua consequente aceleração da dinâmica das mudanças sociais, bem como a crise da manutenção das tradições, se estabelecem diante da necessidade de resguardar um passado do qual consideram apropriado lembrar-se. Assim, as tradições inventadas são reações a situações inéditas que ou assumem a forma de referências a situações anteriores, ou constituem seu próprio passado por meio da repetição quase obrigatória. É o contraste entre as sucessivas mudanças e inovações oriundas da cultura moderna e a da tentativa de estruturar de modo imutável e invariável ao menos alguns aspectos sociais. Logo, trata-se de um domínio da história contemporânea.

Ranger (1997), em seu texto A Invenção da Tradição na África Colonial, mostra como os colonos brancos, geralmente de origem operária ou campesina, entre 1870 e 1890, manifestavam nas colônias africanas suas tradições inventadas na Europa. Esses colonos, por serem brancos, eram representados a partir de um status semelhante ao do alto império inglês. Por outro lado, a pequena burguesia nativa ressignificou as novas tradições europeias para seus próprios interesses, constituíram reinos, cerimônias, coroações e outros. Assim, os africanos manipulavam as tradições: "os europeus acreditavam que os africanos pertenciam a tribos, os africanos criaram tribos as quais pudessem pertencer” (RANGER, p. 260).

Esta questão é importante, pois destaca as iniciativas, reconhecendo o papel dos colonizados diante do processo de invenção da tradição e de apropriação das estruturas ocidentais, mostrando que não se trata de movimento imposto unicamente de cima para baixo. Por último, a noção de invenção da tradição para Ranger e Hobsbawm é caracterizada como algo em curso, isto é, um processo social e político que surge de interações e contextos específicos.

\subsection{A consciência nacional entre indígenas nas Américas}

Além das instituições, território, língua e código jurídico próprio, as culturas nacionais são constituídas pelo compartilhamento de símbolos e representações. Uma cultura nacional é um discurso apresentado de modo a influenciar e organizar tanto nossas ações quanto a concepção que temos de nós mesmos. Nesse sentido, as culturas nacionais constroem identidades, ao produzir sentidos sobre "a nação" (HALL, 2003). Esses sentidos estão presentes na interpretação dos fatos históricos e nas imagens que conectam o presente ao passado. 
Conforme afirmou Anderson (2008), a identidade nacional é uma "comunidade imaginada". Para ele, as diferenças entre as nações existem devido às distintas formas pelas quais elas são imaginadas. Nesse sentido, essa ideia permite perceber como os guaranis se imaginam como nação, bem como eles interpretam e se interpretam na nação boliviana. Quais as contradições desse processo? O que o Estado e a APG fazem com essas contradições? Existe relação com o modo de constituição das nações modernas? Que estratégias são acionadas para construir um senso comum guarani sobre o pertencimento ou sobre a(s) identidade(s) nacional(is)? Até que ponto existe uma consciência nacional em formação entre os guaranis no âmbito do projeto plurinacional boliviano? Estas são algumas das questões que essa discussão teórica nos traz.

Segundo Bartolomé (2002), a condição de nação ou nacionalidades que muitos povos indígenas vêm proclamando em toda América entra em conflito com a imagem que tradicionalmente as Ciências Sociais têm do Estado: uninacional, homogêneo em termos políticos e culturais. Em alguns contextos, a autodenominação nesses termos por povos indígenas é vista com bastante temor por segmentos da sociedade e do Estado. O argumento é de que a constituição de diferentes nações dentro de um Estado fragmentaria a política, o que, por sua vez, ameaçaria a soberania nacional do Estado.

Nesse sentido, talvez, a resistência em aceitar o caráter nacional das comunidades étnicas dentro de um Estado é colaborada pela naturalização da relação entre Estado e nações. Por exemplo, no caso do Brasil, de acordo com Ramos (1993), os povos indígenas, como "nações dentro da nação, não têm qualquer perspectiva de se transformar em Estado, nem de promover um nacionalismo indígena". Mesmo assim, setores contrários às demarcações das terras indígenas brasileiras não são simpáticos à identificação dos indígenas a partir de nacionalidades. Eles alertam para o perigo da expressão de perigo em relação à soberania nacional. Como se nação apresentasse as mesmas demandas de Estado.

Nação é diferente de Estado. Para Bartolomé (2002), nação é um tipo de associação humana estabelecida a partir de fatores culturais, históricos, econômicos e políticos. Esta ideia tem uma estreita relação com o que as Ciências Sociais conceituam como etnia. A maioria das nações não pode ser reduzida exclusivamente a uma origem étnica, situação na qual se encontra a maioria dos que se assumem enquanto nacionalidades. Assumem-se como uninacionais, mas na verdade não o são. 
No âmbito das discussões sobre movimentos indígenas, um aspecto importante é a construção de uma identidade em comum no sentido de aglomerar o maior número possível de pessoas, para, assim, ter uma articulação mais favorável com o Estado. Nesse sentido, para Bartolomé (2002), este processo pode ser analisado a partir do conceito de (re)construção nacionalitária, isto é, uma identidade compartilhada que nem sempre corresponde a uma configuração étnica precisa.

Bartolomé (2002) usa o termo nacionalitário para diferenciar da outra construção social fundamentada a partir da ideologia do nacionalismo, enquanto relação com o sentimento patriótico. Além do mais, como já dito, nas Ciências Sociais, frequentemente, os conceitos de Estado e nação são tratados de uma forma quase indiferenciada. Isso se deve ao fato de que os Estados sempre procuravam criar suas comunidades políticas e culturais homogêneas, eliminando as diferenças, até o ponto que passaram a identificar Estado e nação como sendo a mesma entidade.

Assim, de acordo com Bartolomé (2002), processos de construção nacionalitária são entendidos como a busca por construir sujeitos coletivos que apelam por uma identidade social compartilhada, baseada em uma tradição cultural própria ou apropriada e que pretende se relacionar em termos igualitários com outros conjuntos culturais que formam parte do mesmo Estado. Nesses termos, constituir uma nação, enquanto sujeito político, não implica defender um aparelho estatal próprio.

Para Bartolomé (2002), o atual processo de (re)invenção dos indígenas a partir de categorias nacionais se deu a partir da apropriação das categorias do próprio Estado, enquanto projeto moderno ocidental colonial. Entretanto, esta apropriação possibilita, ao mesmo tempo, que os indígenas se diferenciem e, também, conquistem maior reconhecimento político, uma vez que passam a se expressar "nos mesmos termos" que a sociedade política dominante, sendo compreensíveis para estes.

A discussão desta dissertação se aproxima do debate conhecido comumente como “nacionalismo étnico". É importante considerar este debate, pois ele permite diferenciar esse tipo de nacionalismo em relação ao nacionalismo cívico. Smith (1986) defende que muitas nações têm origens étnicas anteriores à modernidade. Contudo, naquela época, não se concebiam como nação, uma vez que o nacionalismo é um processo fundamentalmente ocidental moderno. No entanto, o nacionalismo também é observado na África, Ásia e 
Oceania, ou seja, em contextos não ocidentais. Mesmo o nacionalismo latino-americano é problematizado como "ocidental” ou não.

Em termos conceitos de Smith (1986), nação é uma povoação humana denominada que ocupa um território histórico e compartilha mitos e lembranças, uma coletividade, uma cultura pública, uma só economia e direitos e obrigações comuns. Nesse sentido, nação é diferente de Estado, bem como é diferente de comunidade étnica. Não corresponde a um Estado porque este é um aparato institucional burocrático com autonomia. Não corresponde à comunidade étnica, pois esta não tem o alcance político que geralmente as nações têm.

De modo geral, normativamente, as nações se prepõem como um sistema de representação homogêneo, produtor de identidades unificadas, isto é, elege determinados elementos culturais, em detrimento a outros, para representar a coletividade pretendida. No entanto, no plano empírico, as nações nunca foram homogêneas, por isso penso ser mais adequado compreender a identidade nacional enquanto conjunto de processos diferenciados e diversos, inerente a classes e grupos sociais - pelos quais as pessoas se identificam com um coletivo cultural para além das suas relações imediatas de interação (WOLF, 2003). Nação deve ser analisada enquanto processo atrelado a um tempo e espaço específico. Assim, como qualquer identidade, em termos sociais, não se constitui estática, todavia experimenta novos rearranjos e transformações.

Wolf (2003) nos mostra que os membros de uma nação participam de maneiras diferentes "nas relações comuns históricas e funcionais da ecologia, estruturação social e aculturação", salientando que essas relações são socialmente moldadas e expressadas por meio de símbolos. Estes, por sua vez, só podem ser compreendidos em seus contextos, a partir de uma análise que leve em consideração o emaranhado de conjunturas concretas que rodeia o estabelecimento e a influência desses símbolos.

Ainda, é fundamental trazer a discussão sobre movimentos sociais de modo geral, em especial, seu diálogo com o movimento indígena. Estes nos possibilitam compreender os processos e as conjunturas que envolvem a prática política indígena nas Américas. O debate parte da ideia de que a conformação dos movimentos indígenas não se resume ao mero reflexo do poder do Estado diante dos povos indígenas. Assim como outros movimentos sociais da América latina, o movimento indígena constitui seus próprios significados e limites do seu sistema político. 
Atualmente, os movimentos sociais latino-americanos põem em ação uma política cultural com significados e práticas que podem ser a origem de processos que devem ser aceitos como políticos (ALVAREZ; DAGNINO; ESCOBAR, 2010). Nessa perspectiva:

A cultura é entendida como concepção de mundo, como conjunto de significados que integram práticas sociais, não podendo ser entendida adequadamente sem a consideração das relações de poder embutidas nessas práticas. [...] A compreensão da configuração dessas relações de poder não é possível sem o reconhecimento de seu caráter "cultural" ativo, na medida em que expressam, produzem e comunicam significados (idem, p. 17).

A expressão política cultural frequentemente se refere às lutas simbólicas em torno de conteúdos culturais em que o que está politicamente em questão, para os atores sociais, é complicado de discernir. As políticas culturais condicionam fundamentalmente quais grupos e pessoas têm poder para definir esses significados. Nesse sentido, as políticas de representação têm um vínculo direto com o exercício das relações de poder (ALVAREZ; DAGNINO; ESCOBAR, 2010, p. 17). Esta dissertação nos mostra que é no âmbito da APG que se definem os elementos que devem ser representados na nação guarani.

Para encerrar este capítulo, cabe destacar a consideração presente no texto (ALVAREZ; DAGNINO; ESCOBAR, 2010, p. 17) de que as culturas políticas na América Latina são fortemente influenciadas por aquelas que se constituíram e prevalecem na Europa e nos Estados Unidos, porém se diferenciam delas. Esta influência se expressa a partir de princípios como o racionalismo, universalismo e individualismo, no entanto, esses se combinam historicamente com concepções intrínsecas à América Latina. 


\section{Capítulo III: A comemoração de Kuruyuki}

\subsection{A primeira comemoração}

A primeira celebração de Kuruyuki, dia 28 de janeiro de 1992 - depois de uma grande marcha até as trincheiras -, contou com guaranis de distintas comunidades e capitanias. Esse evento, organizado pela APG e por instituições locais de desenvolvimento, além das ONGs e da Igreja Católica, teve vários discursos de autoridades políticas do Estado da Bolívia e de lideranças guaranis, sendo que muitos deles aludiam à solidariedade e unidade dos guaranis e investiam na educação como novo e principal instrumento de luta desse povo. Inclusive, foi lançado na ocasião um programa de EIB - Educación Intercultural Bilingüe. Dentre vários letreiros que apareceram na multidão, destacou-se o seguinte: Muertos de Kuruyuki, surjan de sus trincheras, marchen con nosotros hacia la Tierra sin Mal.

Desde 1992 os guaranis se reúnem em Kuruyuki para comemorar o massacre do fim do século XIX. A comemoração - além de ser uma grande festa na qual familiares e amigos se encontram para conversar, dançar, beber chicha de maíz - é um encontro político, momento para anunciação pública de demandas, de benfeitorias, de projetos etc. Em 1992, por exemplo, na homenagem ao centenário do massacre de Kuruyuki, como acabei de mencionar, foi implantada a campanha de alfabetização bilíngue promovida pela APG e pela Teko Guarani, sendo que essa cumpre até os dias atuais importante papel no programa de educação intercultural e bilíngue entre os guaranis.

Começaram a mobilização de 1992 com uma marcha até a comunidade de Ivo, com a finalidade de descobrir uma placa recordatória em nome dos guaranis mortos no massacre. Posteriormente, se concentraram nas proximidades das trincheiras em Kuruyuki, onde foram extraídos os restos ósseos dos guaranis mortos no massacre, sendo depositados em recipientes de cerâmicas para serem transportados até o Cemitério de Ivo, onde haviam preparado um ossuário, específico para aqueles ossos. Os ossos foram retirados das trincheiras e preparados antes da celebração de 1992, cabendo aos organizadores procurar e selecionar os ossos mais adequados à exposição na comemoração. Logo após uma missa celebrada pelo bispo Juan Pellegrini, transportaram os ossos para o ossuário no Cemitério de Ivo. Na ocasião, ele disse: "Al gobierno, a las autoridades, les toca encontrar la manera de reparar la injusticia del pasado y servir de veras a este pueblo tan importante en la vida nacional" (PIFARRÉ, 1992, p. 13). 
Não existe um consenso em relação ao número de pessoas presentes na primeira comemoração. Segundo periódicos nacionais que noticiaram a primeira celebração, aproximadamente seis a sete mil pessoas assistiram ao evento, caracterizando uma mobilização robusta por se tratar da primeira edição. Já Pifarré (1992) registra cinco mil participantes.

Em agosto, em conversa informal no Mercado Central de Camiri, Antonio Mendez me contou sobre a participação dele na grande marcha que antecedeu a primeira comemoração de Kuruyuki, em 1992. Ele, juntamente com centena de outros guaranis de diferentes comunidades - na época, Mendez era professor em Isoso - iniciaram caminhada com dez dias de antecedência do evento. Ademais da grande dimensão comunitária da marcha, ele foi um grande encontro entre comunidades que até então não se conheciam. Mendez me falou, por exemplo, que poucas vezes os guaranis de Isoso interagiam com os de Charagua.

A marcha foi organizada fundamentalmente com atuação da CIPCA, da Igreja Católica e das lideranças locais mobilizando as comunidades. O primeiro ponto de aglomeração de partida da marcha deu-se no cruzamento da linha férrea em Gutierrez com a Ruta 9, $79 \mathrm{~km}$ norte de Camiri, onde os guaranis se concentraram com outros para então seguir até Ivo e Kuruyuki. De acordo com Mendez, entre os participantes, além de homens adultos, havia muitas mulheres e crianças.

Por último, é importante destacar que a primeira comemoração de Kuruyuki oficializou abertamente a criação da APG como organização matriz dos guaranis na Bolívia.

\subsection{As últimas comemorações}

A programação da celebração do massacre de Kuruyuki, algumas vezes, é distribuída entre os dias 26, 27 e 28 de janeiro de cada ano. Quando incluem um ou dois dias que antecedem o 28, geralmente, esses dias são usados para o deslocamento das pessoas até Ivo ou para festejarem antes dos atos principais. É iniciada com a chegada de cada uma das delegações guaranis, provenientes de diferentes regiões, na comunidade de Ivo, no Chaco chuquisaqueño. Nas últimas festas, a presença do presidente Evo Morales, no ato central da programação, foi considerada um dos momentos com maior repercussão entre os guaranis e convidados. 
A partir de dados como panfletos e jornais da época, observei que a celebração realizada em 2012 foi realizada em memória aos 120 anos do massacre, por se tratar de um número "redondo", mais expressivo - tal celebração se configurou como uma das mais movimentadas, depois da primeira de 1992. Em 2012, a programação do evento foi iniciada com os campeonatos esportivos durante o primeiro dia, sendo que a noite desse dia foi movimentada por variadas atividades artísticas. No segundo dia, dentre outros compromissos, ocorreram: a apresentação da história dramatizada sobre Kuruyuki representada por crianças da comunidade de Laurel e Tenta Piau das Capitanias de Kereimba Renda e Huacareta, a exibição de vídeos produzidos pela Teko Guarani e, paralelamente ao conjunto de atividades propostas, decorria uma exposição de artesanatos, documentos e comidas típicas dos guaranis. O último dia foi reservado para a agenda formal, isto é, os discursos dos representantes da APG e do Estado Plurinacional da Bolívia, dentre eles, a fala do presidente Evo Morales para encerrar o ato (ASAMBLEA DEL PUEBLO GUARANI, 2012).

\subsection{A comemoração de 2013}

Participei de comemoração específica desse ano. Cheguei pela primeira vez em Camiri no fim da tarde do domingo, 27. Instalei-me em um hotel perto da praça da cidade, liguei e, posteriormente, me encontrei com Antonio Mendez, que me recebeu com bastante entusiasmo, talvez por ter sido apresentado por Isabelle Combès, antropóloga francesa que trabalhou com ele em Isoso. Tivemos uma primeira conversa por horas na praça, ao final, combinamos de ele passar no hotel em que eu estava, às 5 h30 da manhã do outro dia, 28, para irmos ao evento.

Nesse dia, nos encontramos no horário marcado, pegamos um dos táxis que circulam 24h por Camiri e fomos até a sede da APG, de onde às 6h sairia um micro-ônibus em função do evento. Na porta da APG Nacional (Figura 5), esperamos por cerca de uma hora o transporte, juntamente com dezenas de guaranis. Foi o momento em que Antonio começou a me apresentar algumas lideranças que também estavam ali. Dentre estes, fui apresentado ao então presidente da APG Faustino Flores (2009-2013). Ele estava muito atarefado com os preparativos do evento e, a priori, não pode me dar atenção, até o momento em que Antonio disse que eu era brasileiro. Na verdade, Antonio me apresentou detalhadamente, dizendo que eu era um pesquisador brasileiro e que gostaria de acompanhar Kuruyuki para estudo e, posteriormente, conversar com mais tranquilidade sobre meu projeto de pesquisa com 
lideranças da APG. Das palavras de Antonio sobre mim, Faustino se ateve apenas ao fato de eu ser brasileiro, pois também havia outras pessoas na roda a quem Faustino dispensava atenção. Tradicionalmente, convidam representantes guaranis do Paraguai, Argentina e Brasil para participarem de Kuruyuki. Como em outros anos, havia lideranças indígenas dos dois primeiros países, porém ninguém do Brasil. Sabendo minha nacionalidade, Faustino me chamou reservadamente, questionou se eu era guarani, eu neguei e ainda disse que nunca tinha conversado com nenhum guarani brasileiro. Mesmo assim, ele me convidou a fazer um pronunciamento "en nombre de los hermanos guaraníes de Brasil”. Recusei, explicando que não achava sensato, pois não os conhecia. Com isso, ele infelizmente encerrou a conversa e voltou para a conversa com outras lideranças. Não demorou e o micro-ônibus chegou para irmos a Ivo, contudo as principais lideranças partiram em uma caminhonete $4 \times 4$. Passei todo o caminhando conversando com Antonio sobre o mundo guarani, com isso percebi que ele tinha uma noção apurada do trabalho dos antropólogos entre eles. Ele me disse que já acompanhou muitos antropólogos em trabalho de campo por todo o território guarani.

Durante a ida até Ivo, Antonio também me explicou seu envolvimento com Kuruyuki, ele participou da organização da marcha em 1992. Contou que na primeira celebração muitos guaranis foram pela primeira vez em Camiri e na região de Ivo. Já outras pessoas ou famílias aproveitaram a viagem para rever parentes e amigos.

Saímos pelo sul de Camiri através da Ruta 9 (Figura 2 e 3). Depois de 1h na rodovia asfaltada, cruzando uma vegetação verdejante, mas com rios completamente secos. Percorrendo $58 \mathrm{~km}$, depois da ponte sobre o rio Cuevo, entramos à direita em uma estrada de chão. Logo atravessamos a comunidade de Kuruyuki, em seguida, chegamos a Ivo, município de Macharreti, departamento de Chuquisaca.

Assim que chegamos em Ivo, às 9h30, caminhamos pelas principais ruas e chegamos à parte central onde está o salão de festas, o palanque e o campo para o público. Depois de conhecer a escola indígena, o posto de saúde e a igreja, fomos à casa de Lorenzo, um amigo de Antonio. Lorenzo é capitão e agricultor na região. Na casa dele permanecemos por aproximadamente duas horas e retornamos para o almoço.

Durante o ritual de Kuruyuki os elementos do cotidiano da comunidade de Ivo se reconfiguram, recriando universos sociais e simbólicos. Os residentes do lugar são os anfitriões dos guaranis de outras localidades. Barracas são instaladas nas áreas públicas para pernoite de algumas pessoas. Ademais, a dimensão comunitária da alimentação é 
potencializada, uma vez que os anfitriões se responsabilizam pela comida servida. Na casa de Lorenzo, sua esposa Judith lidera o preparo do milho e das batatas entre outras mulheres, no interior da casinha de pau a pique desconexa da outra parte que servia como dormitório. Já na parte externa, um grupo de homens assava carne de gado doado pelo deputado guarani Efraín Balderas Chávez, que foi presidente do Consejo de Capitanes Guaraníes de Chuquisaca $(\mathrm{CCCH})$ de 2001 a 2006. Bem como outras lideranças guaranis que estavam na APG e agora são parlamentares. É o caso do também deputado Wilson Changaray Taborga, que antes era presidente da APG Nacional, de 2005 a 2009.

Conversando com Antonio durante o evento, ele frisou que atualmente Kuruyuki é bastante lembrado pela maioria dos guaranis, porém não era assim antes da marcha de 1992 . Anteriormente, apenas as próprias comunidades de Ivo e Kuruyuki, e arredores, tinham dimensão e memorizavam o massacre. Inclusive fazendo rituais religiosos ${ }^{23}$ na localidade conhecida como trincheiras. Trata-se de um massacre de aproximadamente mil indígenas, porém com pouca ou inexistente repercussão nacional na época.

No dia anterior, 27 de janeiro, a organização tinha colocado a bandeira guarani na praça principal da comunidade de Ivo, entrada da cidade. Quem chegava percebia que o lugar estava em festa. As mulheres da comunidade tinham preparado a decoração do salão de festa, palanque. Apesar do clima descontraído decorrente do encontro entre as pessoas, os mais velhos, de modo geral, se apresentavam mais contidos e reflexivos. Para alguns destes, aquela situação tinha uma dimensão religiosa, lembrando-se de parentes próximos que foram mortos no massacre. Já para outros, tratava-se de um encontro para renovar as forças em busca da liberdade guarani, Terra sem Mal, iva marei. Presente no evento, Nicolasa Callejas, gestora da Escuela Tekove Katu, considera que Kuruyuki é um grande encontro entre os guaranis, “(...) es el momento en que los líderes pueden reunirse para discutir temas de interés de la Nación guarani", me disse em conversa.

Debaixo do intenso sol chaqueño, chegavam caravanas de pessoas que logo se posicionavam adiante do palanque. Entre os que conversavam de pé, instalaram tendas de exposição das cooperativas. Já outras pessoas destacavam cartazes, faixas e bandeiras.

\footnotetext{
${ }^{23}$ Quando visitei a região com Felipe Román percebi que existiam restos de velas queimadas no terreno para ritos religiosos de familiares para entes mortos no massacre. A dimensão do luto, um dos consequentes aspectos do massacre, poderia ser abordada em outro estudo, isto é, os sentimentos dos guaranis da localidade de Kuruyuki em relação ao massacre. Essa sugestão de pesquisa demandaria um trabalho de campo extenso entre os anciões da região, o que eu não tive oportunidade no mestrado.
} 
Fileiras de soldados do exército se posicionaram próximo ao descampado do palanque. Foi esta a mesma entidade que em 1892 massacrou os guaranis naquela mesma região. Entretanto, agora os militares estavam em Ivo para prover a segurança dos chefes do Estado que estavam presentes. Discutirei este ponto mais à frente.

Caminhonetes $4 \mathrm{x} 4$ da $\mathrm{APG}^{24}$ estacionavam próximas às tendas para o descarrego de garrafões com chicha para sanar a sede de aproximadamente mil pessoas que aguardavam para ouvir as lideranças guaranis e alguns convidados representantes do governo nacional.

Até o momento do almoço nenhum dos itens da programação impressa e assinada pelo presidente da APG tinha sido realizado. As pessoas criavam conjecturas, porém não se sabia das razões do atrasado dos discursos políticos no palanque, que até então não tinha nenhuma autoridade. Depois de quase uma hora, fomos informados de que os atos cívicos foram protelados para o dia seguinte, 28, em função da agenda do presidente Evo Morales, que aproveitaria Kuruyuki para inaugurar algumas instalações da Unibol que ainda estavam em construção.

O presidente Evo Morales fora convidado pela APG para estar em Ivo no dia 27 de janeiro para a comemoração de Kuruyuki. O público que estava na expectativa de ver o presidente naquele dia foi surpreendido por esse adiamento da visita para o dia seguinte, na segunda-feira. Naquele dia, Evo Morales foi para o encontro Cumbre de los Pueblos, reunião de representantes de movimentos sociais socialistas da América Latina e do Caribe, realizado em Santiago no Chile. Em Kuruyuki, a programação referente ao presidente foi remanejada para o dia seguinte. Dentre elas, a inauguração da Unibol e os discursos das lideranças. Em consequência, percebi a dispersão do público que acompanhava a comemoração. Algumas pessoas com quem conversei estavam descontes com o remanejamento da programação, argumentavam que a festa é realizada em função do povo guarani, e não do presidente. Elas defendiam que todas as atividades seguissem normalmente no dia 27 , sem o presidente.

A partir desse imprevisto foi possível perceber algumas das dissidências entre o movimento da nação guarani. Isso foi importante para perceber que a APG apresenta uma estrutura atomizada, de certo modo, e orientada por disputas e conflitos de interesses entre os subgrupos internos, como, por exemplo, as APG zonais ou polarizações entre capitães nas comunidades. Com isso, notei que existe uma representação idealizada da "comunidade", de acordo com o movimento guarani. Esta discussão é oportuna, pois nos faz problematizar um

\footnotetext{
${ }^{24}$ Os carros foram viabilizados a partir de projetos de cooperação internacional com ONGs.
} 
dos principais dogmas em relação ao conceito de comunidade: sua pretensa coesão e unidade. Questionar essa perspectiva idealizada pode contribuir na elaboração de políticas públicas voltadas para esses grupos.

Uma das debilidades da atual APG Nacional, que promove Kuruyuki, é o fraco diálogo com as comunidades. A visão política das organizações indígenas nacionais ou regionais não é conhecida pela base. Diante disso, a circunstância com Morales constituiu grupos favoráveis e contrários à conduta da APG que, a partir deste fato, questionavam outras ações e programas da organização. Aqueles que estavam em descordo aproveitam o ensejo para se queixarem da cumplicidade do presidente da APG com o presidente da República.

Com a notícia, muitas pessoas desanimaram de seguir com a programação do evento para a tarde, que previa uma caminhada até as trincheiras para homenagem aos mortos no massacre. Apenas cerca de 20 pessoas caminharam até o local. É de se considerar que muitas pessoas, tendo ou não simpatia pelo presidente, vão à comemoração com grande expectativa de vê-lo.

$\mathrm{Na}$ trincheira em Kuruyuki, os presentes formaram um círculo em que todos se viam. $\mathrm{Na}$ ocasião, agradeceram aos parentes guerreiros que morreram em nome do seu povo. Felipe Román, que tomava frente do momento, pediu que os líderes refletissem sobre a busca da Terra sem Mal. Foram recordadas as viagens que os guaranis fizeram entre as serras do Chaco. Muitas das vezes, as incursões se justificam pela luta pela terra.

$\mathrm{Na}$ verdade, apesar de existir uma programação oficial da APG com a distribuição das atividades da programação ao longo dos dois dias, na prática, os horários são mais livres, mesmo sem imprevistos. Durante o evento, nas poucas ruas de Ivo havia mais movimento que o habitual, além dos muitos carros e micro-ônibus. Algumas pessoas aproveitavam para montar suas barracas e vender artesanatos e comida: churrasco, empanada, sopas, chicha, batatas e milhos cozidos. Já outras famílias, aquelas residentes em Ivo, preparavam as mesmas coisas e serviam gratuitamente ao público. Paralelamente, outras barracas expunham livros, CDs, uma diversidade de produtos da APG e de cooperativas. Além disso, na ocasião, estavam expondo mel de abelhas de criação dos guaranis e os tecidos feitos por cooperativas de mulheres guaranis. Notava-se que as pessoas estavam dispersas em grupos de amigos, familiares, jovens, lideranças, mulheres: conversando, discutindo, planejando, prometendo, cantando, dançando, festejando. Kuruyuki constitui-se paralelamente uma festa cívica e outra descompromissada. 
Depois de visitar o ossuário no cemitério com os restos mortais dos guerreiros do massacre, conheci os novos prédios da Unibol e voltei com Antonio para a cidade de Camiri, uma vez que teríamos de voltar no outro dia para os atos cívicos de Kuruyuki. Deve-se destacar que a maioria das pessoas foi embora sem pretensões de retornar no outro dia, até porque muitas não tinham condições, uma vez que não tinham transporte planejado para o ocorrido. Nessa comemoração as pessoas foram transportadas em micro-ônibus das prefeituras com recursos da APG e também de parcerias com Teku e CIPCA.

No dia seguinte, 29, a partir da mesma logística de transporte, Antonio e eu voltamos a Kuruyuki para assistir aos discursos políticos e à inauguração das instalações da Unibol. Estavam presentes no ato cívico as autoridades zonais e municipais, lideradas pelo mburuvicha guasu de Ivo, o presidente da APG Nacional, Faustino Flores, o presidente do Consejo de Capitanes de Chuquisaca (CCCH), Celestino Rojas, o representante dos guaranis da Argentina, o prefeito de Macharetti, Reynaldo Maraz. Além do governador de Chuquisaca, Esteban Urquizo, os ministros Carlos Romero, Claudia Peña e Nemesia Achacollo e o presidente do Estado Plurinacional, Evo Morales.

Faustino Flores, em seu discurso, agradeceu a presença do presidente Evo Morales e demandou a ele a declaração de Kuruyuki como patrimônio histórico imaterial e feriado em memória dos indígenas das terras baixas. De modo geral, cobrou a implementação dos direitos garantidos na Constituição Política do Estado, principalmente seus pontos relativos à autonomia dos povos indígenas. Ademais, recordou os temas pendentes entre a plataforma da APG e o governo: o projeto de lei do marco de consulta, a lei agrária e a descentralização dos recursos do Fundo Indígena. Por outro lado, o presidente do $\mathrm{CCCH}$ aproveitou a oportunidade para convidar o presidente Morales para a comemoração da morte do guerreiro guarani Apiaguaiki Tumpa, no dia 29 de março, em Monteagudo, na província de Hernando Siles, Departamento de Chuquisaca, $98 \mathrm{~km}$ de Camiri.

Depois do ato cívico de Kuruyuki, autoridades e o reduzido público caminharam aproximadamente $1 \mathrm{~km}$ até as novas instalações da Unibol. Trata-se de 17 edifícios construídos, para sala de aula, laboratórios, salas administrativas, auditórios, biblioteca, banheiros e refeitório, porém ainda sem eletricidade, água ou qualquer mobília. Os recursos para a construção da universidade são oriundos do Programa Bolivia Digna - Educación, financiado por meio de projeto de cooperação internacional entre Holanda, Suécia, Dinamarca 
e Espanha ${ }^{25}$, administrado pelo Ministerio de Educación. Fundada em agosto de 2008, funcionou em prédios alugados no centro da cidade de Macharetí, apenas em janeiro de 2014 foi transferida para as novas instalações em Kuruyuki. Inclusive, a mudança oficial aconteceu na comemoração de 2014, oportunidade em que também foi empossada a nova diretiva da APG Nacional.

\subsection{Os lugares de memória}

A partir da primeira comemoração de Kuruyuki, as comunidades de mesmo nome e Ivo começaram a se constituírem enquanto espaço da memória do massacre. Nesse sentido, com o passar dos anos, foram (re)instalados cada vez mais equipamentos culturais em torno da comemoração. Pensando em Kuruyuki, a APG demandou no local desde palanque para as apresentações até universidade. Assim, a memória do massacre é materializada na região por meio da(o): 1) revitalização de uma das trincheiras do massacre; 2) cruz em homenagem aos mortos no massacre, fincada na porta da Iglesia San Boaventura; 3) um ossuário na praça central do cemitério da comunidade; 4) terreno/pátio com palanque de concreto coberto; e 5) universidade indígena que leva o nome do líder do massacre, Apiaguaiki.

\footnotetext{
${ }^{25}$ A relação dos guaranis com a Espanha será discutida no fim deste capítulo.
} 
Representação da Comunidade de Ivo e seus principais espaços na comemoração de Kuruyuki

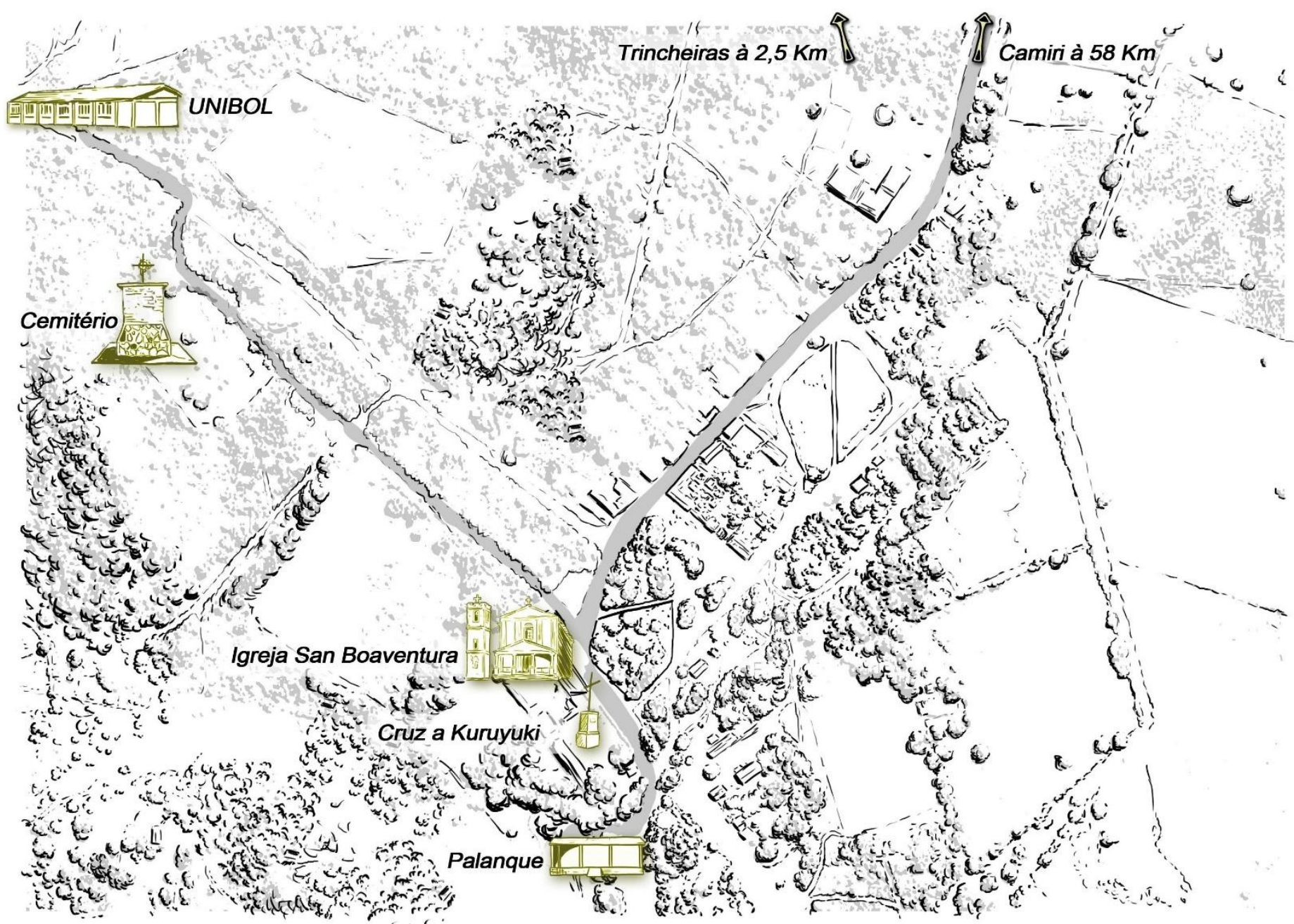

Fonte: Elaborada pelo desenhista Ciro Gonçalves. 
Entendendo Kuruyuki como um ritual, uma de suas etapas consiste em um momento sagrado em uma das trincheiras "revitalizada" para a comemoração do massacre, conforme dito anteriormente (Figura 27). Esta foi estabelecida em 1992, poucos metros de onde, na mesma época, escavaram em busca dos ossos dos mortos (Figura 20). Consiste em um raso buraco no chão demarcado por um círculo formado por pedras de diferentes tamanhos. Debaixo de uma árvore, a área não tem vegetação, já que frequentemente há pessoas no lugar. A etapa desse ritual é conduzida por um sábio guarani, iyaa pia, que guia um momento de reflexão em prol dos espíritos dos guerreiros que morreram no enfrentamento. Felipe Román, por vários anos, se encarregou dos discursos nas trincheiras.

Depois das trincheiras, caminhando cerca de 200 metros, encontramos a área que escavaram, em 1992, em busca dos restos mortais dos guerreiros de Kuruyuki. Em campo, na comemoração de 2013, eu não conheci essa área, pois Antonio não me levou até lá. Conheci apenas no segundo campo, em setembro, quando Felipe Román me acompanhou em uma visita às comunidades de Kuruyuki e Ivo. A área da escavação coincidia com um grande buraco - resultado do frequente processo erosivo na região -, de modo que não se pode perceber de imediato que se trata de uma área escavada. Contudo, Felipe estava bastante entusiasmado em me contar toda a história e me mostrar os diferentes tipos de cerâmicas que íamos encontrando. Ainda, notei que existiam restos de velas próximos aos arbustos, sobre isso, Felipe contou que os guaranis das comunidades vizinhas cultuam entre as escavações em prol dos familiares que morreram em 1892.

Felipe me disse que, a partir de 1990, no contexto de mobilização para a primeira comemoração e grande marcha, segmentos da igreja católica, ONGs e antropólogos iniciaram a assessorar os guaranis no empreendimento de escavação, que começou meses antes do evento comemorativo. Fêmures e outros ossos foram encontrados, colocados em urnas funerárias, levados para a Catedral de Camiri - Iglesia San Francisco de Asís -, em função de uma grande missa campal. Depois de abençoados, retornaram com os ossos para Ivo, onde foram depositados em um ossuário na praça central do cemitério da comunidade, feito especialmente para aquela ocasião, em janeiro de 1992.

Em conversa com o sociólogo guarani Milton Charangay, na época secretário de autonomias da APG Nacional, percebi que existem controvérsias sobre se os ossos figurados em Kuruyuki são de fato dos guerreiros indígenas do enfrentamento. Milton Charangay me disse, por exemplo, que não foi feito nenhum estudo com os materiais encontrados, não havia 
arqueólogos na empreitada. Além do mais, lembrou que os ossos podem ser de outros animais ou de humanos mortos no contexto da Guerra do Chaco. Segundo ele, durante essa guerra também houve conflitos e mortes na região. Explorar esta questão me demandaria um bom tempo na comunidade de Ivo e Kuruyuki, conversando com sábios e anciãos.

A APG, em 1997, construiu em um descampado na comunidade Ivo um edifício de concreto, coberto com telhas de amianto, com duas partes: um salão (que estou chamando de palanque) aberto com vista para um grande campo com mais ou menos $100 \mathrm{~m}^{2}$, descoberto e com poucas árvores ao redor, que recebe o público da comemoração (Figuras 26 e 30). Ligado ao salão (palanque) existe um pequeno cômodo coberto e fechado, que serve de depósito e sala de reuniões. Cotidianamente, este edifício é utilizado para as atividades da APG comunal de Ivo (reuniões, cursos etc.), porém sua finalidade principal é ser palco anualmente da comemoração do massacre. Nas paredes do fundo do salão, de frente para todo o público do evento, existe a seguinte frase pintada: La lucha hoy no será más con arco y flecha, sino con pluma y papel. Posteriormente, ainda neste capítulo, comentarei a expressão.

Na comunidade de Ivo, outra referência ao massacre é a cruz instalada na ocasião da comemoração de Kuruyuki de 1997 (Figura 24). Na placa da cruz está inscrito que se trata de homenaje a nuestros [dos guaranis] hermanos caidos en la masacre de Kuruyuki, en la defensa de nuestro [dos guaranis] territorio, cultura e identidad. Esta cruz está fincada em frente à Iglesia de San Buenaventura, por sua vez, inaugurada também em 1992. Sua paróquia é vinculada ao Vicariato Apostólico de Camiri.

A universidade é outro espaço de alusão ao massacre no processo de construção da nação guarani (Figura 28). A partir do Decreto Supremo 29664, do dia 2 de agosto de 2008, o presidente Evo Morales criou três universidades indígenas - Unibol: Aymara, Quechua e Guaraní y Pueblos de Tierras Bajas - como entidades comunitárias e interculturais de educação superior pública. A sede desta terceira Unibol localiza-se na comunidade de Ivo e recebe o nome do grande líder guarani morto em decorrência de Kuruyuki: Unibol Guaraní y Pueblos de Tierras Bajas "Apiaguaiki Tüpa”. Ela começou a funcionar provisoriamente, em 2008, no município de Macharetti, e só a partir de 2014 foi transferida para o campus recéminaugurado em Ivo, conforme já sinalizei.

A universidade oferece graduação e certificados de técnico superior em Engenharia de Petróleo e Gás, Engenharia Florestal, Piscicultura, Medicina Veterinária e Zootecnia. Além de levar o nome do grande guerreiro de Kuruyuki, o campus foi construído nos pés de uma serra, 
região do antigo povoado de Murukuyati, onde Apiaguaiki viveu com sua família e foi um dos poucos sobreviventes de um ataque a mando do fazendeiro Pedro Zárate, que matou sua mãe, deixando-o órfão.

\subsection{Os símbolos de Kuruyuki}

A comemoração de Kuruyuki é o momento em que os símbolos oficiais da nação guarani são evidenciados, isto é, aqueles instituídos pela APG. Desde 1992, esta organização indígena investe na institucionalização de códigos nacionais. O Estatuto da Autonomía Guaraní Charagua Iyambae reconhece como seus símbolos a bandeira e o hino da Nação Guarani, a frondosa árvore toborochi (Chorisiaspeciosa), a flor de carnaval (Habranthus Tubispathus), o guanaco (Lama guanicoe), o tacú y sumanija (uma espécie de pilão de madeira acompanhado de vaso do mesmo material), o Avati (milho - base da cultura alimentar guarani) e o "trem da integração". Bandeiras, hinos, músicas e artesanatos são eficazes marcadores identitários entre quaisquer grupos sociais. Em Kuruyuki, os guaranis manipulam constantemente esses elementos.

Em uma das fases do ritual da comemoração é apresentado o hino à Kuruyuki, produzido pela Escuela TekoveKatu ${ }^{26}$ especialmente para a comemoração de 1992 (Figuras 38 e 39). A partir de então passaram a proferir o hino nos anos seguintes. Em 2002, começaram a apresentar o canto da nação juntamente com a Orquesta de Palmarito, da mesma escola. Abaixo, a letra do Himno a Kuruyuki:

$$
\begin{gathered}
\text { Kerełmba reta guaraní } \\
\text { oeya tafkuere yandepfape } \\
\text { oepł vaera yande fvf } \\
\text { oeya płape yeyora } \\
\text { Ñande mbaendua Kuruyukire } \\
\text { ngaraayema ñande amłrf } \\
\text { ani ñandeaki yandepłape } \\
\text { Ñande rał reta pe arakua } \\
\text { yande reko reta oyovake } \\
\text { metei rami motirore } \\
\text { jaeño tekove guaraní }
\end{gathered}
$$

Miles de heroes guaraní dejaron sello al corazón por defender su nación en la trinchera libertad

Ejemplo en Kuruyuki está nunca jamás se rendirá no nos cansemos de marchar la sangre vibra el corazón

Por nuestro hijos educación por la cultura la igualdad con el trabajo y la unidad que viva siempre guaraní

\footnotetext{
${ }^{26}$ Localizada na cidade de Gutiérrez, nas margens da Ruta 9, entre Santa Cruz de la Sierra e Camiri.
} 
Como podemos perceber por meio da letra do hino, a luta pela sobrevivência entre os guaranis é apresentada como um processo contínuo que faz parte do modo de ser guarani, e inclui ser guerreiro. Resistiram até Kuruyuki, é o exemplo de enfrentamento, apesar da derrota. Na segunda estrofe, percebemos que a consciência nacional, construída a partir da memória do massacre, projeta uma sociedade mais justa. Em conversa com Damary, professora indígena em Camiri, fui informado de que muitos adolescentes e crianças guaranis sabem a letra do hino. Ela me contou que em algumas escolas indígenas da região eles aprendem o hino, pois este consta no material didático produzido e distribuído pela Teko Guarani nas escolas indígenas da região. Em setembro, encontrei um pequeno cartaz com o hino na biblioteca da Escuela Superior de Formación de Maestros Pluriétnica del Oriente y Chaco, conhecida como Escola Normal de Camiri.

Além da dimensão cívica e política, Kuruyuki é uma festa, um evento com aspectos estéticos e recreativos. A música guarani, habitual no Arete Guasu, também está presente na comemoração. Com diferentes melodias, são produzidas com instrumentos musicais próprios, como a tambora, a flauta e bombo. Durante o dia da comemoração, na comunidade de Ivo em suas poucas ruas, na área do palanque ou próximo às barraquinhas de comida e artesanatos -, é comum ouvir os sons desses instrumentos. Estes servem como trilha sonora da festa, pois é comum vermos crianças, adolescentes e músicos profissionais tocando esses instrumentos durante todo o evento.

Dos agudos trinados da flauta guarani a música ganha a sensação de espaços amplos, do bumbo e o tamborete a música obtém o clima de folia e cortejo. Similar às alegrias do pife (pífano) de bambu dos sertões nordestinos do Brasil, a ambiência chaquense da melodia impede a confusão geográfica: estamos entre os guaranis na Bolívia. Ademais do som da música, grandes alto-falantes emolduravam a cena em Ivo, chiando e travando enquanto o mestre de cerimônias aquecia e testava o microfone, quando alguém discursava.

Os guaraniólogos clássicos, por exemplo, Cadogan (1992), perceberam o papel da música na cultura guarani, tanto que fizeram parte de seus estudos os cantos guaranis. Ademais, música e dança na cultura guarani estão diretamente relacionadas com o Arete Guasu, a festa grande. Assim como em Kuruyuki, essa festa é caracterizada como um espaço de reciprocidade, solidariedade e de unidade social. Recordar o passado e reencontrar-se com a alma de parentes falecidos, sobretudo anciãos, é um dos objetivos do Arete Guasu. O 
mesmo acontece nas comemorações de Kuruyuki, em especial, o momento de reflexão nas trincheiras.

Mauss (2003), em seu clássico o Ensaio sobre a Dádiva, se propõe a responder à seguinte questão: o que faz com que as sociedades arcaicas mantenham obrigações de prestações recíprocas? Para ele, nessas sociedades existe uma relação de trocas, que é estruturada por três momentos: dar, receber e retribuir. As trocas não são ações inertes, pois elas têm almas. Sendo assim, elas se diferenciam da economia monetária, estimulada pelo interesse material da troca.

Muitas das vezes, nas sociedades ocidentais, as relações econômicas são marcadas pelo individualismo e impessoalidade, sendo que em muitas sociedades não ocidentais o sistema econômico é predominado pela moral do dom. Por sua vez, o dom representa a relação dupla de dar e receber. Como já comentei, o sistema econômico guarani é orientado pelas relações de reciprocidade, ideia que encontra expressão na palavra mborerekua (MELIÁ, 1988). Segundo Melià (1988), entre os guaranis a reciprocidade supõe que alguém oferece uma dádiva de modo gratuito e com vontade de agradar o próximo. Como a dádiva não exige um retorno imediato e equivalente, cria uma situação que motiva a restituição da dádiva. Sobre a mborerekua, uma das suas melhores expressões é a capacidade de convidar, o convite entre os guaranis é uma instituição central no sistema de reciprocidade (MELIÁ, 1988).

Nas festas guaranis, seja na comemoração do massacre ou na Arete Guasu, a chicha de milho e o trabalho para seu preparo são motivações para constantes trocas. O consumo da chicha, durante as festas ou na vida cotidiana, além de significante, serve de mediação no sistema de prestações recíprocas, que está longe dos benefícios econômicos monetários.

Os recursos para organização das comemorações são escassos, todavia as capitanias, juntamente com a APG Nacional, se desdobram a fim de angariar: transporte até Ivo, suporte para as apresentações culturais e discursos, alimentação, além da chicha. Estas questões são viabilizadas a partir de parcerias com prefeituras, CIPCA, Teko Guarani, CEPOG, Igreja Católica e comunidades.

A bandeira da nação guarani foi criada em 2006 pela Asamblea del Pueblo Guaraní (Figuras 29, 32 e 40). Ela possui três cores: cor "café", que representa terra e território; verde, que representa os componentes da natureza; e o azul, que significa o céu e o ar. Terra, natureza e ar: para os guaranis, ninguém pode viver sem eles. A partir de então, começaram a 
exibir a bandeira guarani em eventos, marchas e, sobretudo, na comemoração de Kuruyuki. Ademais, atualmente, a marca visual da bandeira é usada como marca d'água em documentos expedidos pela APG Nacional.

Para além de Ivo e Kuruyuki, referências ao massacre de uma nação guerreira foram construídas. Na cidade de Santa Cruz de la Sierra existe uma estátua do Apiaguaiki na rotatória do Segundo Anillo, próximo a Via La Guardia (Figura 17). Em Camiri, a estátua é imponente, o guerreiro com uma flecha em posição de ataque. Localiza-se na Avenida Petrolera com 24 de Septiembre e foi inaugurada no dia 7 de novembro de 1987 (Figura 18).

\subsection{As autoridades políticas}

A comemoração de Kuruyuki representa um dos poucos momentos em que as lideranças guaranis de diferentes capitanias conseguem se encontrar e fazer percebido a coletividade do movimento nacional, tornando-se visível para os karai e o público guarani de modo geral.

A cada ano o evento ganhou mais significado e divulgação entre as pessoas da província da Cordillera. Ademais, o evento promove a presença de grandes autoridades políticas, incluindo os presidentes da República Jaime Paz Zaroma (1992) e Gonzalo Sánchez de Lozada (1994), representantes do MAS (2005) e o presidente Evo Morales (2008, 2009, 2012, 2013, 2014).

Com a presença das personalidades estatais na comemoração em Ivo, torna-se necessário, segundo a lógica do Estado, a participação das forças militares para garantir a segurança dessas autoridades (Figura 36). A partir de fotos das comemorações anteriores e de 2013, da qual participei, veem-se filhas de soldados, alguns armados, que formam uma barreira próxima aos convidados ilustres. No entanto, isso compõe um cenário que se mostra aparentemente contraditório, já que fora o próprio Exército republicano que massacrou, no mesmo local, os guaranis no fim do século XIX. Todavia, este paradoxo é compreensível, uma vez que os guaranis atuais traduzem/ressignificam a relação conflitiva com essa instituição em termos de articulação, em que suas próprias ações são ressignificadas. A atual presença amigável do Exército em Kuruyuki denota uma metafórica conquista guarani, por meio do diálogo com as forças estatais. 
Em relação à organização indígena, as comemorações de Kuruyuki também são apresentadas como cerimônias inaugurais nas quais as novas lideranças e as autoridades políticas eleitas prestam seus juramentos a cada evento. Representam um dos poucos momentos no ano em que a realidade coletiva do processo de nação guarani é visibilizado às audiências karai e guarani de modo geral. Enquanto espaço da política, Kuruyuki é um momento de diálogo interétnico público e também de encontro das bases, bem como de autorrepresentação coletiva e como os guaranis falam de seu passado.

De acordo com Gustafson (2009), muitos karai temem que a mobilização dos guaranis seja precursora da violência, da desordem. Contudo, ao atermos a essas mobilizações, percebemos que os guaranis performatizam ordem e nacionalismo - no sentido amplo - e lealdade. A comemoração de Kuruyuki reconhece o poder (militar, religioso, civil e a ONG) a partir do convite e da presença do Exército, da Igreja Católica e das ONGs entidades com profunda relação histórica com os guaranis.

Por último, é importante considerar que os guaranis, a partir da APG, também modificaram suas próprias reivindicações ao longo das comemorações, dando voz a interesses compartilhados, algumas vezes, com os karai, especialmente em relação ao sentimento regionalista do Chaco, que, de certa maneira, une os guaranis aos não indígenas.

\subsection{Guaranis versus Espanhóis}

Os guaranis, caracterizados como combativos à colonização, conseguiram conter vários séculos de seguidas ofensivas simbólicas e físicas que visavam roubar suas terras. Inclusive, nesse contexto, devido à belicosidade guarani, a Coroa espanhola chegou a anunciar guerra a eles. Isto gerou repercussões recentes entre os guaranis, no âmbito do processo de afirmação nacional.

Em relação ao domínio espanhol na cordilheira andina, a conquista das terras baixas foi atrasada pela resistência indígena. Já tendo estabelecido unidades administrativas na parte ocidental, apenas em 1561 os espanhóis fundaram a cidade de Santa Cruz de la Sierra, porém a região do Chaco lutou mais ainda, resistiram aos espanhóis durante todo o período imperial, contudo, foram aniquilados décadas depois pelos criollos, no âmbito da parceria entre os fazendeiros da região e o Exército republicano. Todavia, anteriormente, os indígenas dessa 
região, majoritariamente guarani chiriguano, protagonizavam ataques esporádicos às bases hispânicas.

Evidentemente que a noção de fronteira típica do Estado moderno europeu não era do conhecimento dos guaranis nos fins do século XVI. Todavia, eles recordam que o Rei Felipe II, por meio do designado administrador colonial ${ }^{27}$ Francisco de Toledo, declarou formalmente guerra contra os guaranis em 1584 (COMBÈS, 2005a), depois de fracassadas expedições contra esses indígenas. Trata-se de um acontecimento histórico singular porque não existem outros registros de Colônias que tenham oficializado guerra contra os indígenas nas Américas.

Diversas vezes, em conversas informais com Felipe Román, ele fazia alusão ao acontecimento. Apesar de os libertários “expulsarem” os espanhóis da região, em 1825, com a proclamação da República pelos criollos, naquela conjuntura nada foi reparado, por parte da Espanha, em relação à declaração de guerra.

Todavia, Felipe me disse que, em 1995, o Rey de España ${ }^{28}$ Juan Carlos I remeteu uma carta à APG com proposta de paz. Na época, Bonifacio Barrientos, capitão da APG Zonal de Alto y Bajo Izozo, alegou que a iniciativa espanhola foi rejeitada em reunião entre capitães da APG (EL PAÍS, 1999). Para Román, a proposta de paz foi recusada por alguns capitães, pois estes demandavam o ressarcimento dos danos causados nos enfrentamentos, dos roubos, a expropriação do território, mortes e aniquilamento dos bens culturais.

Em 1999, um projeto piloto de combate à incidência da doença de Chagas ${ }^{29}$, financiado pelo governo da comunidade autônoma Valenciana, a Generalitat Valenciana e a Universitat Politècnica de València, e que apresentou bons resultados no território guarani da Bolívia, fez com a APG discutisse novamente o acordo de paz. O projeto colaborou para mudança de hábitos higiênicos e educativos dos guaranis, melhorando a qualidade de vida em algumas comunidades. No entanto, a APG não voltou atrás no acordo de paz ao Rey de España, manifestando na comemoração de Kuruyuki de 1999. Na ocasião do evento, leu-se uma carta do Rey de España para os guaranis, dizendo que era preciso "cerrar las heridas de la

\footnotetext{
${ }^{27}$ Trata-se da figura do "virrey", função administrativa própria da Colônia espanhola na América, responsável por gestão territorial da província ou país.

${ }^{28}$ Atualmente, no Estado espanhol, Rey de España é o chefe do Estado. Dentre outras responsabilidades constitucionais, cabe a essa figura representar o Reino da Espanha e, também, ser comandante das Forças Armadas.

${ }^{29}$ A doença de Chagas é um dos principais problemas de saúde pública entre os guaranis na Bolívia.
} 
historia y avanzar hacia un nuevo periodo de amistad y colaboración recíproca" (EL PAÍS, 1999).

O fato histórico da declaração de guerra aos guaranis embasa o atual discurso do movimento guarani na Bolívia de que eles nunca foram submissos à Coroa hispânica, de que é uma nação consolidada e resistente. Além do mais, a situação recente de acordo de paz com a Espanha colabora com o argumento de que existe um processo de construção nacional guarani em curso na Bolívia. Se considerarmos a Espanha como uma grande nação, assim como os guaranis. A situação acima nos remete a um debate acerca das relações internacionais ${ }^{30}$ guaranis. Esta reflexão é importante para termos dimensão do quanto a afirmação nacional guarani os coloca em posição de negociação direta com atores estatais e internacionais. Entre os guaranis, organizar-se em termos nacionais amplia sua capacidade de força política e articulação diante de instituições estatais bolivianas e internacionais.

Ainda, sobre as relações guaranis versus espanhóis, em 2013, quando o Estado espanhol fechou seus espaços aéreos ao avião do presidente boliviano Evo Morales, a APG fez um pronunciamento público por meio de uma carta de repúdio divulgada em sua rádio $\tilde{N}$ anduti $^{31}$ e outros meios de comunicação. Na carta, a nação guarani exige ações judiciais contra o governo espanhol, além do pedido de desculpas públicas pela agressão, que eles consideram não só para os bolivianos, mas para toda América Latina. Ainda, a carta expressa a preocupação dos guaranis em relação à vulnerabilidade dos direitos internacionais para a Bolívia, além de apoiar o presidente Evo Morales.

\subsection{Os intelectuais da nação guarani}

Na Guatemala, Warren (2010) observou que a presença de intelectuais públicos maias na defesa de seus interesses coletivos representa uma transformação nesse movimento indígena. A partir do processo colonial, os intelectuais tradicionais, isto é, aqueles preocupados com as dimensões religiosas, xamânicas, concentraram seus esforços na construção de espaço morais para a celebração da conexão dos indivíduos com sua comunidade, seus ancestrais e sua religião indígena. Entre os guaranis, esse momento de

\footnotetext{
${ }^{30}$ Aqui, relações internacionais não se referem ao campo sobre as relações entre Estados - que então deveria se denominar "relações interestatais" -, mas sim à relação entre nações, no caso: a nação guarani x nação espanhola.

${ }^{31}$ A rádio Ñanduti é de propriedade da Asamblea del Pueblo Guaraní (APG) e integrante da Red Patria Nueva.
} 
comunicação das lideranças atuais com seus guerreiros ancestrais, mortos no massacre, ocorre em Kuruyuki durante o ritual nas trincheiras. Assim, mesmo na atualidade, esse é um dos papéis do intelectual guarani, conhecido como arakuaa iya, que significa sábio, em guarani.

Todavia, em interação com as agências da colonização, igreja, fazendeiros etc., os intelectuais tradicionais começam a desenvolver uma visão de mundo compartilhada, transitando entre o mundo indígena e o karai, no caso dos guaranis. Na região do Chaco, a partir de 1970, muitos sábios e lideranças guaranis se instrumentalizavam em espanhol e, na educação formal de modo geral, por meio da formação religiosa ocidental, seja católica ou neopentecostal. Acompanhando a história de vida de Antonio Mendez, Elio Ortiz e Felipe Román, meus três principais interlocutores e que são considerados intelectuais guaranis, noto que todos tiveram a oportunidade de estudar a partir da formação teológica. Também estabeleci diálogo com o intelectual guarani Elias Caurey, porém este trabalha no governo nacional em La Paz, onde reside atualmente. Não nos encontramos pessoalmente, mas conversamos por meio das redes sociais virtuais.

Atualmente, os intelectuais indígenas não atuam apenas na dimensão tradicional, no elo entre os ancestrais e o presente. O número crescente de lideranças com considerável conhecimento sobre a cultura de seu povo e dos seus direitos indígenas conforma os chamados intelectuais públicos, isto é, aqueles que se envolvem em lutas locais em defesa de seu povo. Outra característica dos intelectuais públicos é que frequentemente inspiram os líderes a trabalhar pelo ressurgimento cultural em diversas comunidades (WARREN, 2010).

Tanto Felipe Román, 65 anos e Antonio Mendez, 72, quanto Elio Ortiz, 46 e Elias Caurey, 37, trabalham profissionalmente com a cultura guarani. Além de traduções e livros de $\mathrm{EIB}$, frequentemente produzem textos escolares e materiais de treinamento de professores, sobretudo, para formação de profissionais interculturais. Ademais, principalmente Felipe Román, têm trabalhado bastante na revitalização do guarani no âmbito de programas radiofônicos em guarani.

Outra dimensão importante dos intelectuais públicos indígenas é que eles têm importante papel na divulgação da cultura guarani no seu processo de construção nacional. Eles frequentam convenções, reuniões nacionais e até internacionais, espaços locais de discussão da política. Elio Ortiz e Felipe Román recentemente estrearam no cinema nacional boliviano, interpretando dois personagens guaranis em contato com um karai, representado pelo próprio diretor do filme, o paceño Juan Carlos Valdivia (Figuras 44 e 45). Trata-se do 
filme Yvy maraey - Tierra sin $\mathrm{Mal}^{32}$, seu tema principal é a interculturalidade, renova um diálogo da cultura ocidental com as culturas indígenas. O filme aposta em um novo indigenismo na Bolívia, em que o cinema propõe uma nova forma de pensar, ver e falar com o indígena nesse país. Antropologicamente, esta perspectiva valoriza as agencialidades indígenas, ou seja, destaca iniciativas e valorizações guaranis na relação com o karai. O massacre de Kuruyuki é abordado no filme, inclusive, cinco anos antes da estreia do filme, Valdivia procurou Ortiz com a ideia original de reconstituir cinematograficamente o massacre.

Além de atuarem como atores, Ortiz e Román também atuaram na produção do filme. O primeiro escreveu o filme junto com Valdivia, era um consultor da cultura guarani, já que esse filme trata desse povo. Já Román trabalhou na produção local nas gravações nas comunidades, no recrutamento de outros atores e na organização da estreia do filme, quando eu estava presente em Camiri. Na ocasião fomos até a comunidade de Ivo e Kuruyuki conversar com os capitães das comunidades para negociar a estreia do filme, com exibição no espaço público em frente à Iglesia San Buenaventura, onde está a cruz em homenagem a Kuruyuki. Além do mais, a estreia do filme aconteceu no dia 12 de outubro, quando se comemora o Día de la Descolonización en el Estado Plurinacional de Bolivia ${ }^{33}$.

A partir da exibição do filme em festivais, os intelectuais públicos da nação guarani Ortiz e Román começam a conceber entrevista para os meios de comunicação locais e a viajar em função da exibição do filme em festivais. Desde sua estreia o filme foi já premiado e exibido nos seguintes festivais: Melhor Desenho de Som $\left(35^{\circ}\right.$ Festival Internacional del Nuevo Cine Latinoamericano de la Habana); exibição no Festival Internacional de Cine de Mar del Plata (Argentina) e na quarta edição do Festival Pachamama - Cinema da Triple Fronteira (Rio Branco, Acre). Será exibido também no dia 16 de outubro no I Colóquio do LAEPI, em Brasília. Esses são momentos da divulgação internacional da cultura guarani para o exterior por meio dos seus intelectuais.

Felipe Román nasceu na comunidade de Kaipepe no município de Charagua, e apresenta muita vitalidade e disposição em intervir em favor do seu povo e, sobretudo, em pesquisar sobre a cultura guarani e sua interculturalidade. Juntamente com outras lideranças guaranis bolivianas, já fez viagens a comunidades guaranis no Paraguai e no norte argentino

\footnotetext{
${ }^{32}$ Link para o trailler: 〈http://www.youtube.com/watch?v=wmb5BDLb1vA>.

${ }^{33}$ O presidente Evo Morales Ayma promulgou a partir do Decreto Supremo de 12 de outubro de 2011.
} 
para "assessorar" organizações e realizar curas. Román, assim como a maioria dos sábios guaranis, tem forte capacidade de influência nas comunidades, apresentando consolidado diálogo com os guaranis de modo geral.

Elio Ortiz, além da formação de liderança comunitária a partir da Igreja Católica, graduou-se em comunicação em Santa Cruz de la Sierra e, quando faleceu no dia primeiro de agosto, estava prestes a concluir uma graduação em antropologia em Cochabamba. Elias Caurey, por sua vez, é sociólogo e antropólogo de formação. Todos eles possuem muitas publicações sobre a nação guarani. Um dos últimos livros de Caurey leva o seguinte título: Nación Guaraní. Namae Nande Rekore: Una mirada a nuestro modo de ser (ensayos socioantropológicos), 2013.

Além das publicações, do filme, da atuação na promoção do ressurgimento cultural e na divulgação da cultura guarani a partir de encontros, reuniões, entrevistas, os intelectuais públicos, no processo de construção da nação guarani, também atuam na administração pública do Estado Plurinacional ou em iniciativas da sociedade civil. Caurey é consultor na Coordinadora Nacional Comunitaria dos Consejos Educativos de Pueblos Originarios (CEPOS), em La Paz, responsáveis pela elaboração e desenvolvimento de políticas educativas interculturais e plurilíngue. Em seu ofício, trabalha com assessoria e consultoria da cultura guarani. Assim como Ortiz, quando em 2009 e 2010 esteve como coordenador de projetos sobre justiça indígena nas terras baixas no Viceministerio de Justicia Indígena Originario Campesina, também em La Paz. Em consequência desse trabalho, Ortiz produziu e publicou uma das principais referências sobre justiça comunitária na Bolívia: Justicia Comunitaria Guaraní (2009), também em coautoria com Caurey.

Por sua vez, Antonio Mendez atuou como consultor na elaboração do Diccionario etimológico y etnográfico de la lengua guaraní hablada en Bolivia (Guaraní-Español), de 2011, também de autoria de Ortiz e Caurey. Mendez, originalmente, é da Capitanía del Alto y Bajo Isoso, porém, atualmente, vive na cidade de Camiri, para onde migrou, segundo ele, para dar oportunidade de estudo para suas duas filhas, que, atualmente, são professoras indígenas. Em Camiri, Mendez criou a Fundación Yeporaka - Centro de Investigación Antropológica Guaraní (que funciona em um cômodo da sua casa), já desenvolveu projetos de desenvolvimento produtivo em comunidade, prestou assessoria em pesquisas, inclusive já acompanhou o trabalho de campo de vários cientistas sociais em Território Guarani. Hoje, em função de problemas de saúde, Mendez apenas mantém uma biblioteca e arquivos na instituição. 
Em relação à comemoração de Kuruyuki, em geral, os arakuaa iya Román e Mendez participam de forma diferente dos outros dois intelectuais mais jovens, Ortiz e Caurey. Os dois primeiros, como já sinalizei, atuam na etapa do ritual nas trincheiras, quando religiosamente os arakuaa iya guiam os presentes a uma dimensão para interação com forças espirituais dos guerreiros massacrados, que, segundo Román, revitaliza a luta política da nação guarani. Já Ortiz e Caurey recepcionam as autoridades políticas, as lideranças comunitárias e os convidados da sociedade civil. De uma forma geral, todos eles se envolveram na organização do evento, sobretudo nas primeiras edições.

A implicação metodológica de fazer trabalho de campo entre os intelectuais indígenas é saber lidar com "informantes informados", ou seja, interlocutores que apresentam uma perspectiva nativa da própria cultura, mas também conhecem relativamente a literatura histórica e antropológica sobre sua nação. Assim, em conversas ou entrevistas com essas pessoas, é comum eles citarem fontes e autores dos argumentos, referenciando documentos, artigos, livros etc. Ademais, sobre o perfil dos intelectuais públicos indígenas, conforme destacou Warren (2010), em geral, eles apresentam grande capital cultural - fluência no idioma nativo e do Estado, conhecimento de informática, espiritualidade indígena -, porém a maioria vive em circunstâncias econômicas modestas, com reduzido capital econômico.

Por fim, é importante destacar que a nação guarani tem outros intelectuais, a discussão neste trabalho se deu em torno dos quatro já citados, pois foi a partir deles que estabeleci minha experiência etnográfica.

\subsection{A Educação como projeto principal}

O tema da educação indígena é bastante debatido entre os guaranis. Na Bolívia, essa pauta se constituiu a partir da década de 1980 entre os guaranis, sendo estes vanguardistas no país em relação à luta pelos programas de Educación Intercultural Bilingüe (EIB). Inclusive, essa foi a principal questão apresentada nos discursos da primeira comemoração de Kuruyuki, em 1992. Nessa ocasião, "ponen en marcha el plan de alfabetización para adultos en toda la región guarani”, no entanto, a APG, desde 1989, já vinha implementando uma tímida educação com perspectiva de intermediação entre educação regular e uma alternativa.

A partir desse contexto, a frase La lucha hoy no será más con arco y flecha, sino con pluma y papel, do movimento indígena guarani, foi bastante difundida, conformando uma 
espécie de chavão etnopolítico guarani. Além de ter sido difundida em várias publicações didáticas produzidas pela Teko Guarani, a referida frase aparece em cartazes fotografados na Marcha de 1992, bem como em outras comemorações. Inclusive, em visitas a Ivo, comunidade em que acontece a comemoração, notei a expressão inscrita na parede do fundo do palanque destinado a discursos e apresentações culturais, tratando-se de uma posição em que praticamente toda a plateia enxerga a frase.

O tema da educação guarani na Bolívia está diretamente relacionado com a atuação da Teko Guarani. Esta é uma organização não governamental vinculada à APG, constituída em 1988, com sede em Camiri, preocupada com a educação e comunicação indígena. Ela produz materiais didáticos bilíngues, sistematiza e arquiva parte dos documentos da APG, até porque a comunicação organizacional é uma das fragilidades desta organização indígena ${ }^{34}$. Por sua vez, a Teko tem uma unidade de comunicação, que assessora as estratégias institucionais por meio da produção e difusão de programas radiofônicos emitidos pela emissora local (Rádio Parapetí), departamental (em convênio com a Rádio Santa Cruz) e na esfera nacional pela Red de Educación Radiofónica de Bolivia (ERBOL).

Ao mesmo tempo em que o movimento guarani se diferencia negando a cultura karai, ele reconhece que é necessário se instrumentalizar com o idioma europeu e optar por lutar por demandas de alfabetização, de educação intercultural bilíngue e, mais recentemente, por educação superior intercultural indígena. A partir da experiência etnográfica na comunidade escolar de Itanambikua, pude perceber, a partir da minha compreensão das razões pelas quais os pais mandavam suas crianças para minhas aulas de reforço, no contra horário das aulas regulares, que existe um incentivo, por parte deles e dos avós, para que os filhos estudem. Nesse contexto, escutei, por exemplo, frases como: "hijo mío debes estudiar y ser profesional, para que no seas como yo".

Nesse sentido, a educação tem o propósito de construir sujeitos intermediários, interculturais. A ideia é que, com a educação, os sujeitos possam decidir por eles mesmos, ser autônomos, defender seus direitos. Diante disso, podemos entender que o novo guerreiro guarani é aquele que estuda, adquire uma profissão e, idealmente, luta pela revitalização da

\footnotetext{
${ }^{34}$ Em campo na organização, pude perceber que eles não se preocupavam em guardar documentos institucionais, publicações referentes a eles, material produzido dos seus eventos. Quando estava lá, tive reuniões com a dirigente de comunicação da APG, Ena Taborga, a fim de poder ajudar na comunicação organizacional do movimento, mas infelizmente não avançamos nesse tema. Muitas vezes, eu requeria algum documento para a secretaria da APG ou para Ena Taborga e elas me orientavam a buscar na Teko Guarani ou em CIPCA, pois sabiam da existência, porém não tinham.
} 
sua cultura e melhoria da qualidade de vida nas comunidades. Isso é confirmado pela frase que citei antes: "a luta atual não é mais com arco e flecha, mas sim com papel e caneta". A valorização da educação como instrumento de emancipação é a nova estratégia (de guerra) da nação guarani para promoção da justiça e desenvolvimento da nação. 


\section{Conclusão}

\subsection{Reelaboração Cultural: História versus Cultura}

O antropólogo Sahlins (1987) constrói importantes contribuições para o diálogo entre a antropologia e a história, consequentemente é uma das principais referências na antropologia para o estudo das mudanças sociais na contemporaneidade. $O$ conceito antropológico de cultura é central para o estudo da história e vice-versa, isto é, qual a relevância da história para o estudo da cultura? Essa é uma das principais questões que Sahlins dedicou-se a elaborar. Segundo esse teórico,

o problema agora é de fazer explodir o conceito de história pela experiência antropológica da cultura. As consequiências, mais uma vez, não são unilaterais; certamente uma experiência histórica fará explodir o conceito antropológico de cultura - incluindo a estrutura (SAHLINS, 1987, p. 94).

Nesse sentido, Sahlins (1987) discute a relação entre estrutura e evento. A proposta do autor é que a estrutura, isto é, as relações simbólicas de ordem cultural, seja um objeto histórico. Nessa perspectiva, no desenrolar dos acontecimentos, ao interpretar o passado, as pessoas repensam suas categorias culturais, assim "um evento transforma-se naquilo que lhe é dado como interpretação. Somente quando apropriado por, e através do esquema cultural, é que adquire significância histórica. $\mathrm{O}$ evento é a relação entre um acontecimento e a estrutura" (idem, p. 15). Assim, para Sahlins (1987), a cultura é o uso do passado histórico como forma de produzir um presente.

Ao aproximarmos essa discussão a um contexto latino-americano, pois Sahlins (1987) elabora sua abordagem no contexto das ilhas do pacífico, Batalla (1987) diz que os indígenas, no México, reelaboraram muitos aspectos da cultura ancestral em torno das rebeliões indígenas. Muitas das vezes, os fatos históricos da colonização se convertem em um recurso fundamental que permite, por uma parte, manter vivas as lembranças do infortúnio e, por outro lado, colocar a etapa de submissão como uma situação transitória, algo reversível que poderá ser transformada com o triunfo da rebelião. Assim, entre os guaranis na Bolívia a volta ao passado se converte em um projeto para o futuro, que pode ser traduzida nos termos de luta política e resistência indígena diante das agências do Estado e da sociedade nacional. Os caminhos da resistência, segundo Batalla (1987), constituem uma intricada rede de estratégias 
que ocupam um amplo espaço nos esquemas culturais e na vida cotidiana dos povos indígenas. Mostrei que a comemoração de Kuruyuki é um exemplo.

Sahlins (2007) também tem discutido questões relativas ao modo como as culturas conduzem suas próprias historicidades. Nessa perspectiva, ele apontou que o sistema mundial, para além do processo de globalização, é ressignificado por diferentes categorias locais (SAHLINS, 2007). Atualmente, Kuruyuki, enquanto ação do movimento indígena guarani na Bolívia, é uma forma com que os indígenas lidam com a modernização, isto é, seriam estratégias locais para entrar na globalização. Além do mais, a partir disso os guaranis ressignificam as noções impostas pelo Estado, apropriando-se desses discursos como forma de acessar a cidadania e seus direitos.

A noção de história empregada converge com a ideia expressa nos escritos de Oliveira Filho (1999a, 1999b) sobre os povos indígenas do nordeste brasileiro: "A história é somente um veículo transportador das culturas indígenas, de sua condição passada de plenitude até o momento atual, [...] ocasião em que muitas vezes já estão despojadas de sua unidade e sistematicidade" (1999a, p. 124). Nessa abordagem, os indígenas são vistos como "sujeitos históricos plenos" fora dos estágios evolutivos da humanidade. Seguindo esse ponto de vista, os indígenas passam a ser situados na contemporaneidade e em um tempo histórico múltiplo e diferenciado.

Durante o processo de colonização, as elites europeias eram cúmplices da promoção de um sistema alternativo de convivência indígena e também da reelaboração cultural dos agentes sociais locais, o que refletia uma "adaptação resistente" (STERN, 1987). Isto explica o fato de várias etnias indígenas dos Andes e das terras baixas serem reconhecidas enquanto camponesas e não como indígenas. Com o processo de transformação do indígena em camponês por meio de uma "adaptação resistente" (STERN, 1987), percebi que existe um conjunto de imposições dos espanhóis e criollos, porém um desempenho ativo dos indígenas no sentido de forjar "espaços próprios" nos limites daqueles padrões de convivência.

Segundo Garrett (2005), no fim do século XIX, o avanço do Estado boliviano confrontava os postulados da civilização (na época, progresso; hoje em dia, desenvolvimento), por um lado, e por outro, o "atraso" dos povos indígenas. Uma das formas de consolidação do Estado se deu por meio da expansão das fronteiras: expedições exploratórias e tentativas de colonização. A fronteira guarani, "o que correspondia a linha divisória entre a 'civilização' e 'barbárie' desde a época dos incas até o final do século XIX” 
(GARRET, 2005, p. 3, tradução minha), foi palco de confrontos entre os guaranis e os karai (brancos) por conta do controle do território.

No decorrer da história dos guaranis, as modificações em sua base territorial foram acompanhadas de mudanças sociais e de uma ressignificação de suas manifestações simbólicas. Assim, a concepção de territorialização definida por Oliveira Filho (1999b) categoria amplamente utilizada nos estudos sobre os povos indígenas no Nordeste brasileiro possibilita compreender o processo de reorganização social que implica, dentre outros fatores, "numa reelaboração da cultura e da relação com o passado" (OLIVEIRA FILHO, 1999b, p. 22) dos guaranis na Bolívia a partir do evento de Kuruyuki.

Albert (2002), acerca do movimento indígena, afirma que o discurso político indígena das duas últimas décadas se estabelece em um "duplo enraizamento simbólico": em uma autoobjetivação por meio das categorias ocidentais de etnificação (território, cultura e meio ambiente) e reelaboração cosmológica dos fatos e efeitos do contato colonial. Neste caso, defendi também que os guaranis se apropriam de um fato histórico para legitimar a constituição de uma organização indígena, a APG.

Segundo Bourdieu (1989), as pessoas e os grupos sociais investem cotidianamente nas lutas de classificação e nomeação, tudo o que define a ideia que eles têm de si próprios, tudo pelo qual eles se constituem como nós por oposição a eles. Isso explica a força mobilizadora no tocante à cultura nacional guarani.

Para Bourdieu (1989), o poder simbólico só é exercido quando reconhecido. Assim, à medida que os guaranis assumiram sua identidade étnica nacional e suas reivindicações, começaram a destruição do poder simbólico imposto pelo Estado uni-nacional colonial, como uma estratégia de sobrevivência por meio da busca constante de sua revitalização política e cultural, até o fim da década de 1980, "adormecida" entre os guaranis.

A revolução simbólica contra a dominação simbólica e os efeitos de intimidação que ela exerce tem em jogo não, como se diz, a conquista ou a reconquista de uma identidade, mas a reapropriação coletiva deste poder sobre os princípios de construção e de avaliação da sua própria identidade de que o dominado abdica em proveito do dominante enquanto aceita ser negado e negar-se (e negar os que, entre os seus, não querem ou não podem negar-se) para se fazer reconhecer (BOURDIEU, 1989, p. 125). 
A partir dessa ideia, compreende-se melhor a estratégia dos guaranis de negociar a representação de sua organização indígena, não em seus próprios termos, mas nos termos do dominante (Estado) e, por conseguinte, da história escrita pelos não indígenas, porém reinterpretada a seu favor.

O discurso de vítima no massacre de Kuruyuki também pode ser interpretado como uma estratégia de reapropriação da visão dominante sobre o grupo, visando à constituição de sua cultura nacional. Isto é, os guaranis se apropriaram do fato de terem sidos derrotados no massacre para marcar, por meio disso, a permanência de sua distintividade.

\subsection{Considerações finais}

Esta dissertação discutiu o processo de construção da nação guarani a partir da situação social específica promovida com a comemoração do massacre do Kuruyuki, evento gerenciado pela Asamblea del Pueblo Guaraní (APG). Com a pesquisa, conclui que essa organização indígena articula ideologicamente o discurso de nação guarani, reconstruindo uma identificação coletiva que permite maior presença diante do Estado e das agências internacionais.

O processo de construção da nação guarani não aparenta querer conquistar o poder do Estado, mas sim construir um poder local autonômico e desenvolver uma consciência política de filiação étnica a fim de constituir uma unidade guarani. A tomada de consciência, em termos nacionais, não se refere a uma estatização, como salientei, mas sim à fundação de entidades territoriais autônomas de acordo com normas e procedimentos próprios. Inclusive, a APG surgiu com o objetivo de reconstituição territorial. A partir da recente constitucionalização da autonomia indígena na Bolívia ${ }^{35}$, essa organização indígena passou a ver o discurso de autonomia indígena como opção para garantia do território guarani ancestralmente ocupado.

\footnotetext{
${ }^{35}$ A autonomia indígena originária campesina tem seu reconhecimento constitucional nos artigos número 2 e 289 da atual Constituição Política do Estado da Bolívia: "Artículo 2. Dada la existencia precolonial de las naciones y pueblos indígena originario campesinos y su dominio ancestral sobre sus territorios, se garantiza su libre determinación en el marco de la unidad del Estado, que consiste en su derecho a la autonomía, al autogobierno, a su cultura, al reconocimiento de sus instituciones y a la consolidación de sus entidades territoriales, conforme a esta Constitución y la ley". “Artículo 289. La autonomía indígena originaria campesina consiste en el autogobierno como ejercicio de la libre determinación de las naciones y los pueblos indígena originario campesinos, cuya población comparte territorio, cultura, historia, lenguas, y organización o instituciones jurídicas, políticas, sociales y económicas propias".
} 
Além disso, o trabalho sinaliza que o projeto nacional guarani é construído a partir de um ponto de vista particular ao eleger símbolos específicos para representar a nação. Por outro lado, o processo exclui aqueles que não se parecem com o modelo proposto, mostrandose parcial e interessado. Kuruyuki apresenta-se como uma instituição guarani polissêmica, manipulável e capaz de recobrir motivações muito diferentes.

A comemoração do massacre de Kuruyuki é um instrumento na constituição guarani de uma comunidade imaginada e na articulação de ações políticas autonomistas, além disso, a celebração possibilita configurar novos vínculos interinstitucionais, inter-organizacionais e político-culturais com outras organizações, bem como construir uma multiplicidade de atores e espaços culturais.

Longe de serem inermes vítimas, habitualmente assim retratados pelos livros de história escolar e pela mídia, os indígenas, sobretudo os guaranis, desenvolveram estratégias próprias que visavam não apenas à sobrevivência, mas, também, à permanente reconstrução de sua identidade e de seu modo de ser, diante das condições de destrutibilidade colonial. Kuruyuki nos permite, em uma perspectiva diacrônica, perceber os processos de reorganização cultural a partir da apropriação da memória da ruptura do grupo social, observando, sobretudo, o envolvimento dos diferentes atores guaranis na consolidação de uma agenda comemorativa de um massacre cometido pelo Estado sobre os indígenas. As memórias do fato histórico apropriado descortinam no presente diferentes significados para os atores sociais que disputam a representação dos eventos pretéritos. Nesse sentido, o tempo não é apenas físico, marcado pelo calendário. O tempo é, sobretudo, social. O desenrolar deste evidencia mudanças nas relações sociais que se decidem politicamente celebrar.

O processo em curso de afirmação nacional guarani, compreendido como a construção de uma expressão para articulação e visibilidade na esfera nacional boliviana e internacional, bem como as bases do movimento, mostram que os indígenas desempenham papel ativo diante das imposições coloniais e republicanas. Esta perspectiva defende que as relações entre indígenas e europeus são pautadas em uma interação com mudanças sociais e culturais nas duas partes. Também, desconstrói a percepção de que a colonização aniquila todos os aspectos culturais dos povos dominados, tornando-se assimilados. Nesse sentido, este trabalho exemplifica, a partir da situação social especifica da comemoração de Kuruyuki entre guaranis, que os povos indígenas também apresentam agencialidade frente à invasão europeia e neoboliviana. Eles não se comportam como entidades passivas que só recebiam as transformações impostas. Cada especificidade desse contato teve repercussões que afetaram 
intensamente a produção e reprodução simbólica e material dos indígenas. Dentre essas repercussões, este trabalho mostrou a criatividade dos guaranis em instituir a comemoração de um massacre ocorrido no fim do século XIX como produção cultural de um movimento com demandas específicas. Considerando também a importância dos agentes externos, o debate evidencia a agencialidade indígena, indicando como estes atuaram e continuam a atuar na construção da sua própria história e na projeção no futuro. Certamente, esta não é uma ideia nova nas Ciências Sociais, mas espero que eu tenha endossado o enfoque ao escrever sobre como os indígenas tomam consciência de sua etnicidade, em termos nacionais, a partir de uma experiência bélica.

Por fim, podemos considerar, a partir de Albert (2002), que as sociedades indígenas, desde que consigam sobreviver às ofensivas das forças coloniais e dos atuais Estados nacionais, não deixam de imprimir e reelaborar em suas próprias categorias culturais tudo o que é imposto a elas, até mesmo em condições de extrema violência e abusos, como é o caso do massacre de Kuruyuki, que agora é ressignificado e comemorado. 


\section{Referências bibliográficas}

ALBERT, Bruce. Introdução: cosmologias do contato no Norte-Amazônico. In: RAMOS, Alcida Rita (Orgs.). Pacificando o branco: cosmologias do contato no NorteAmazônico. São Paulo: Universidade Estadual Paulista/Imprensa Oficina do Estado, 2002.

ALBERT, Bruce. O ouro canibal e a queda do céu: uma crítica xamânica da economia política da natureza. Brasília: UnB, 1995. (Série Antropologia).

ALBÓ, Xavier. Movimientos y poder indígena en Bolivia, Perú y Ecuador. La Paz: Ed. CIPCA, 2009.

ALVAREZ, Sonia; DAGNINO, Evelina; ESCOBAR, Arturo. Introdução: o cultural e o político nos movimentos sociais latino-americanos. In: (Orgs.). Cultura e política nos movimentos sociais latino-americanos. Belo Horizonte: UFMG, 2010. p. 15-57.

ANDERSON, Benedict. Comunidades imaginadas: reflexões sobre a origem e difusão do nacionalismo. São Paulo: Companhia das Letras, 2008.

ANDRADE, Wildes. A Revolta dos Chiriguanos no Chaco Boliviano, Século XIX. In: CONGRESSO DE PESQUISA, ENSINO E EXTENSÃO - CONHECIMENTO E DESENVOLVIMENTO SUSTENTÁVEL, 7., Goiânia, 2010. Anais... Goiânia, 2010.

. A Revolta dos Chiriguanos no Chaco Boliviano. In: JORNADAS DE JOVENES INVESTIGADORES, 19., Ciudad del Este, 2011. Anais... Ciudad del Este, 2011.

Kuruyuki: a memória como batalha para construção de um movimento indígena entre os Guarani na Bolívia. In: CONGRESSO IBEROAMERICANO DE ARQUEOLOGIA, ETNOLOGIA E ETNO-HISTÓRIA, 2., Dourados, 2012. Anais... Dourados, 2012.

ASAMBlEA AUTONÓMICA GUARANí EN CHARAGUA. Proyecto de Estatuto de la Autonomía Guaraní: Charagua Iyambae. Charagua, Bolívia, 2012.

ASAMBLEA DEL PUEBLO GUARANI. Programa: En homenaje a los 120 años de la Masacre de Kuruyuki (1892-2012). Camiri, 2012.

2013.

Programa: Acto Conmemorativo de los 121 años de la Batalla de Kuruyuki. Camiri, 
BARRETTO FILHO, Henyo Trindade. Invenção ou renascimento? Gênese de uma sociedade indígena contemporânea no Nordeste. In: OLIVEIRA, João Pacheco de (Org.). A Viagem da Volta: Etnicidade, Política e Reelaboração Cultural no Nordeste Indígena. Rio de Janeiro: Contra Capa Livraria, 1999. p. 91-136.

BARTH, Fredrik. Grupos Étnicos e suas Fronteiras. In: POUTIGNAT, Philippe; STREIFFEFENART, Jocelyne. Teorias da Etnicidade. São Paulo: UNESP, 1998.

BARTOLOMÉ, Miguel Alberto. Movimientos Indios en América Latina: Los Nuevos Procesos de Construcción Nacionalitária. Brasília: UnB, 2002. (Série Antropológica, 321).

As etnogêneses: velhos atores e novos papéis no cenário cultural e político. Revista Mana, Rio de Janeiro, v. 12, n. 1, p. 39-68, 2006.

BATALLA, Guillermo Bonfil. México profundo. México: SEP, 1987.

BOURDIEU, Pierre. O poder simbólico. Rio de Janeiro: Bertrand Brasil, 1989.

BRINGEL, Breno. El estudio de los movimientos sociales en América Latina: reflexiones sobre el debate poscolonial y las nuevas geografías del activismo transnacional. In: ACOSTA, Yamandú et al. (Coords.). Pensamiento crítico y sujetos colectivos en América Latina. Montevideo, Uruguay: Núcleo-Red Pensamiento Crítico en América Latina y Sujetos Colectivos. Universidad de la República Uruguay/Ed. Trilce, 2011.

CADOGAN, Leon. Ayvu rapyta. Textos míticos de los Mbya-Guaraní del Guairá. Asunción: Ceaduc/Cepag. Biblioteca Paraguaya de Antropología. Vol. XVI, Fundación Leon Cadogan, 1992.

CARDOSO DE OLIVEIRA, Roberto. O trabalho do Antropólogo. São Paulo: Editora UNESP, 2000.

CAUREY, Elías. Nación Guaraní. Ñamae Ñande Rekore: una mirada a nuestro modo de ser. Território Guarani, Bolívia, 2012.

CLASTRES, Hélène. Terra sem Mal: o Profetismo Tupi-Guarani. São Paulo: Brasiliense, 1978.

CLATRES, Pierre. A Sociedade contra o Estado. São Paulo: Cosac \& Naify, 2003. 
COMBÈS, Isabelle. Las Batallas de Kuruyuiki: Variciones sobre una derrota chiriguana. Bulletin de l'Institut Français d'Études Andines, 34 (2), 2005a.

Etno-historias del Isoso: Chane y chiriguanos en el Chaco Boliviano (Siglos XVI a XX). La Paz: Fundación PIEB: IFEA, 2005b.

Nominales pero atrevidos: capitanes chiriguanos aliados en el Chaco boliviano, siglo XIX. Bulletin de l'Institut Français d'Études Andines, 2005c.

; VILLAR, Diego. Os mestiços mais puros. Representações chiriguano e chané da mestiçagem. Revista Mana, Rio de Janeiro, v. 13, n. 1, 2007.

DURKHEIM, Émile. As Formas Elementares da Vida Religiosa. São Paulo: Martins Fontes, 2003.

EL PAÍS. Los guaraníes proponen la paz al Rey de España. El País, edición impresa, 28 de enero de 1999.

GARRET, Ana María Lema. A peripheral country: north-south internal conflicts in Bolivia. Tradução de Julio H. Cole. Revista de Humanidades y Ciencias Sociales, Santa Cruz de la Sierra, v. 1, 2005.

GLUCKAMN, Max. Análise de uma situação social na Zululândia moderna. In: FELDMANBIANCO, Bela (Org.). Antropologia das sociedades contemporâneas. São Paulo: Global Universitária, 1987.

GUSTAFSON, Bret. New Languages of the State: Indigenous Resurgence and the Politics of Knowledge in Bolivia. Durham: Duke University Press, 2009.

HALBWACHS, Maurice. A Memória Coletiva. São Paulo: Ed. Centauro, 1994.

HALL, Stuart. A identidade cultural na pós-modernidade. 7. ed. Rio de Janeiro: DP\&A, 2003.

HOBSBAWN, Eric. Introdução: a invenção das tradições. In: ; RANGER, Terence (Org.). A invenção das tradições. 2. ed. Rio de Janeiro: Paz e Terra, 1997. p. 9-24.

; RANGER, Terence (Org.). A invenção das tradições. 2. ed. Rio de Janeiro: Paz e Terra, 1997. 
INTER-AMERICAN COMMISSION ON HUMAN RIGHTS (IACHR). Comunidades Cautivas: Situación del Pueblo Indígena Guaraní y Formas Contemporáneas de Esclavitud em el Chavo de Bolivia, 24 December 2009, OEA/Ser.L/V/II. Doc. 58. Disponível em: <http://www.refworld.org/docid/4bd967a72.html>. Acesso em: 28 maio 2013.

INSTITUTO NACIONAL DE ESTADÍSTICA DE BOLIVIA (INE). Censo Nacional Población y Vivienda 2001. La Paz, 2001. Censo Nacional Población y Vivienda 2012. La Paz, 2012.

LINERA, Álvaro García. A potência plebéia: ação coletiva e identidades indígenas, operárias e populares na Bolívia. Tradução de Mouzar Benedito e Igor Ojeda. São Paulo: Boitempo; Buenos Aires: CLACSO, 2010.

LORENZONI, Patricia; FOLLÉR, Maj-Lis. Introduction, Anales. Nueva Época, University of Gothenburg, n. 13, p. 5-8, 2011.

MAUSS, Marcel. Ensaio sobre a dádiva. In: . Sociologia e Antropologia. São Paulo: Cosac Naif, 2003.

MELIÁ, Bartomeu. El Paraguay Inventado. CEPAG, Asunción, 1997. Los Guarani-Chiriguano: Nande Rekó, nuestro modo de ser. La Paz, Cipca, 1988.

MÉTRAUX, Alfred. El origen del sol y la luna según la mitología chiriguana. Physis. Revista de la sociedad Argentina de Ciencias Naturales, Buenos Aires, n. 10, p. 187-192, 1939.

MINISTERIO DE LA PRESIDENCIA DE BOLIVIA. Hacia la erradicación de la servidumbre y el trabajo forzoso en el Chaco y la Amazonía boliviana. La Paz: Estado Plurinacional de Bolivia. 2010.

MORÓN, Mauro Hurtado. Ser Ser libre no es fácil, pero vale la pena: reasentamientos de familias guaranies en el Chaco chuquisaqueño, 1993-1997. La Paz: CIPCA. 2008.

NORA, Pierre. Entre história e memória: a problemática dos lugares. Revista Projeto História, São Paulo, v. 10, p. 7-28, 1993.

OLIVEIRA FILHO, João Pacheco de. Ensaios em Antropologia Histórica. Rio de Janeiro: Editora UFRJ, 1999a. 
. Uma Etnologia dos "Índios Misturados": Situação Colonial, Territorialização e Fluxos Culturais. In: OLIVEIRA, João Pacheco de (Org.). A Viagem da Volta: Etnicidade, Política e Reelaboração Cultural no Nordeste Indígena. Rio de Janeiro: Editora ContraCapa, 1999b.

ORTIZ, García Elio; CAUREY, Elías. Diccionario etimológico y etnográfico de la lengua guaraní hablada en Bolivia (guaraní-español). SENAPI, La Paz, 2011.

PEIXOTO, Rodrigo. Indígenas resistentes se movimentam por identidade e território no Baixo Tapajós. CONFERÊNCIA DA SALSA, 7., Belém, 2011. No prelo 2011.

PIFARRE, Francisco. Guaranís: el derecho a ser pueblo. Cuarto Intermedio, n. 23. p. 3-19, 1992.

PINCKERT JUSTINIANO, Guillermo. La guerra chiriguana. Santa Cruz de la Sierra, 1978. POLLAK, Michael. Memória, Esquecimento, Silêncio. Estudos Históricos, Rio de Janeiro, v. 2, n. 3, 1989.

RAMOS, Alcida Rita. Nações dentro nação: um desencontro de ideologias. Brasília: UnB, 1993. (Série Antropologia, 147).

RANGER, Terence. A Invenção da Tradição na África Colonial. In: ; HOBSBAWM, Eric (Org.). A invenção das tradições. 2. ed. Rio de Janeiro: Paz e Terra, 1997. p. 219-270.

SAHLINS, Marshall. Ilhas de História. Rio de Janeiro: Zahar, 1987.

. Cosmologias do capitalismo: o setor transpacífico do 'sistema mundial'. In: Cultura na Prática. Rio de Janeiro: Editora da UFRJ, 2007.

SAIGNES, Thierry. La guerra 'salvaje' en los confines de los Andes y del Chaco: La resistencia chiriguana a la colonización europea. Quinto Centenario, v. 8, 1984.

Ava y Karai. Ensayos sobre la historia chiriguano (siglos XVI-XX). La Paz: HISBOL, 1990.

SANABRIA FERNÁNDEZ, Hernando. Apiaguaiqui-Tumpa. Biografía del pueblo chiriguano y de su último caudillo. La Paz/Cochabamba: Los Amigos del Libro, 1972. 
SILVA, Cristhian Teófilo da. Unrecognized Indians and the Politics of Nonrecognition in Brazil. Anales Nueva Época, v. 13, p. 183-206, 2010.

SILVA, Kelly Cristiane da. A nação cordial: uma análise dos rituais e das ideologias oficiais de "comemoração dos 500 anos do Brasil". Rev. bras. Ci. Soc., v. 18, n. 51, p. 141-160, fev. 2003.

SMITH, Anthony. The Ethnic Origins of Nations. Oxford: Blackwell Publishers, 1986.

STERN, Steve J. Resistance, rebellion and consciousness in the Andean peasant world, 18th to 20th centuries. Madison: The University of Wisconsin Press, 1987.

SUSNIK, Branislava. Chiriguanos I. Dimensiones etnosociales. Asunción: Museo etnográfico Andrés Barbero, 1968.

SVAMPA, M.; STEFANONI, P.; FORNILlO, B. Debatir Bolivia. Los contornos de un proyecto de descolonización. Buenos Aires: Taurus. 2010.

TARROW, Sidney. O poder em movimento. Movimentos sociais e confronto político. Petrópolis, Rio de Janeiro: Ed. Vozes, 2009.

TURNER, Victor (Ed.). Celebration: Studies in festivity and ritual. Washington/DC, Smithsonian Institution Press, 1982.

VAN VELSEN, J. A análise situacional e o método de estudo de caso detalhado (1967). In: FELDMAN-BIANCO, Bela (Org.). Antropologia das sociedades contemporâneas. São Paulo: Global Universitária, 1987.

WARREN, Kay. Os movimentos indígenas como um desafio ao paradigma do movimento social unificado na Guatemala. In: ALVAREZ, Sonia; DAGNINO, Evelina; ESCOBAR, Arturo (Orgs.). Cultura e política nos movimentos sociais latino-americanos. Belo Horizonte: UFMG, 2010. p. 257-299.

WOLF, Eric. Nação, nacionalismo e etnicidade. In: RIBEIRO, Gustavo Lins; FELDMANBIANCO, Bela (Orgs.). Antropologia e Poder: contribuições de Eric Wolf. Brasília: UnB, São Paulo: Imprensa Oficial do Estado, Editora UNICAMP, 2003. 


\section{ANEXOS}

Figura 1. Fragmento do mapa da Bolívia com destaque para o Departamento de Santa Cruz (cidade de Santa Cruz de la Sierra e Camiri) e Chuquisaca (Kuruyuki e Ivo)

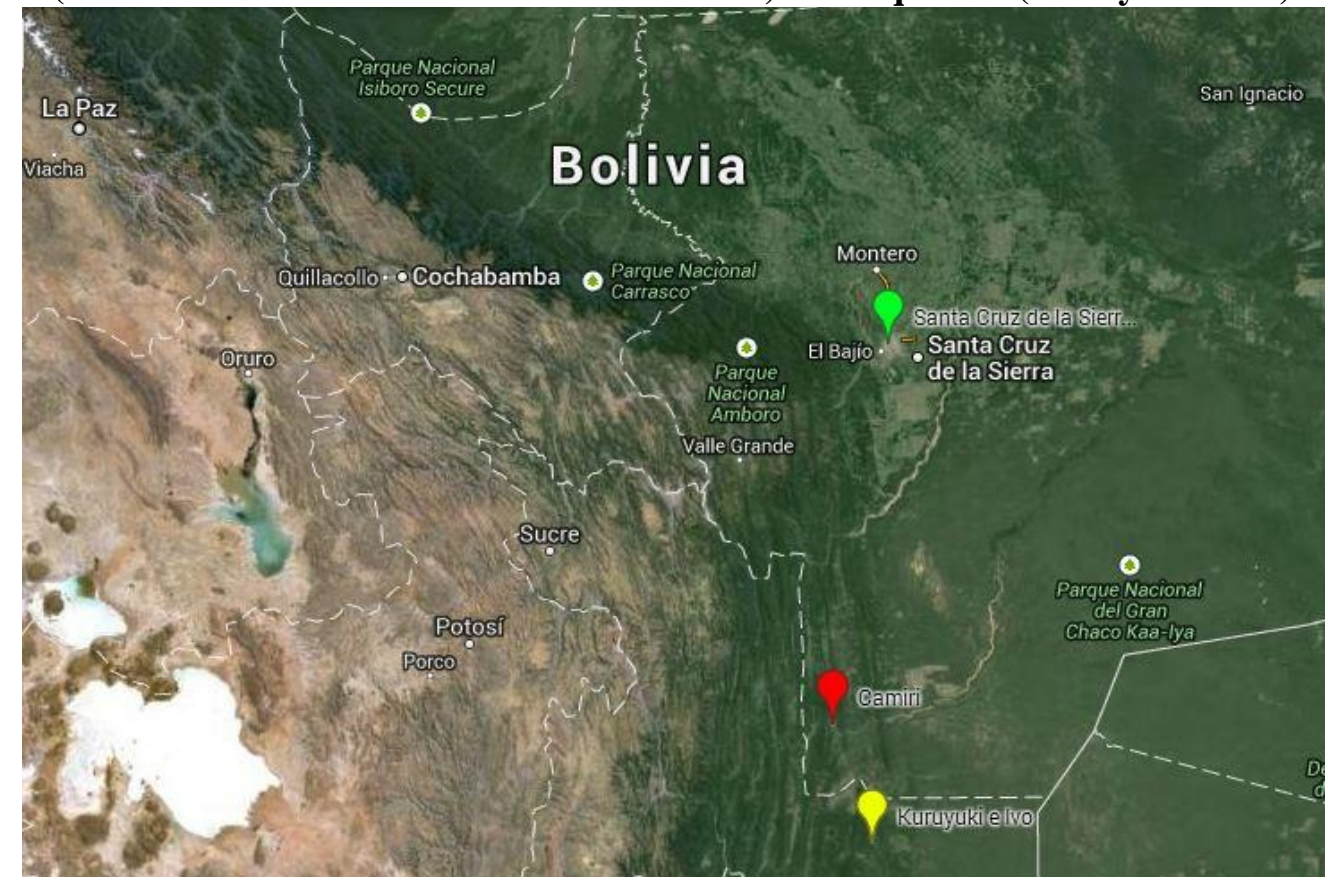

Fonte: Google Maps. Crédito: Wildes Andrade.

Figura 2. Fragmento do mapa do Departamento Chuquisaca, em destaque a Ruta 9 , Comunidade de Kuruyuki e Ivo e as trincheiras

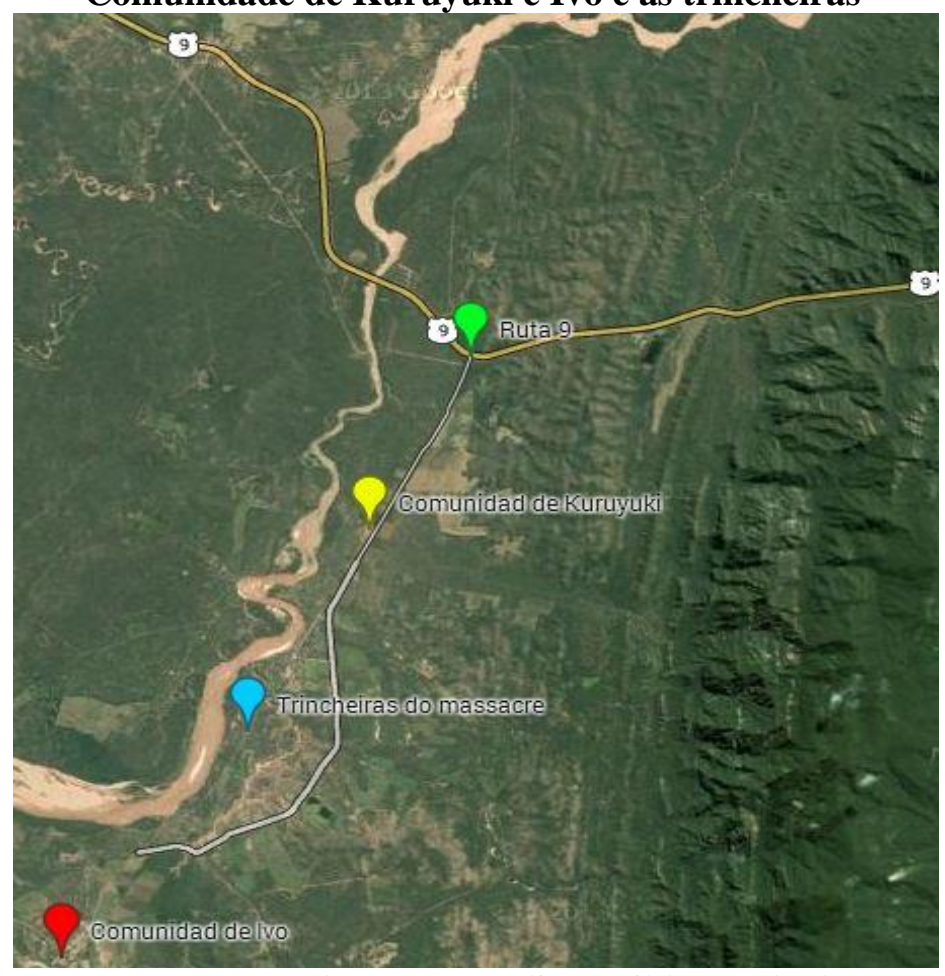

Fonte: Google Maps. Crédito: Wildes Andrade. 
Figura 3. Fragmento do mapa da Comunidade de Ivo, Departamento Chuquisaca, em destaque a escola indígena, o posto de saúde, o palanque, a igreja, o cemitério e a Unibol

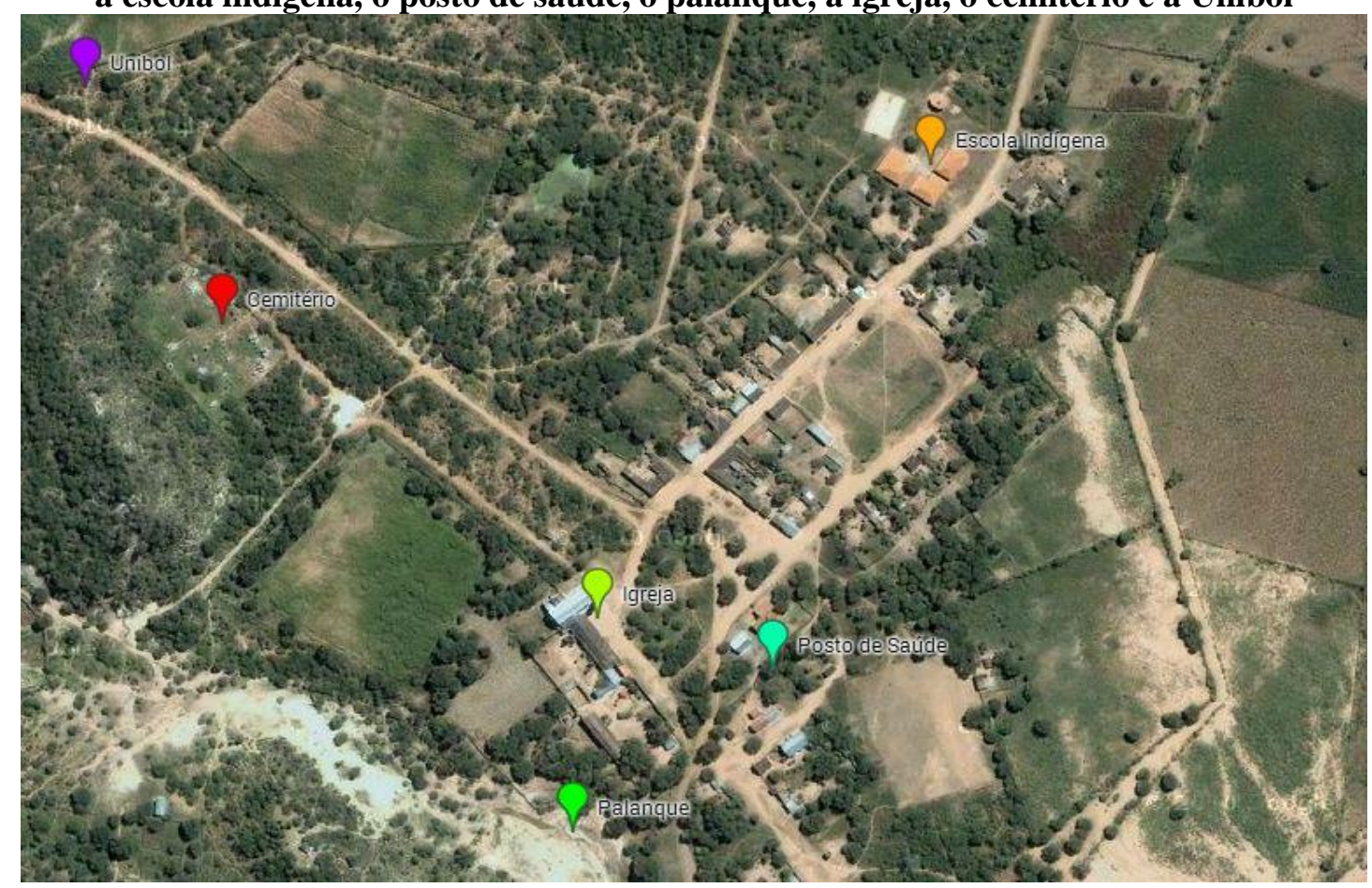

Fonte: Google Maps. Crédito: Wildes Andrade.

Figura 4. Panorama da cidade de Camiri

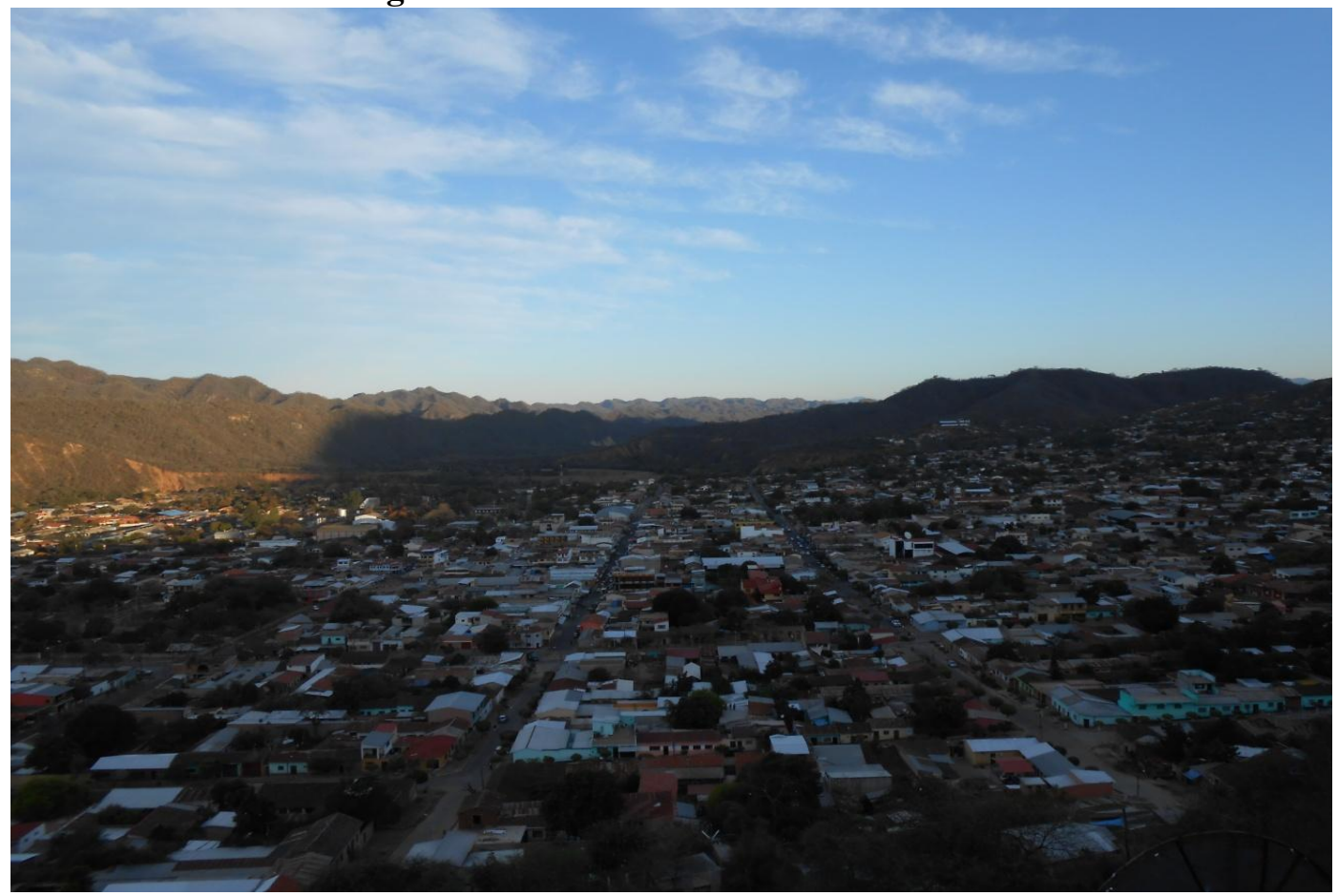

Fonte: Wildes Andrade. 
Figura 5. Entrada da APG Nacional em Camiri

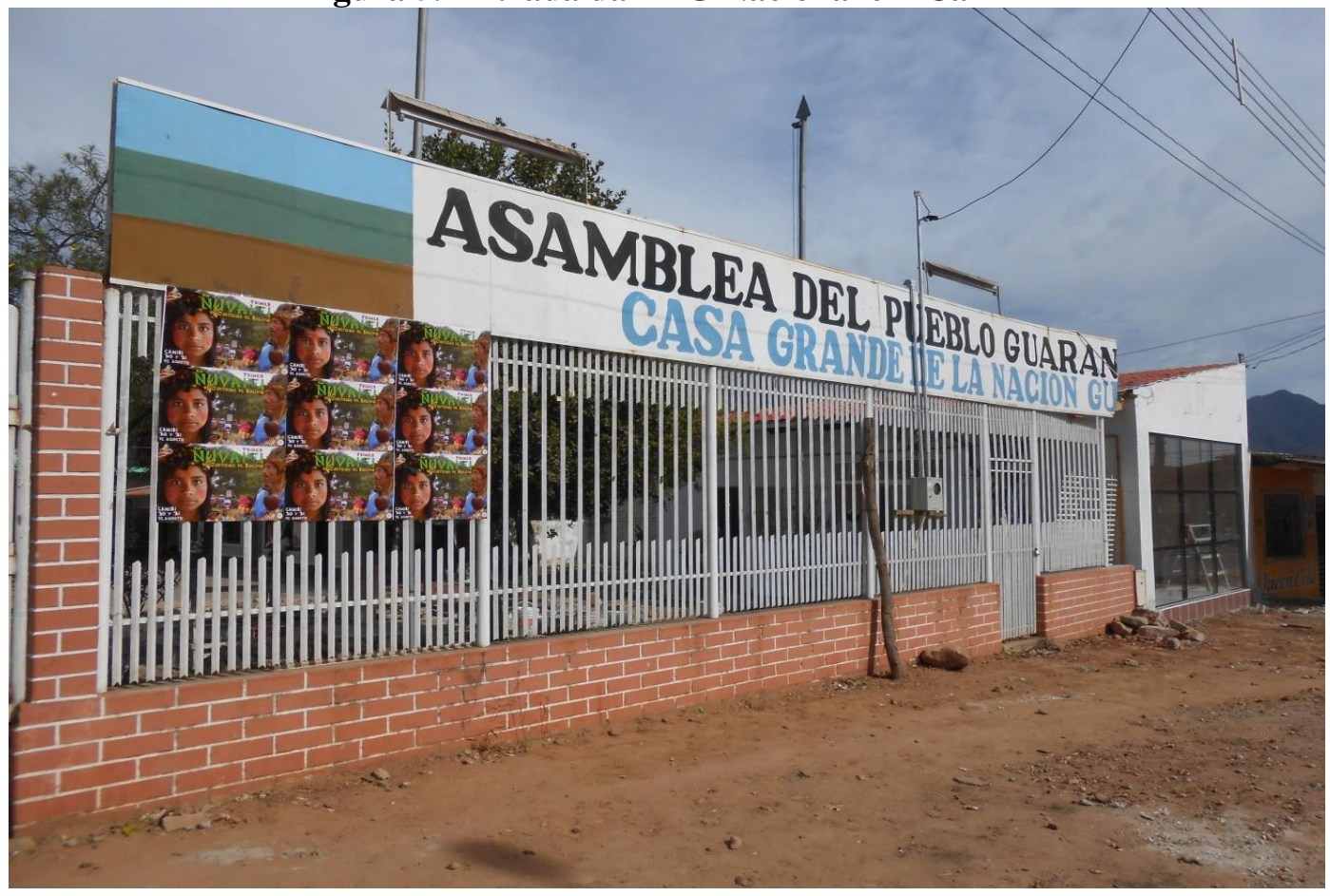

Fonte: Wildes Andrade.

Figura 6. Concentração em frente à Catedral de Camiri para comemoração de Kuruyuki, em

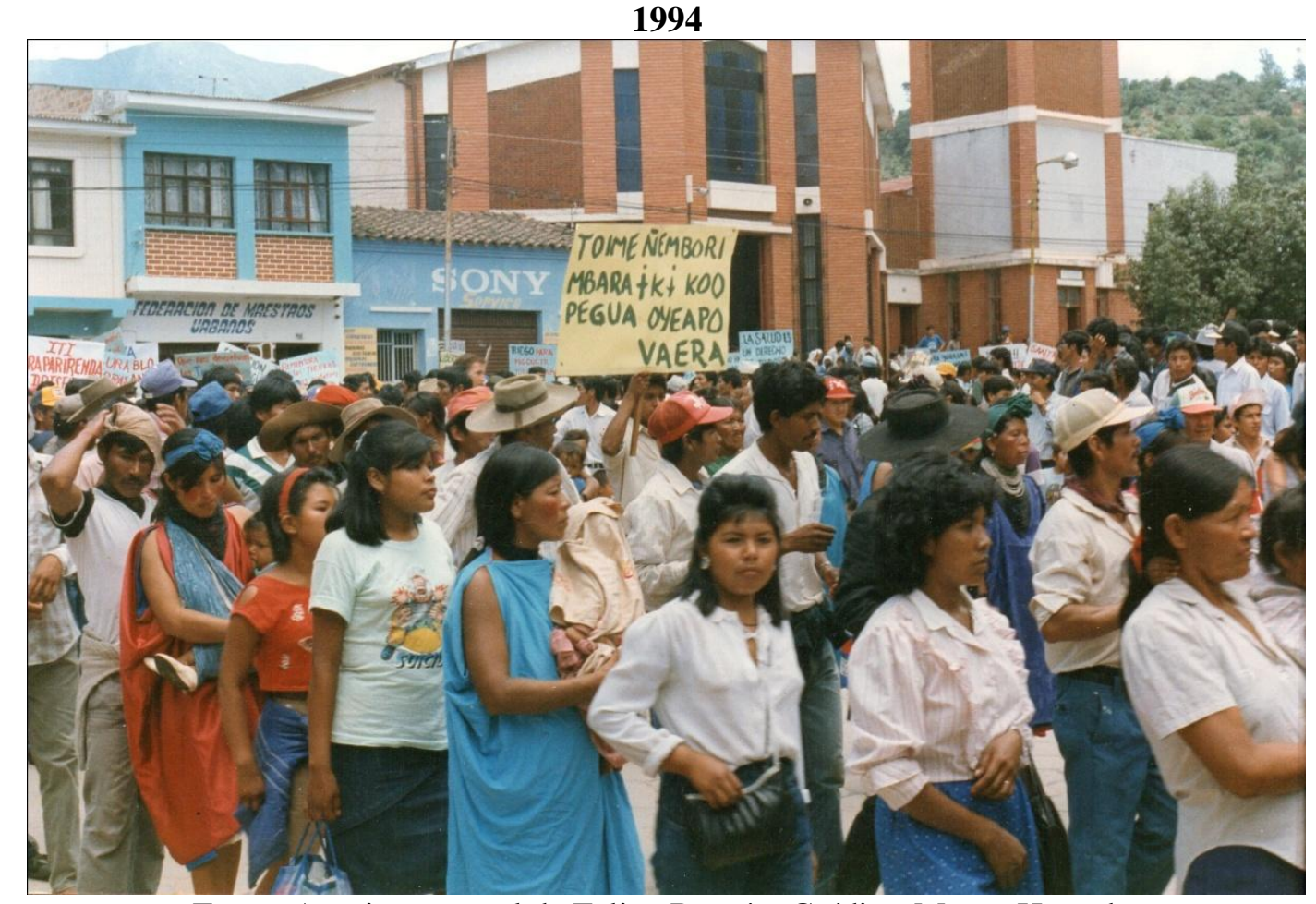

Fonte: Arquivo pessoal de Felipe Román. Crédito: Mauro Hurtado. 
Figura 7. Marcha guarani saindo de Camiri em direção à Kuruyuki, em 1992

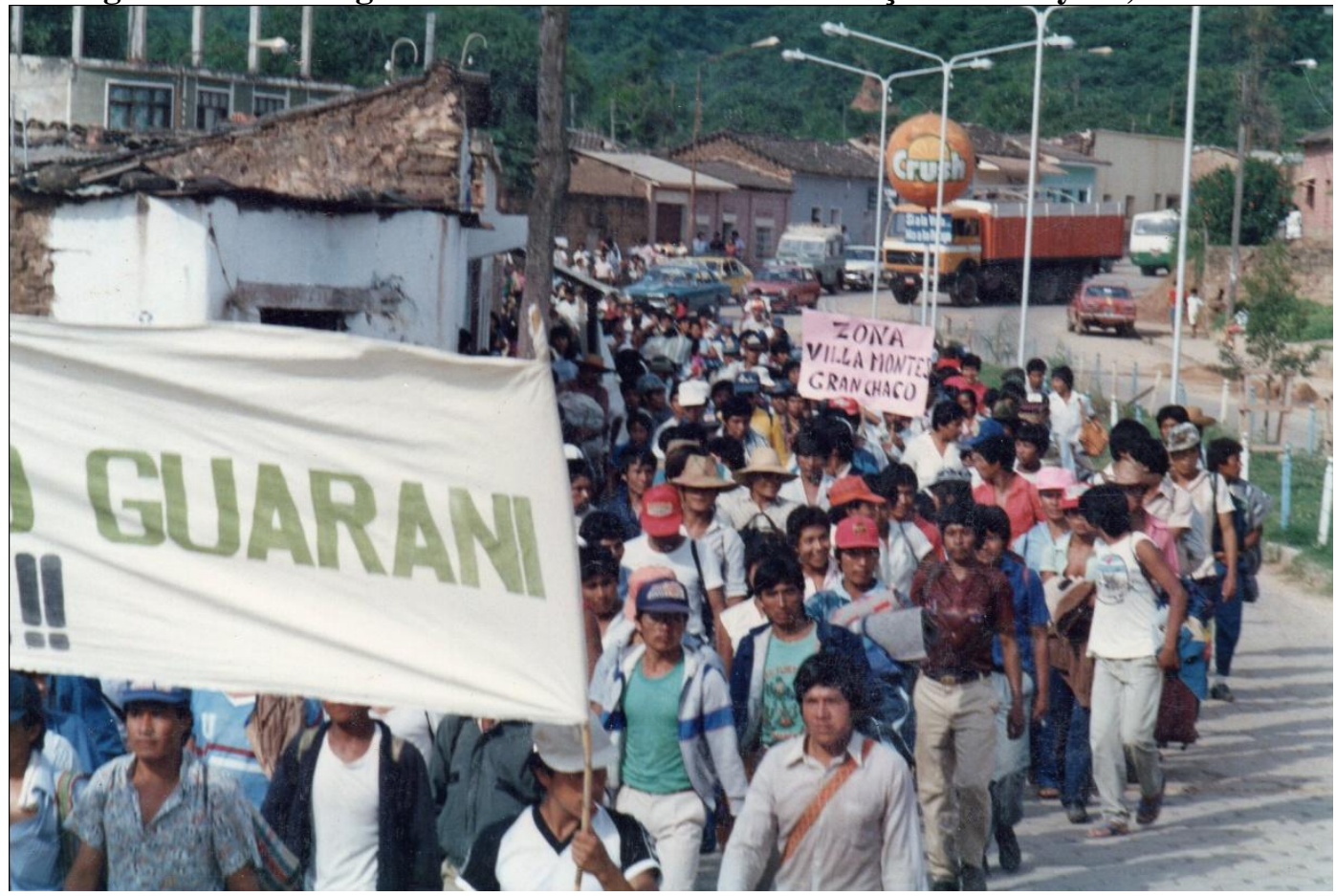

Fonte: Arquivo pessoal de Felipe Román. Crédito: Mauro Hurtado.

Figura 8. Marcha guarani próximo a Salinas, depois de uma chuva, em direção à Kuruyuki, em 1992

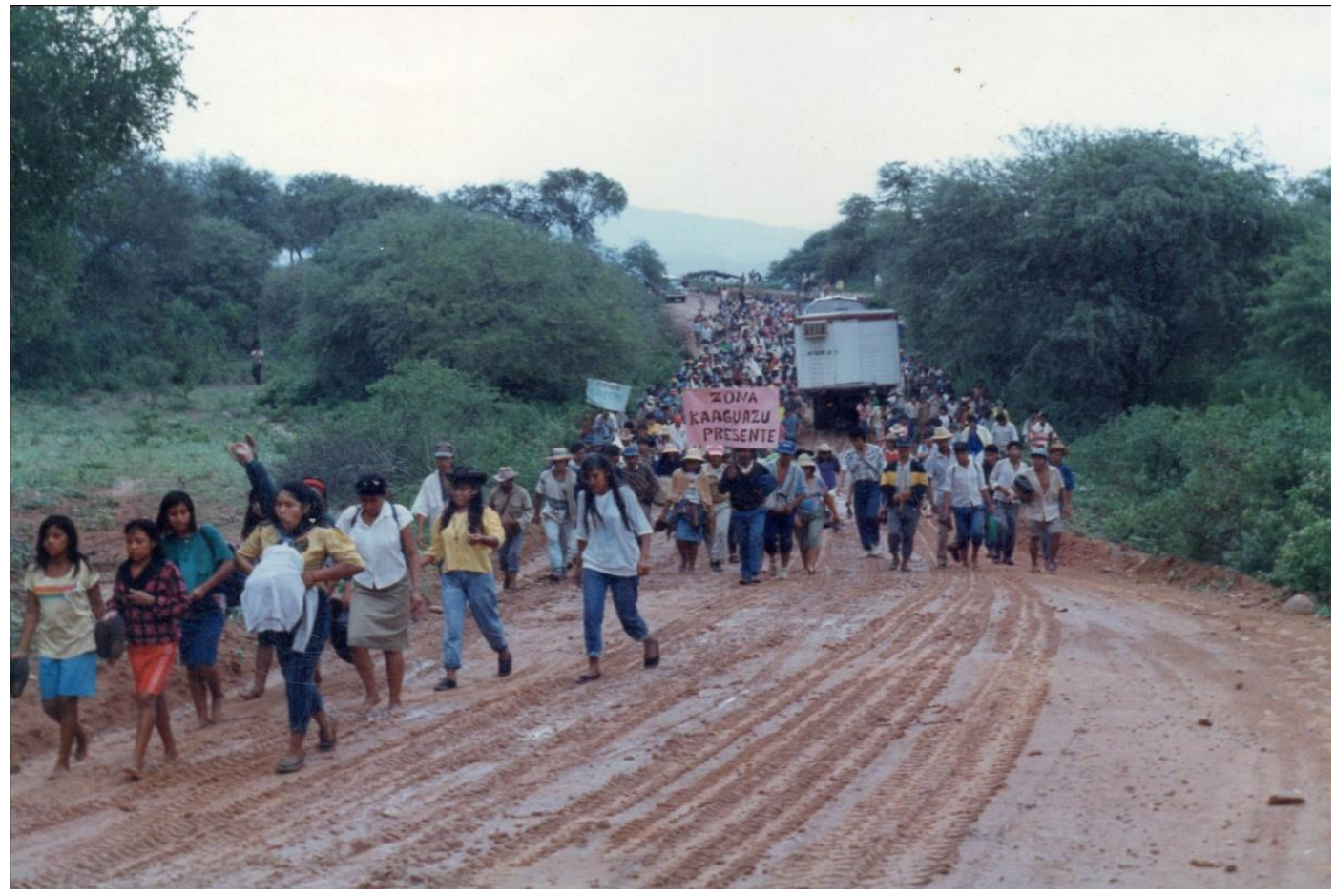

Fonte: Arquivo pessoal de Felipe Román. Crédito: Mauro Hurtado. 
Figura 9. Missa em frente à Iglesia San Buenaventura em homenagem aos mortos em Kuruyuki, 1992

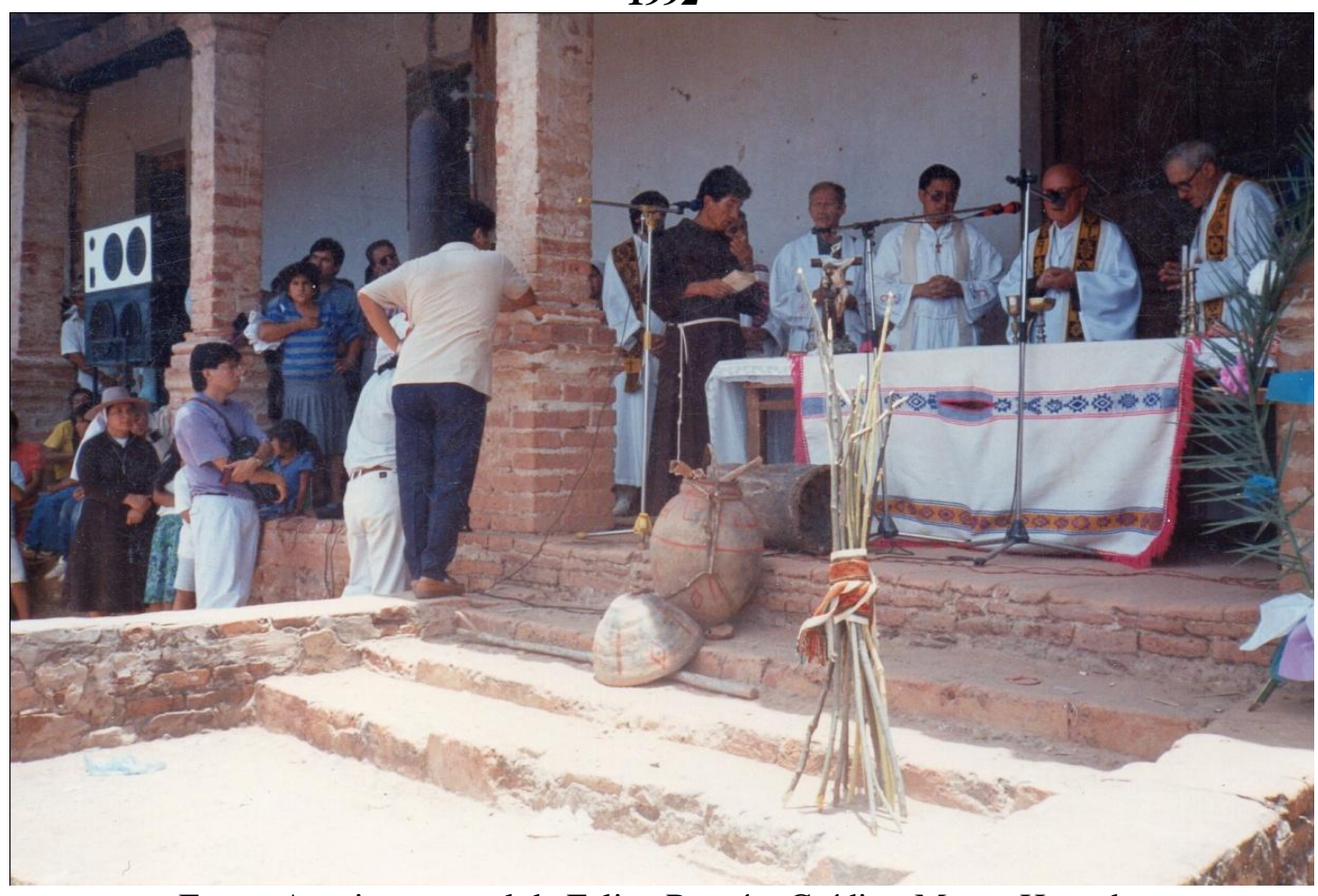

Fonte: Arquivo pessoal de Felipe Román. Crédito: Mauro Hurtado.

Figura 10. Marcha a Kuruyuki, próximo à localidade de Cuevo, 1992.

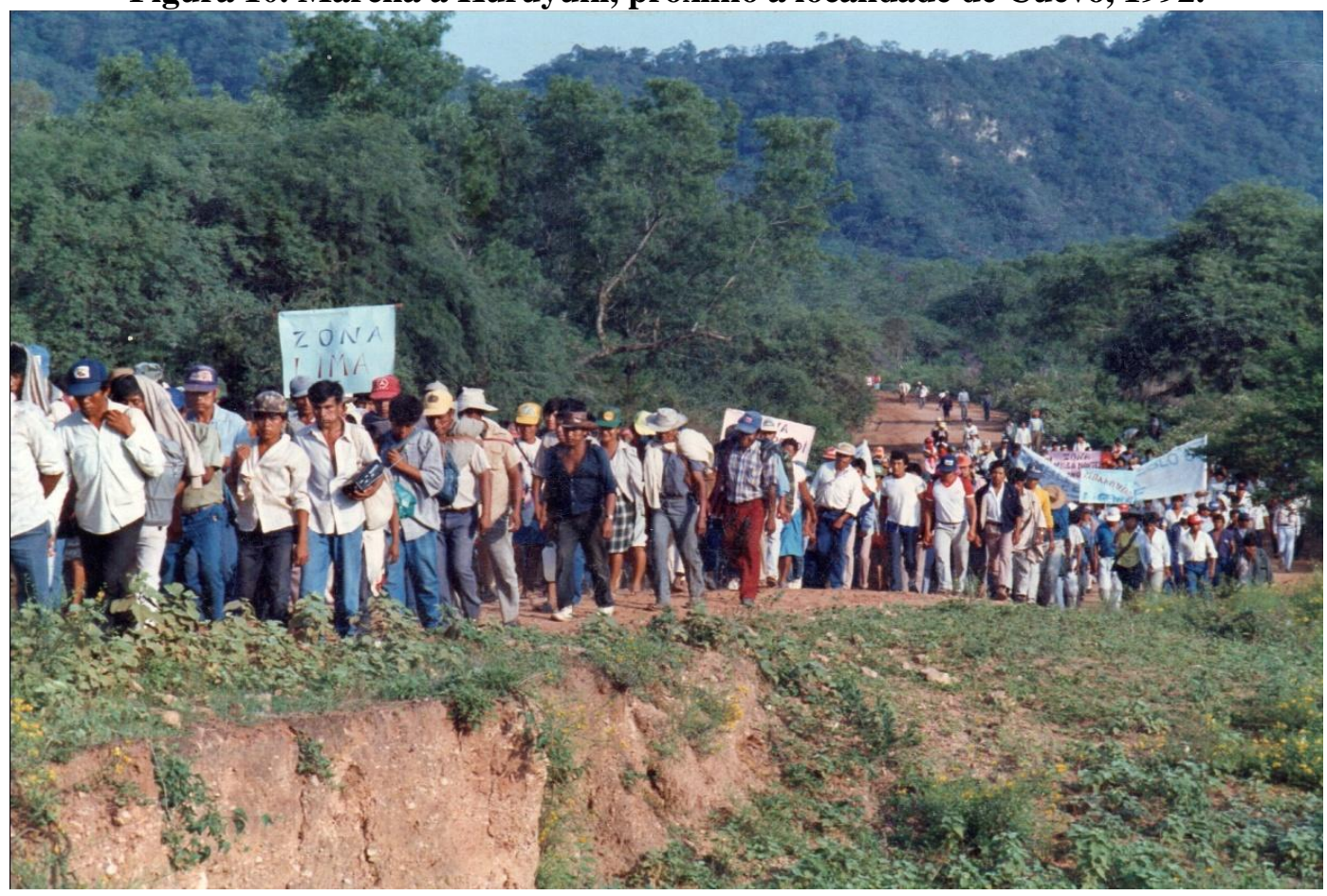

Fonte: Arquivo pessoal de Felipe Román. Crédito: Mauro Hurtado. 
Figura 11. Marcha em direção à Kuruyuki, 1992

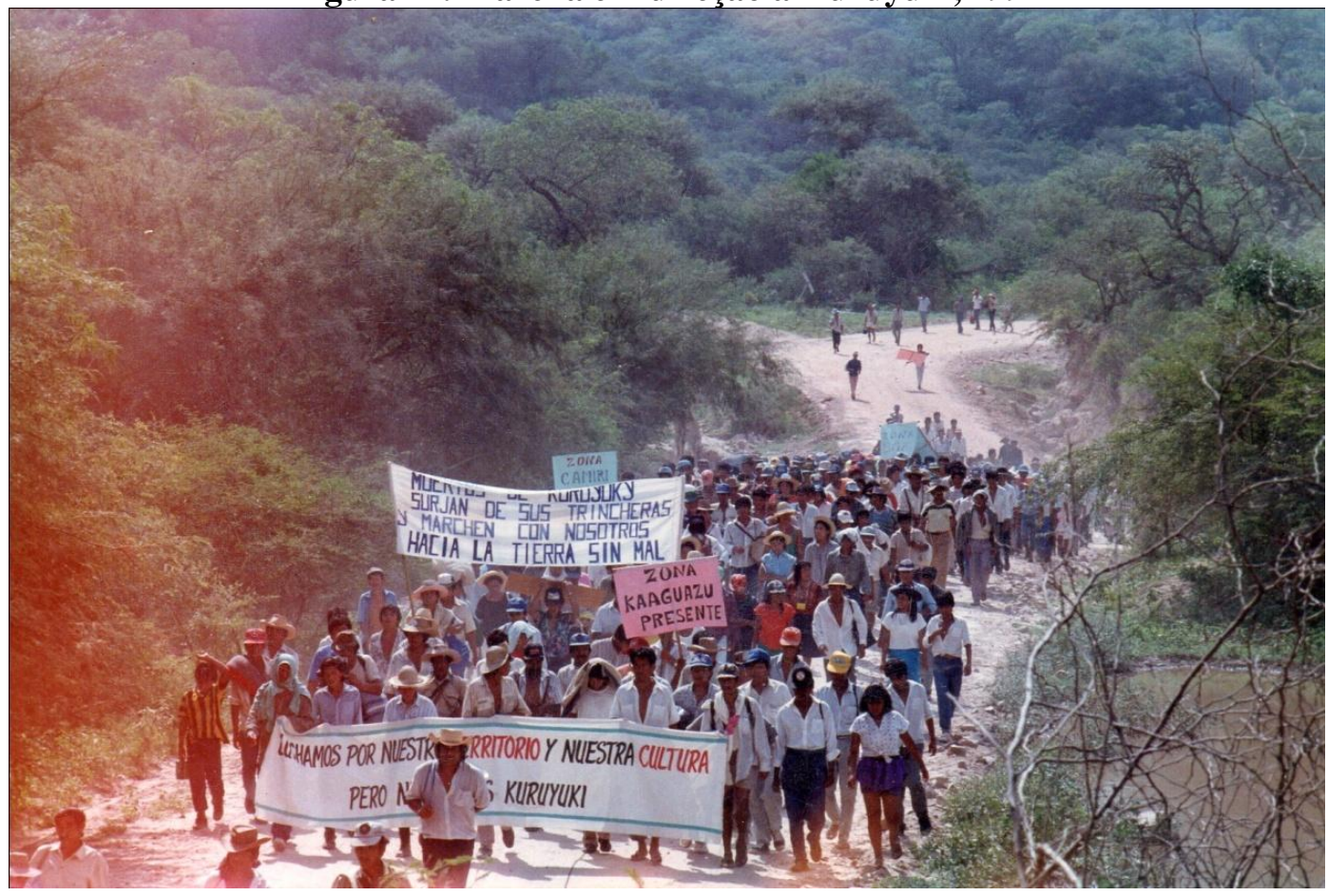

Fonte: Arquivo pessoal de Felipe Román. Crédito: Mauro Hurtado.

Figura 12. Autoridades do Estado e lideranças guaranis na primeira comemoração, 1992

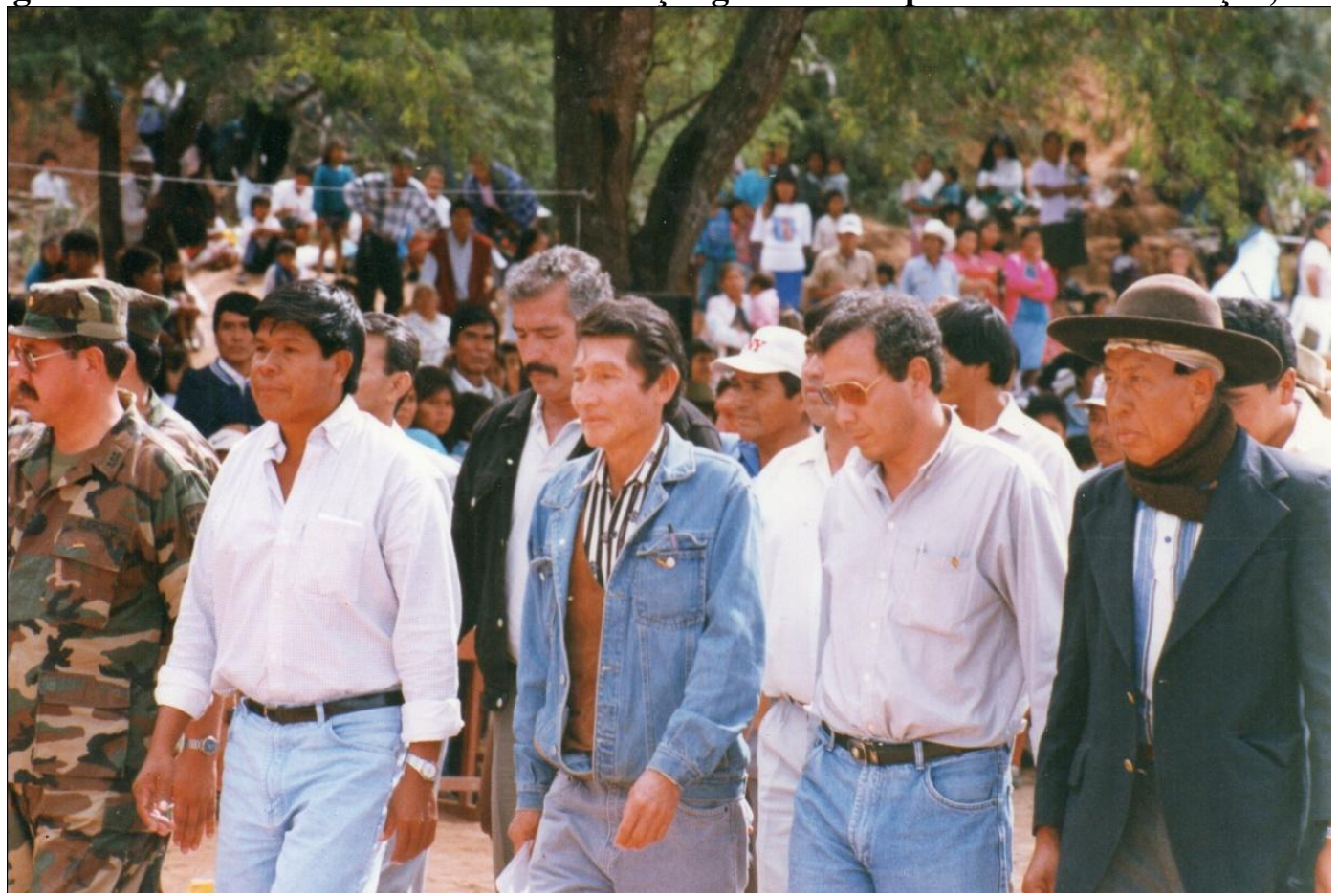

Fonte: Arquivo pessoal de Felipe Román. Crédito: Mauro Hurtado. 
Figura 13. Cruz em homenagem aos mortos no massacre, Comunidade de Ivo, 1992

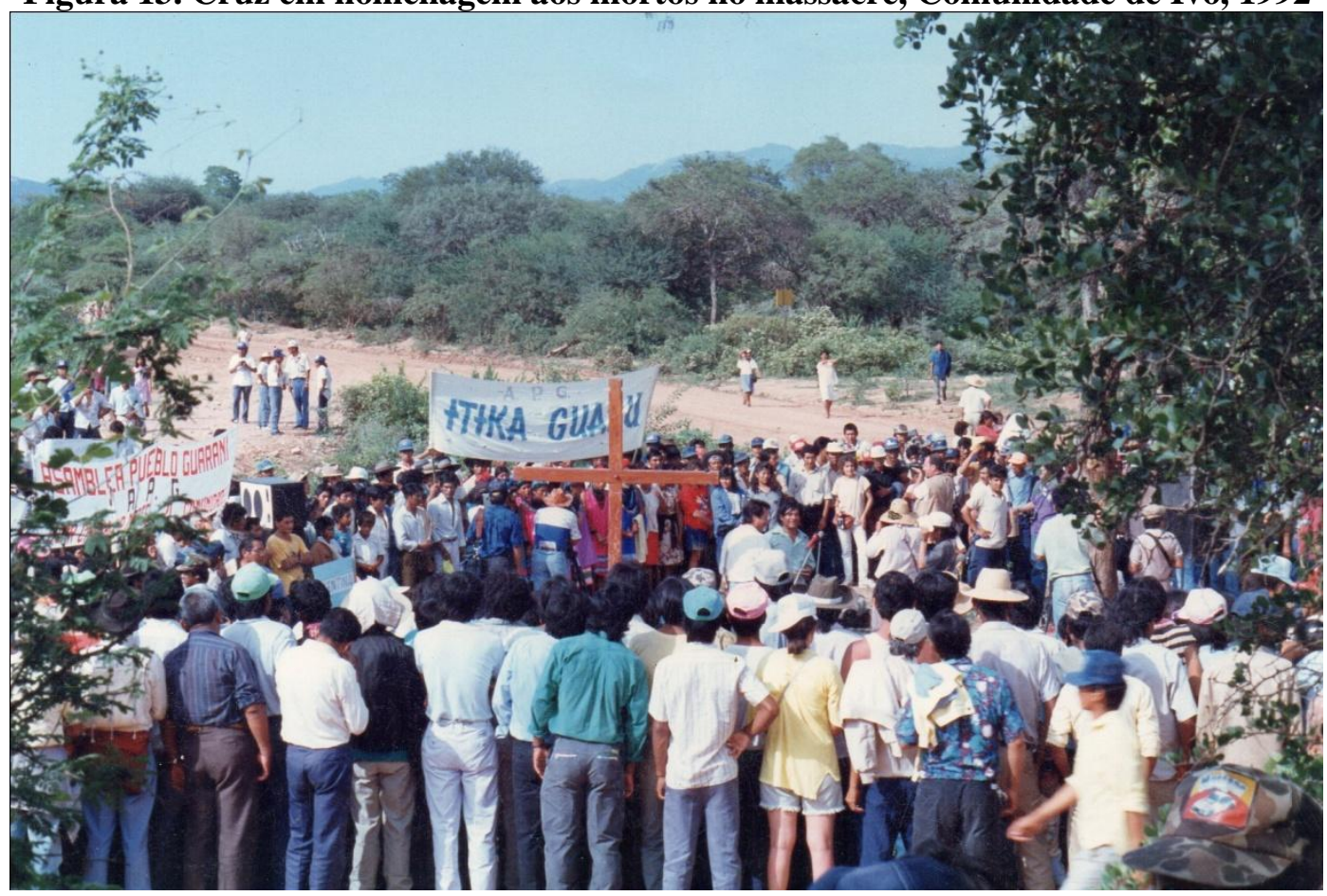

Fonte: Arquivo pessoal de Felipe Román. Crédito: Mauro Hurtado.

Figura 14. Comemoração da morte de Apiaguaiqui Tumpa, 29 de março de 1992, Monteagudo

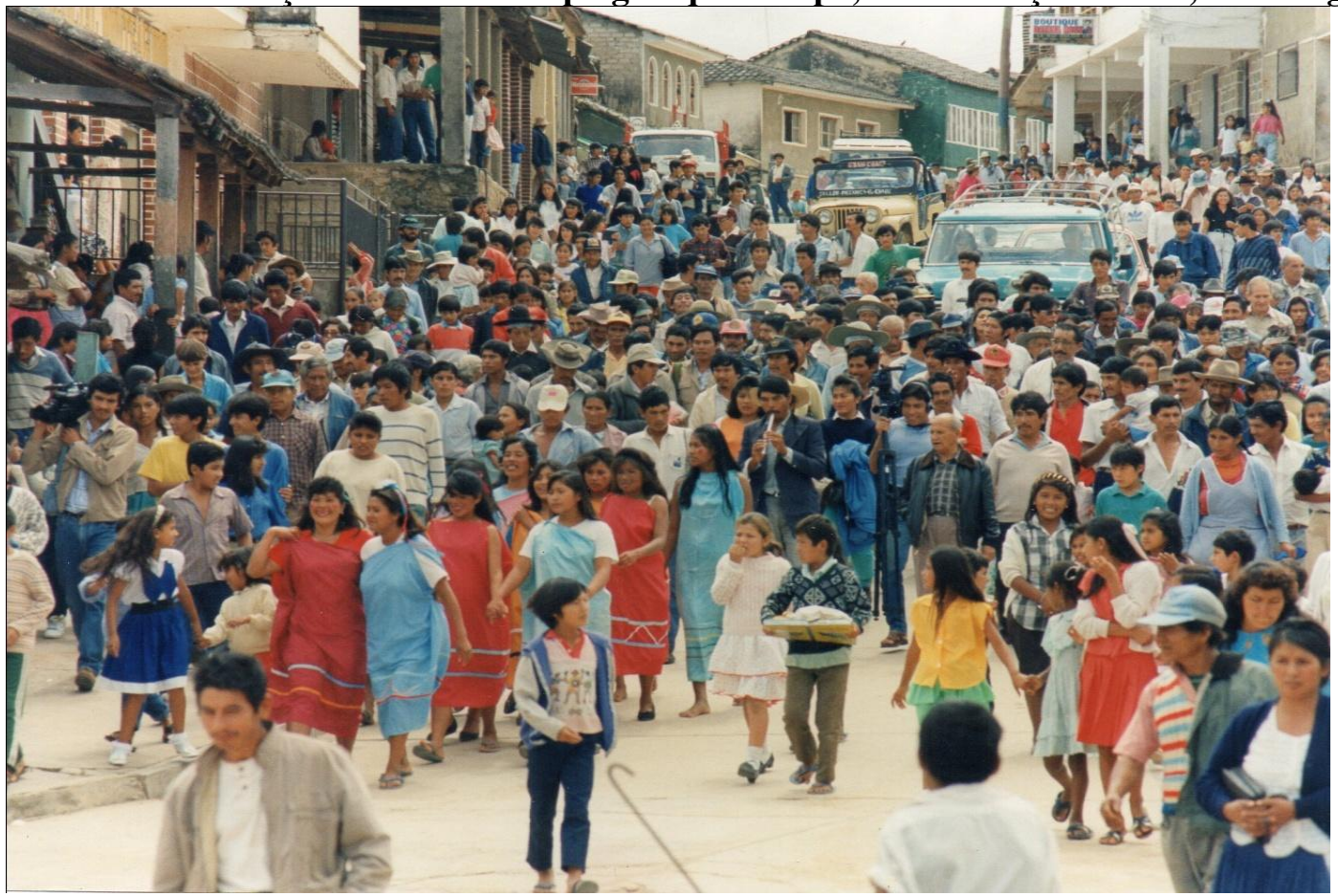

Fonte: Arquivo pessoal de Felipe Román. Crédito: Mauro Hurtado. 
Figura 15. Sepultamento dos restos mortais dos guerreiros de Kuruyuki no ossuário do cemitério da comunidade de Ivo, 1992

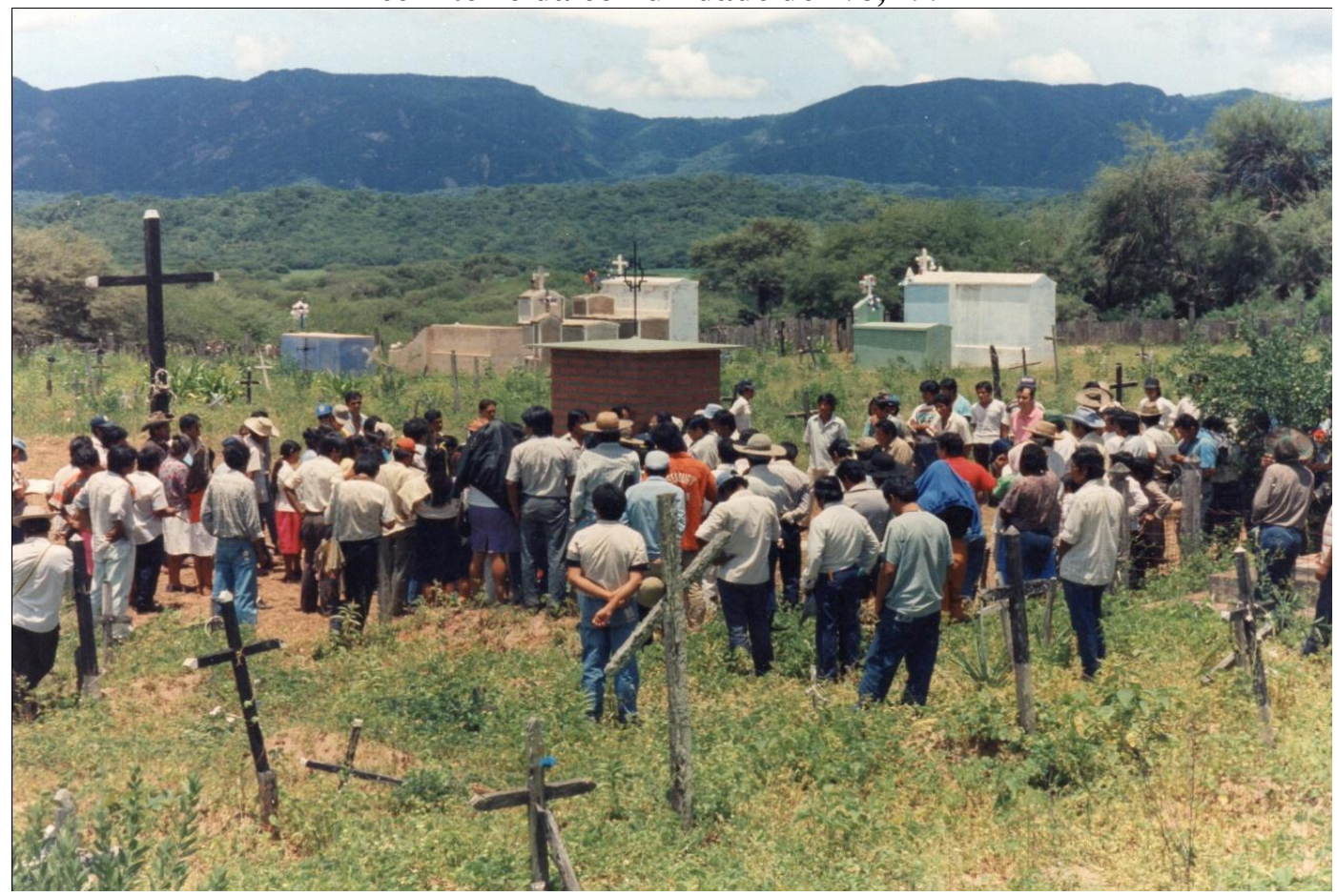

Fonte: Arquivo pessoal de Felipe Román. Crédito: Mauro Hurtado.

Figura 16. Chegada do helicóptero com presidente Jaime Paz Zamora na primeira comemoração do massacre de Kuruyuki, 1992, em Ivo

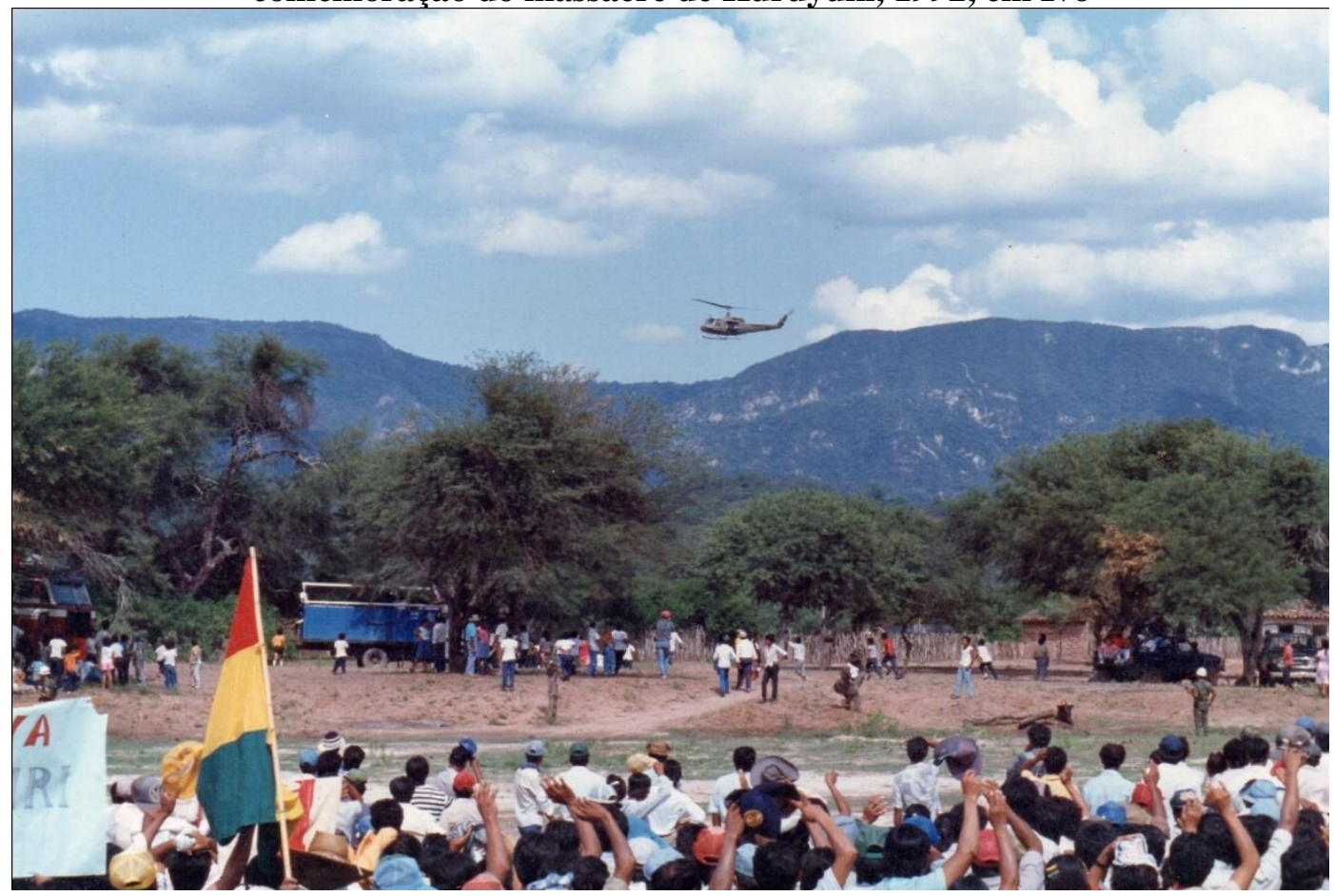

Fonte: Arquivo pessoal de Felipe Román. Crédito: Mauro Hurtado. 
Figura 17. Estátua Guerrero Chiriguano, o líder Apiaguaiki na rotatória do Segundo Anillo, próximo à Via La Guardia na cidade de Santa Cruz de la Sierra

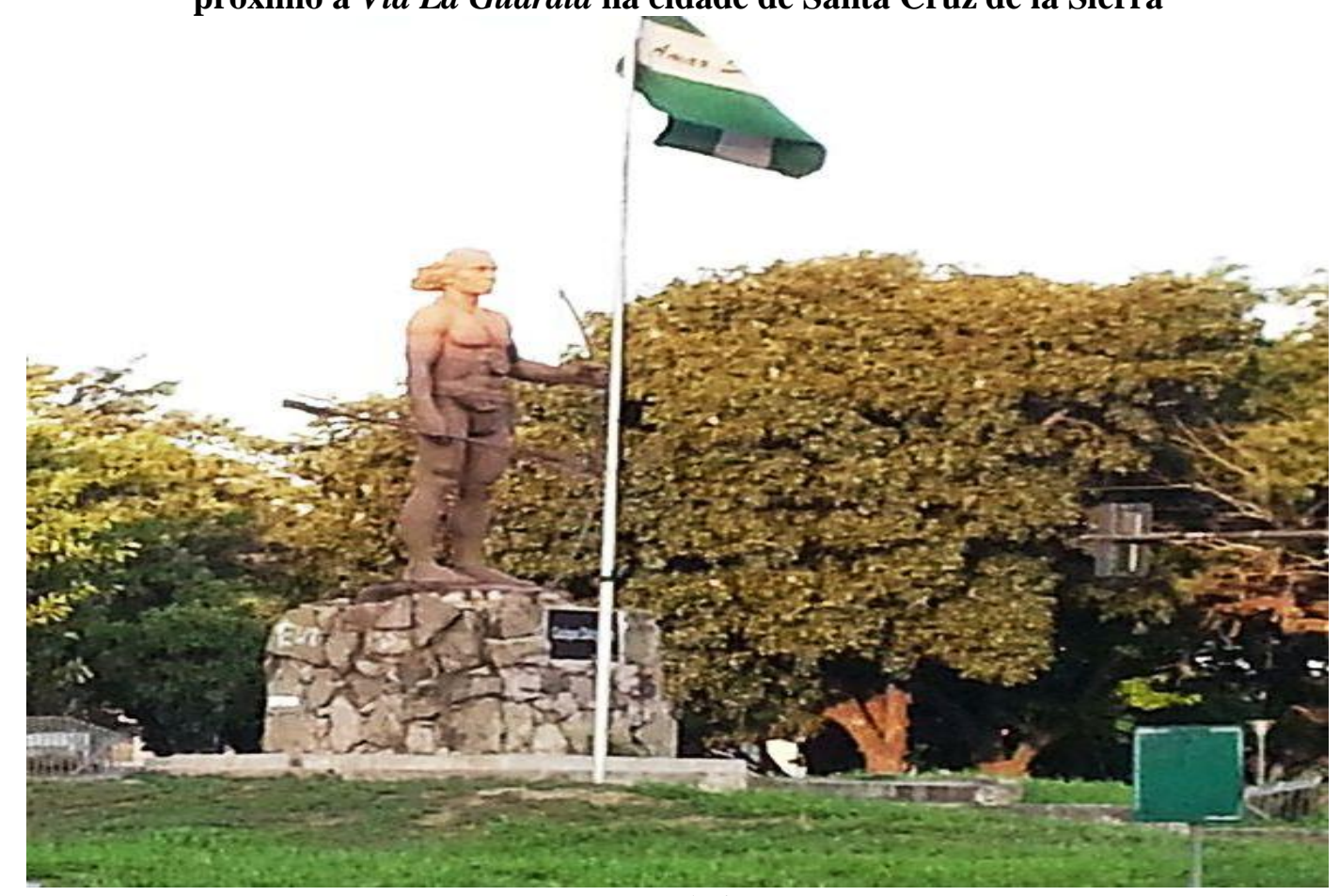

Fonte: Google imagens.

Figura 18. Estátua do guerreiro guarani Apiaguaiki com uma flecha em posição de ataque. Em

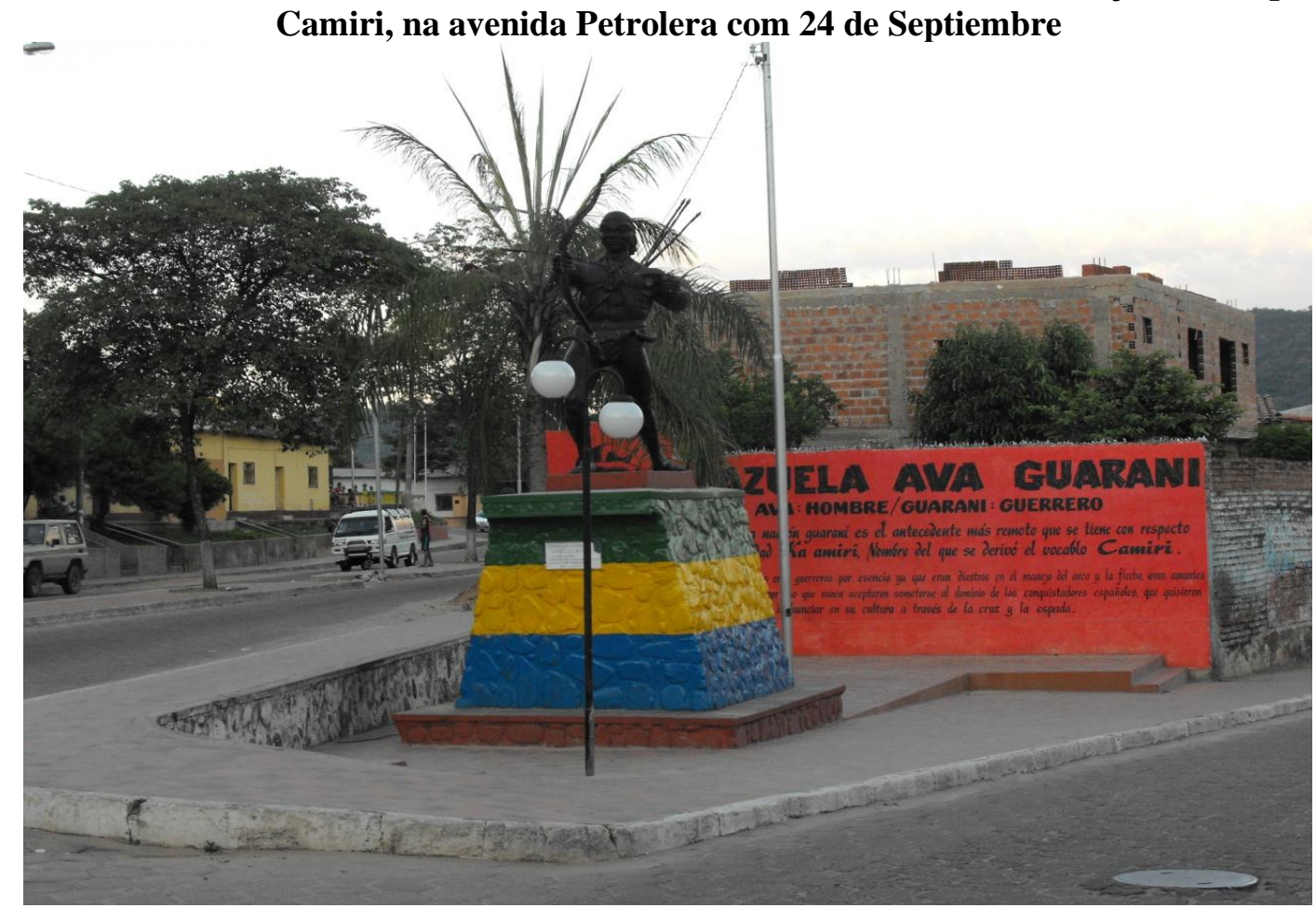

Fonte: Wildes Andrade. 
Figura 19. Em trabalho de campo entre crianças guaranis na Unidad Educativa Juan Pablo Rivero Herbas, escola indígena em Itanambikua, 2014

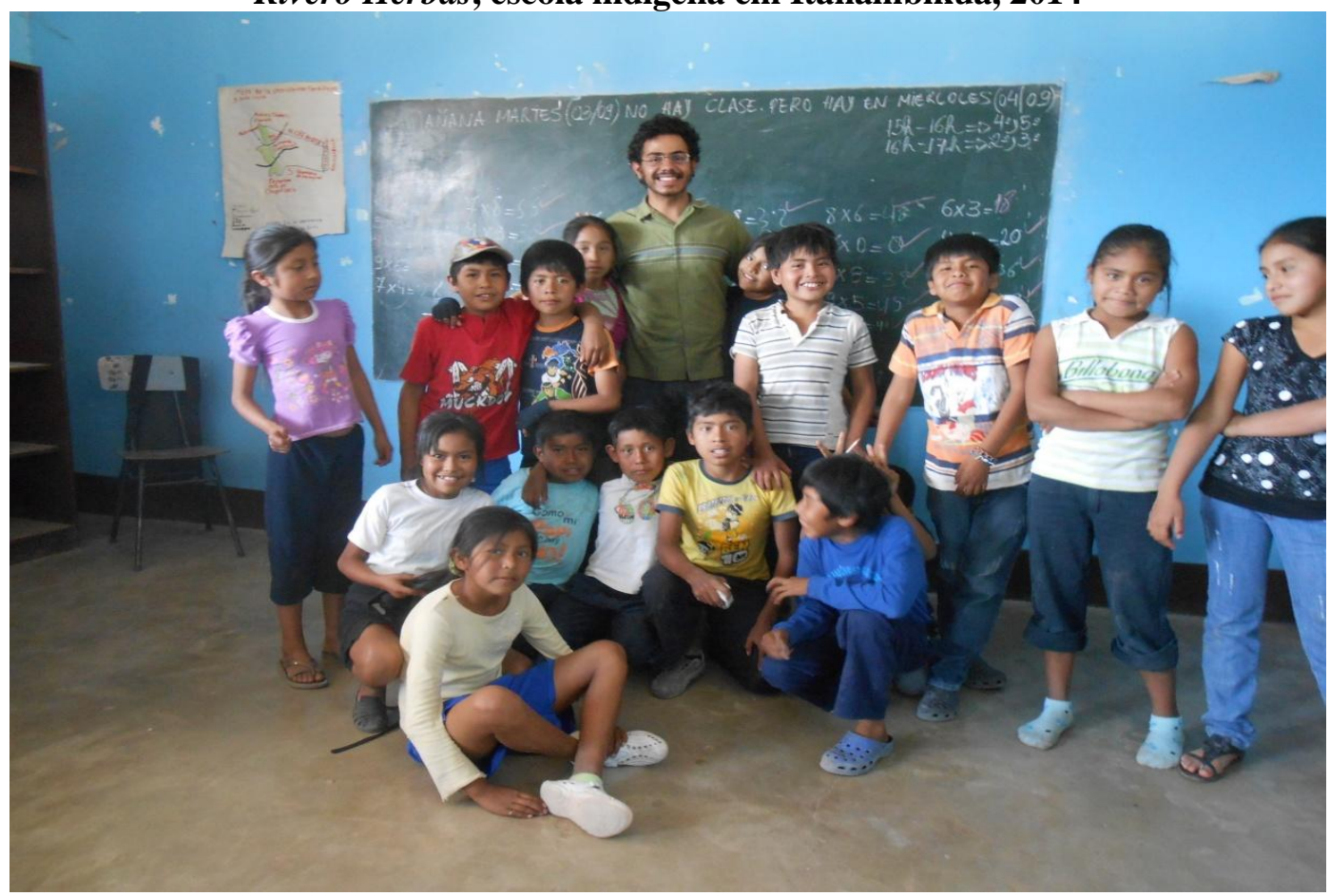

Fonte: Foto tirada por criança guarani.

Figura 20. Área onde foram realizadas as escavações de $1992 \mathrm{em}$ busca dos restos mortais, porém apresenta processo erosivo. Kuruyuki, 2014

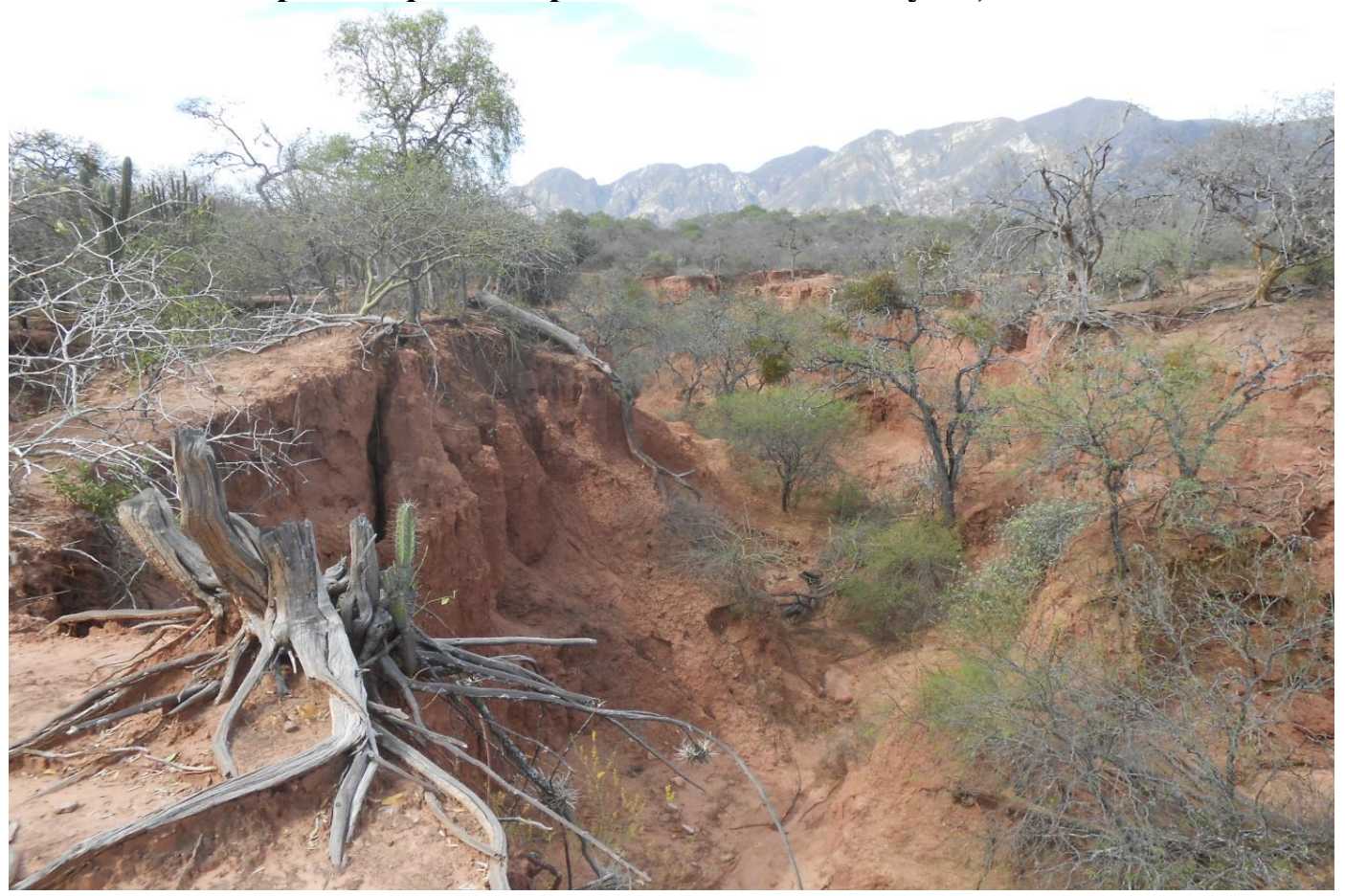

Fonte: Wildes Andrade. 
Figura 21. Felipe Román mostrando cerâmicas encontradas na área em que realizou as escavações de 1992 em busca dos restos mortais. Kuruyuki, 2014

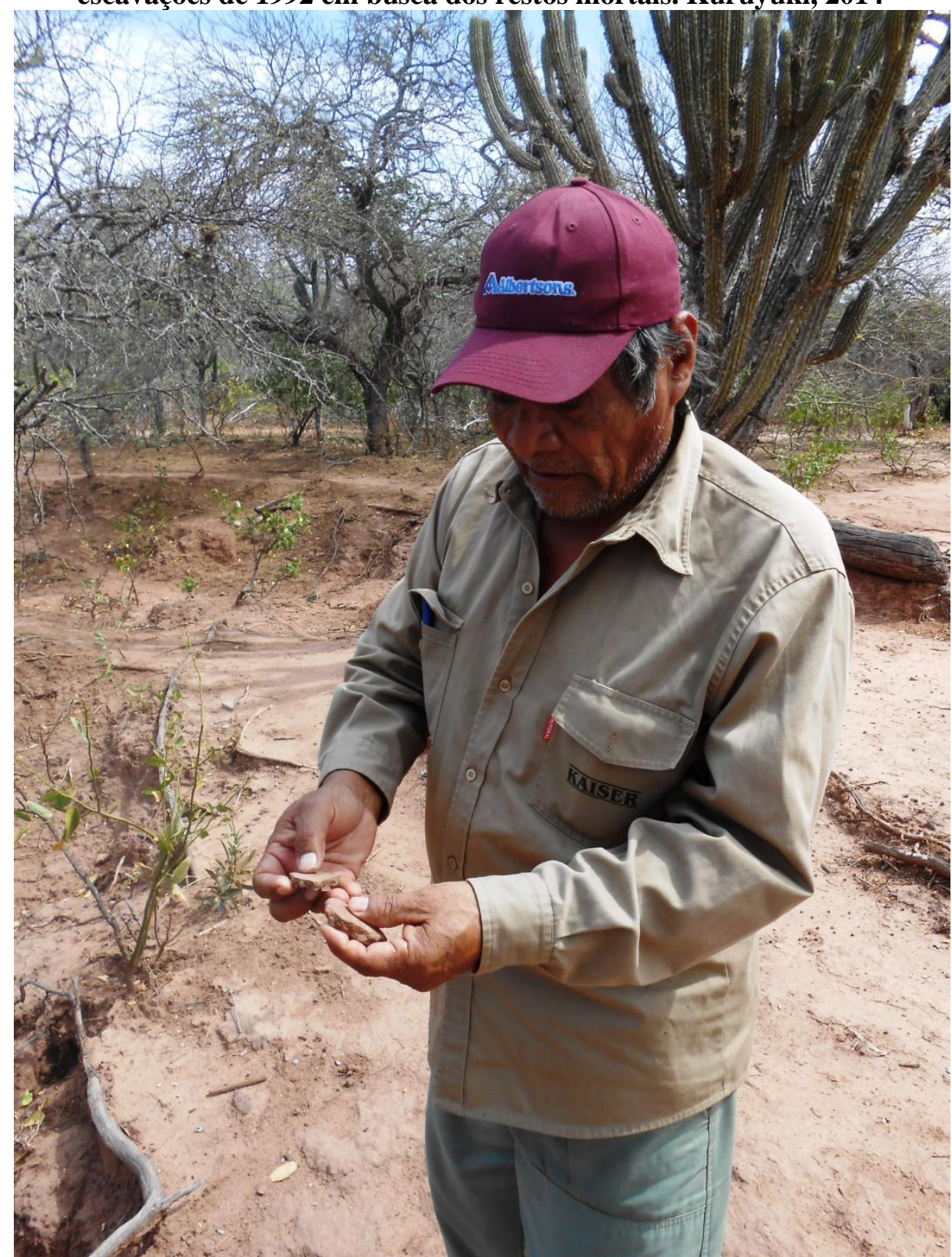

Fonte: Wildes Andrade. 
Figura 22. Iglesia San Boaventura, Ivo, 2014

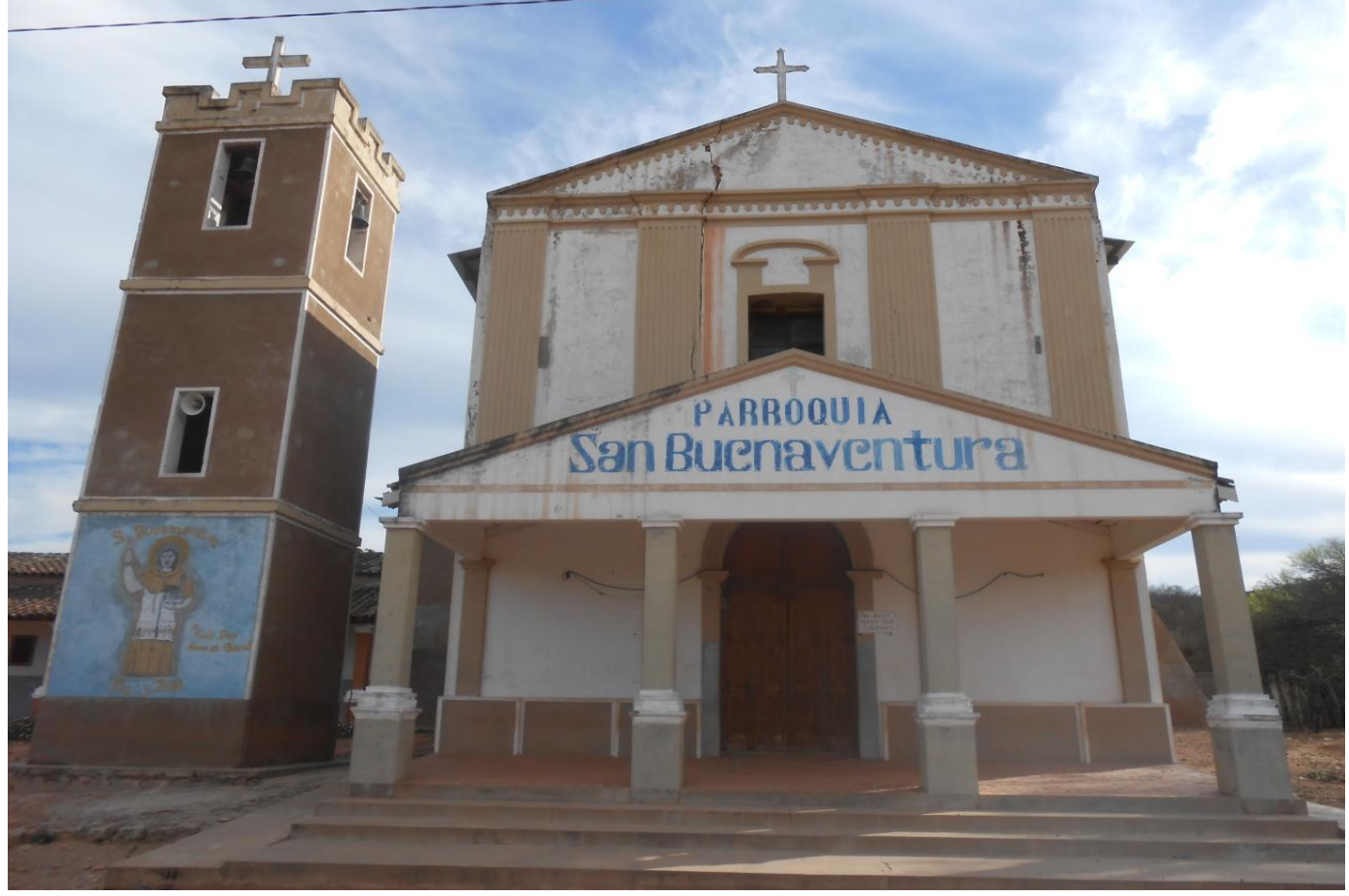

Fonte: Wildes Andrade.

Figura 23. Cruz em homenagem aos mortos no massacre de Kuruyuki, em frente à Iglesia San Boaventura, Ivo, 2014

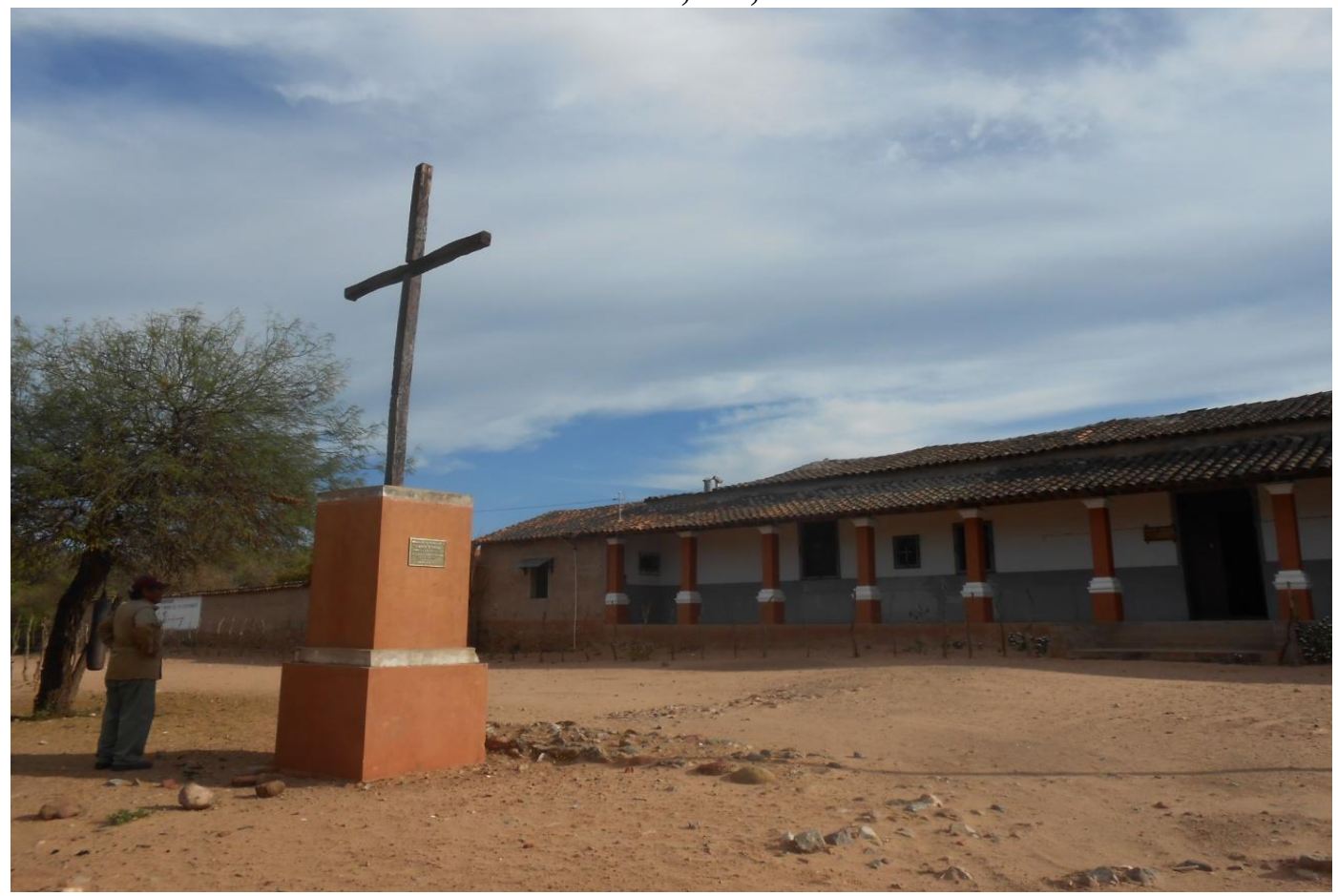

Fonte: Wildes Andrade. 
Figura 24. Placa recordatória da Cruz aos mortos em Kuruyuki em frente à Igreja de Ivo, 2014

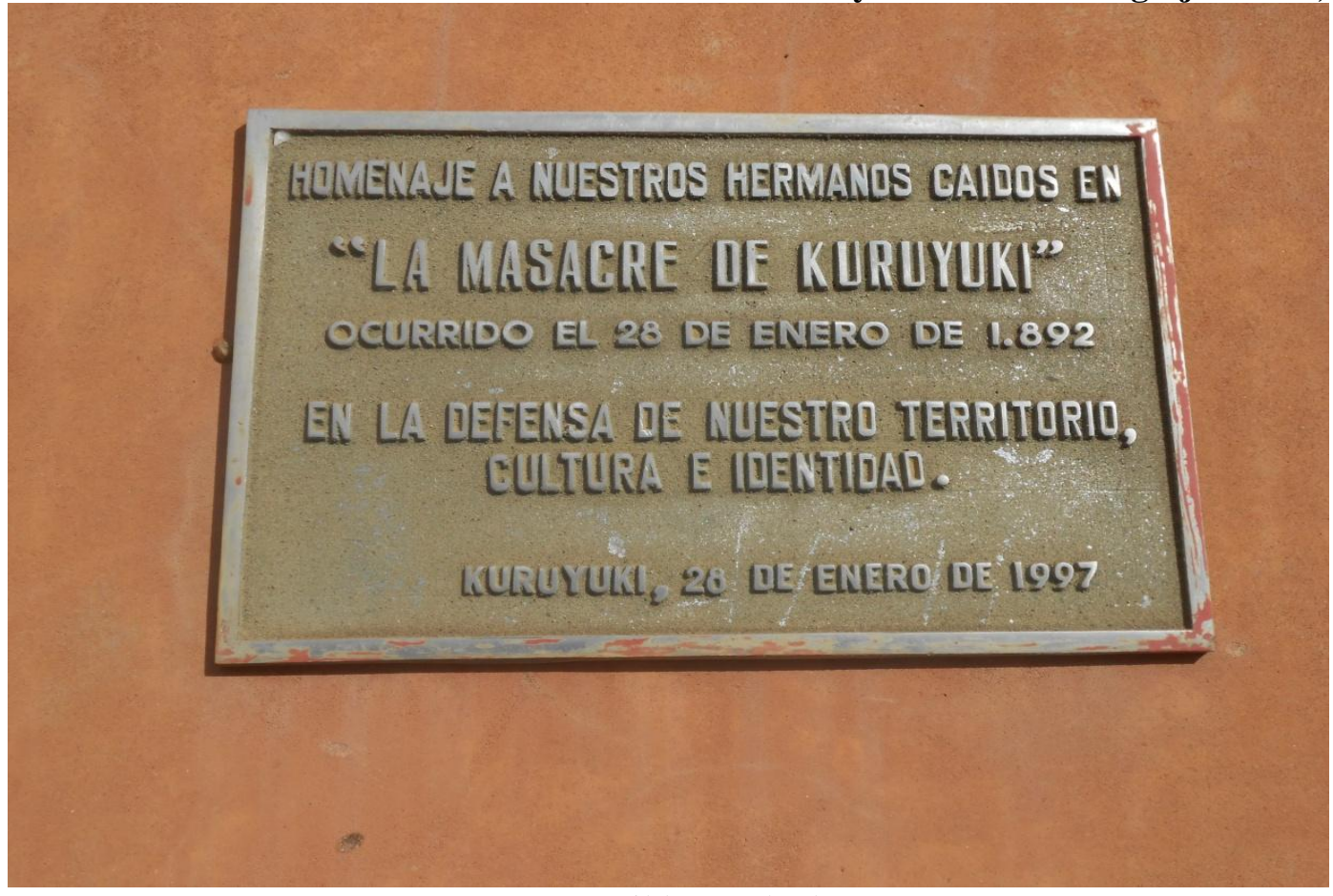

Fonte: Wildes Andrade.

Figura 25. Rua principal da comunidade de Ivo, 2014

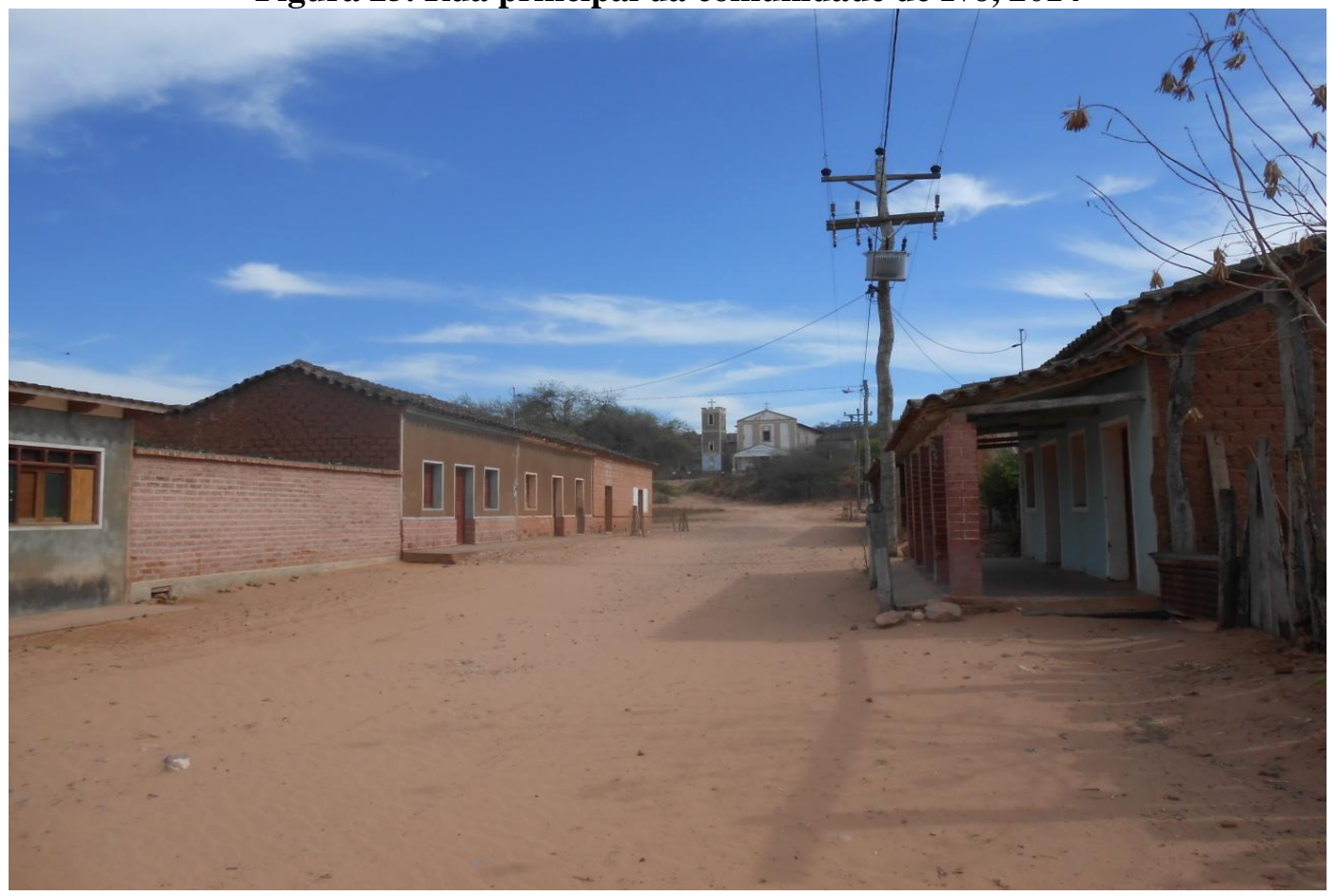

Fonte: Wildes Andrade. 
Figura 26. Palanque/salão de festa na comunidade de Ivo, local onde acontecem os atos cívicos da comemoração de Kuruyuki, 2014

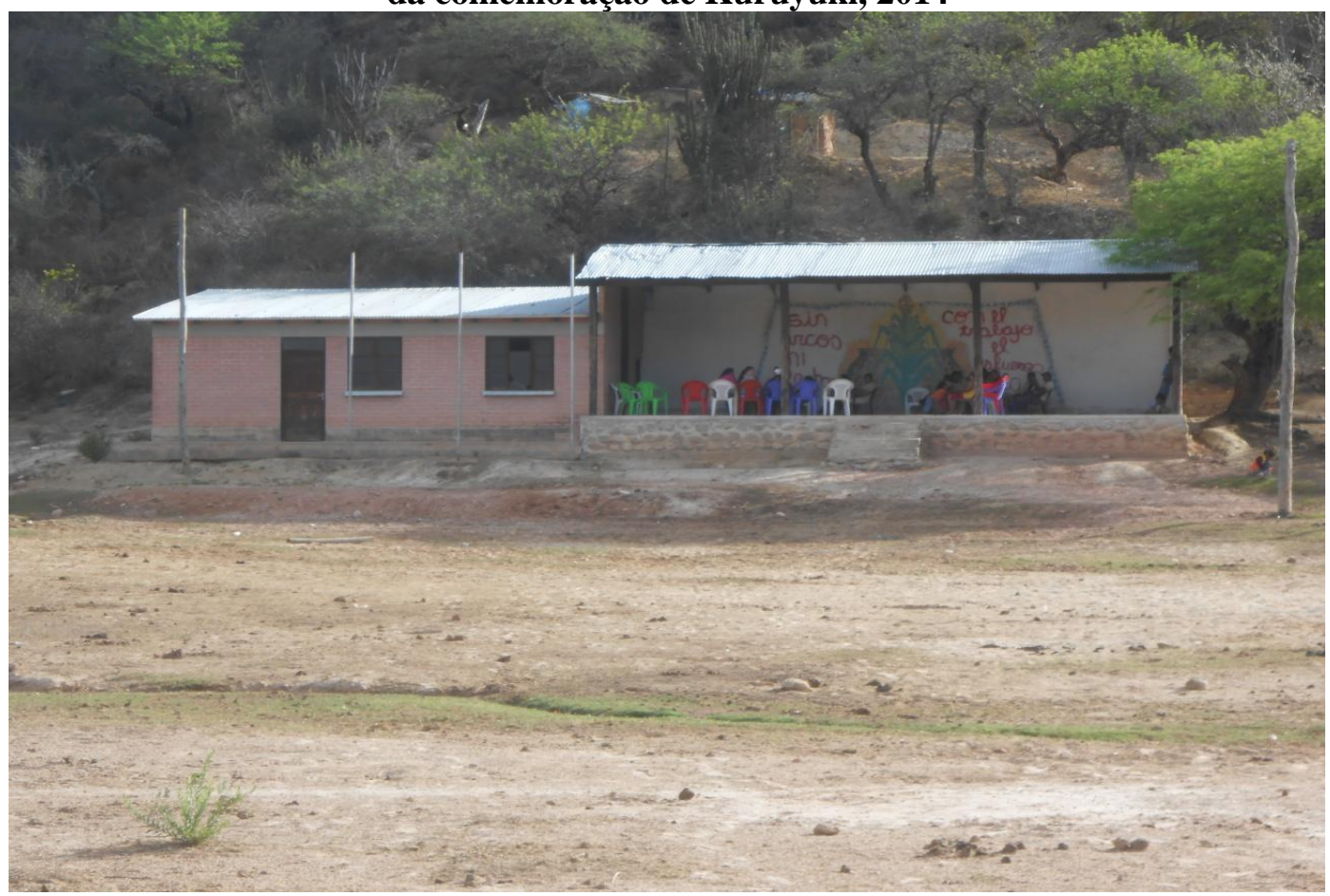

Fonte: Wildes Andrade.

Figura 27. As trincheiras do massacre em Kuruyuki, 2014

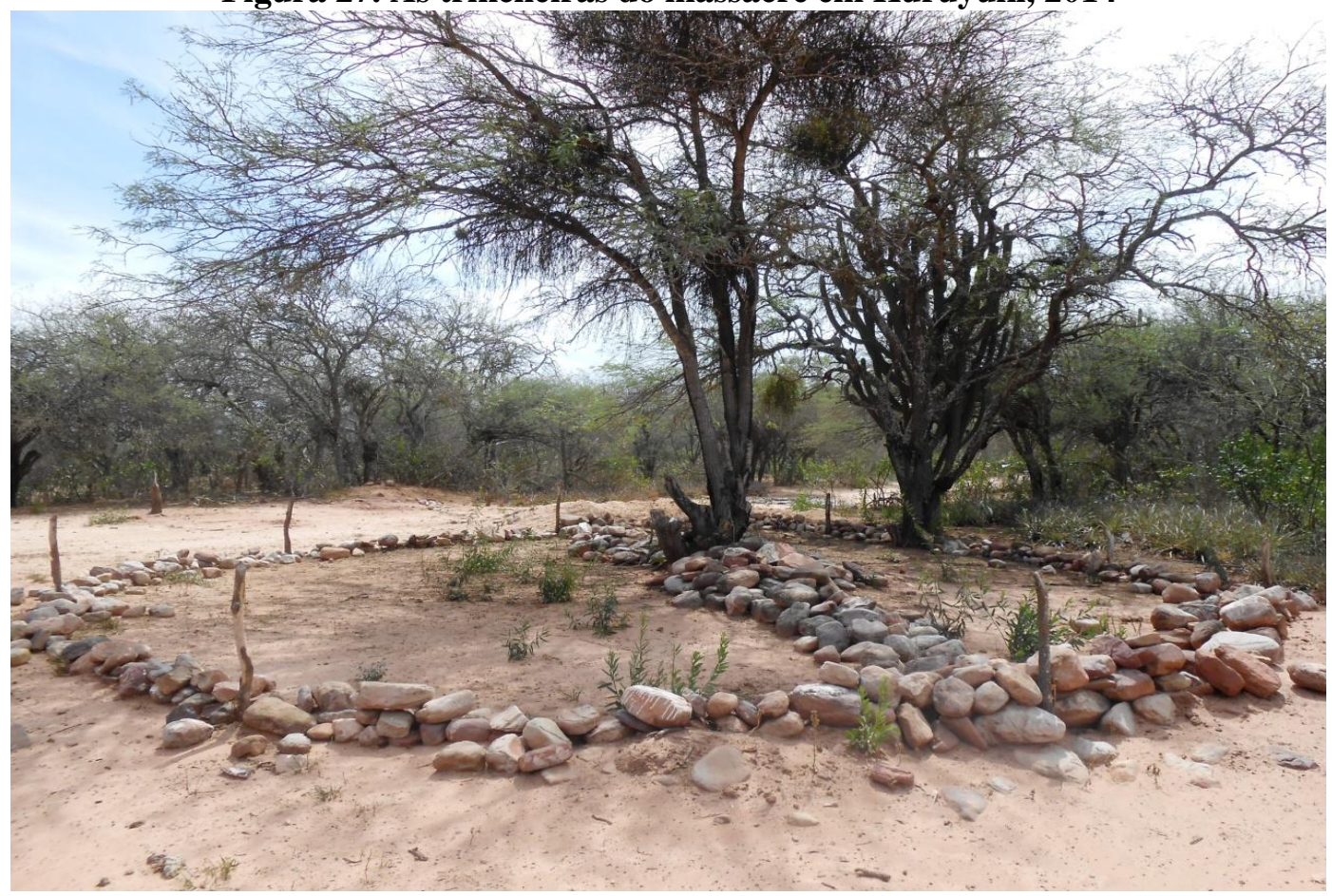

Fonte: Wildes Andrade. 
Figura 28. Vista panorâmica da Unibol, Kuruyuki, 2013

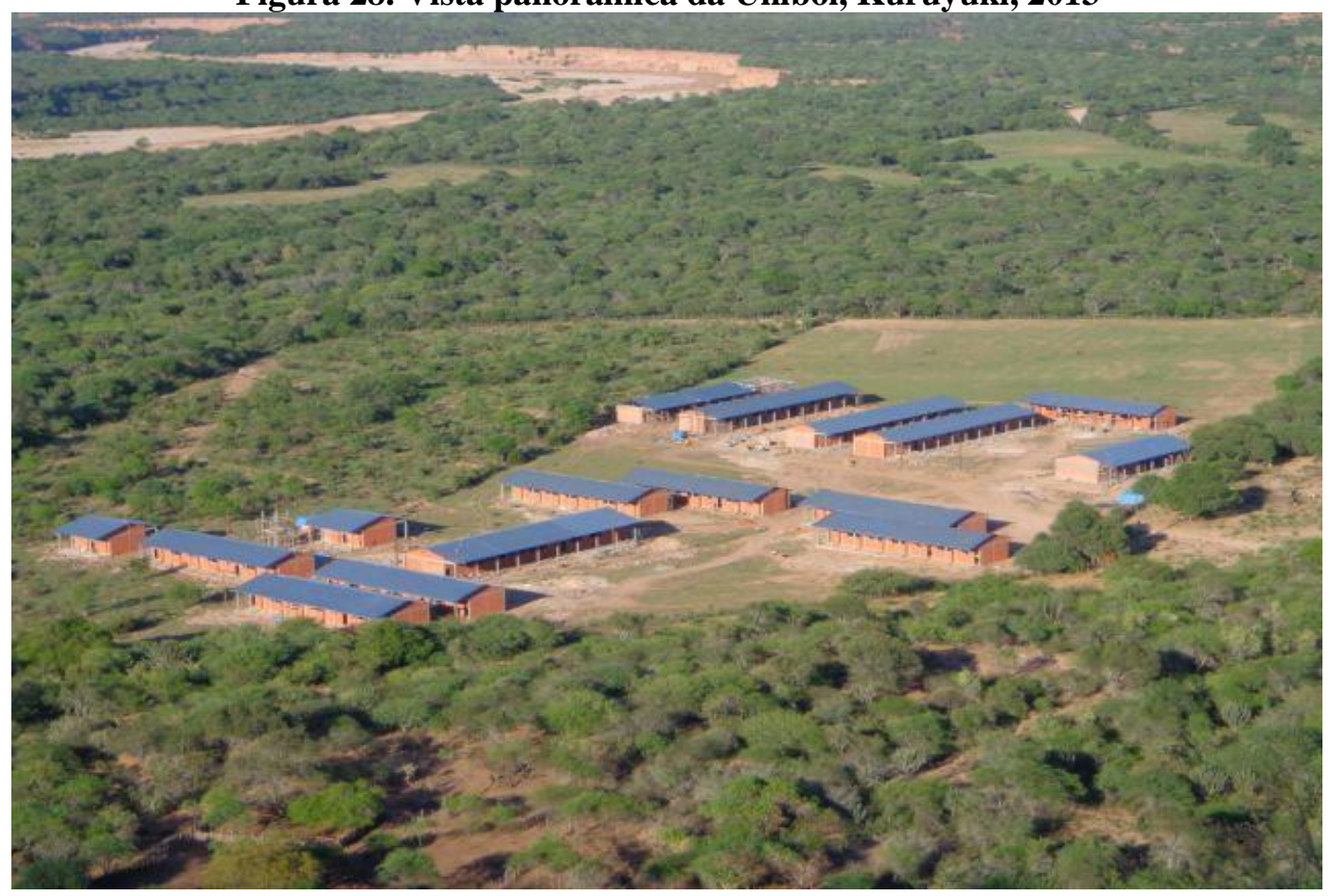

Fonte: <comunicacion.gob.bo>.

Figura 29. VIII Marcha Indígena, 11 de outubro de 2011. Participação da APG com bandeira da nação guarani: única bandeira com azul

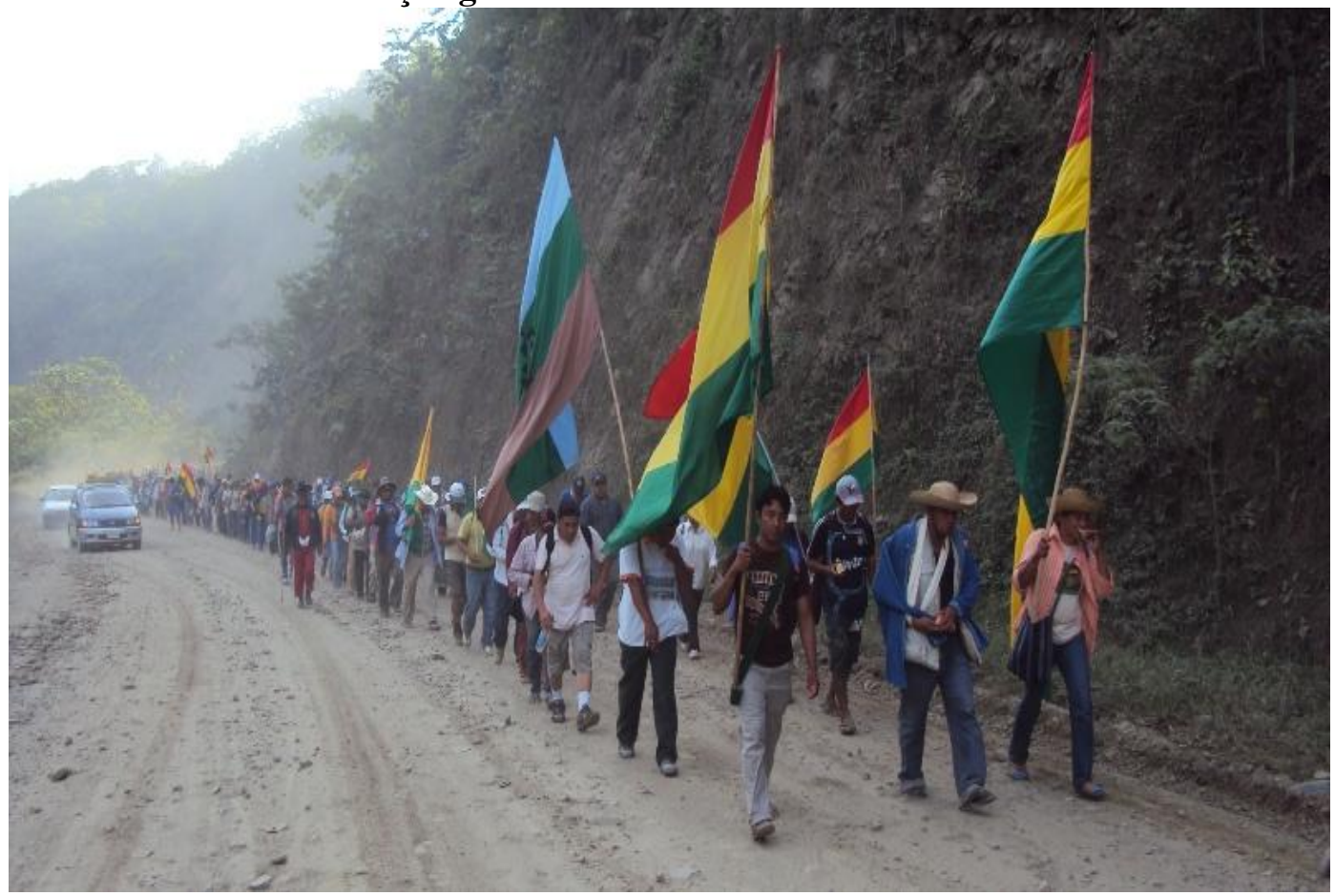

Fonte: Google imagens. 
Figura 30. Ossuário com restos mortais dos guerreiros do massacre de Kuruyuki. Cemitério de Ivo, 2004

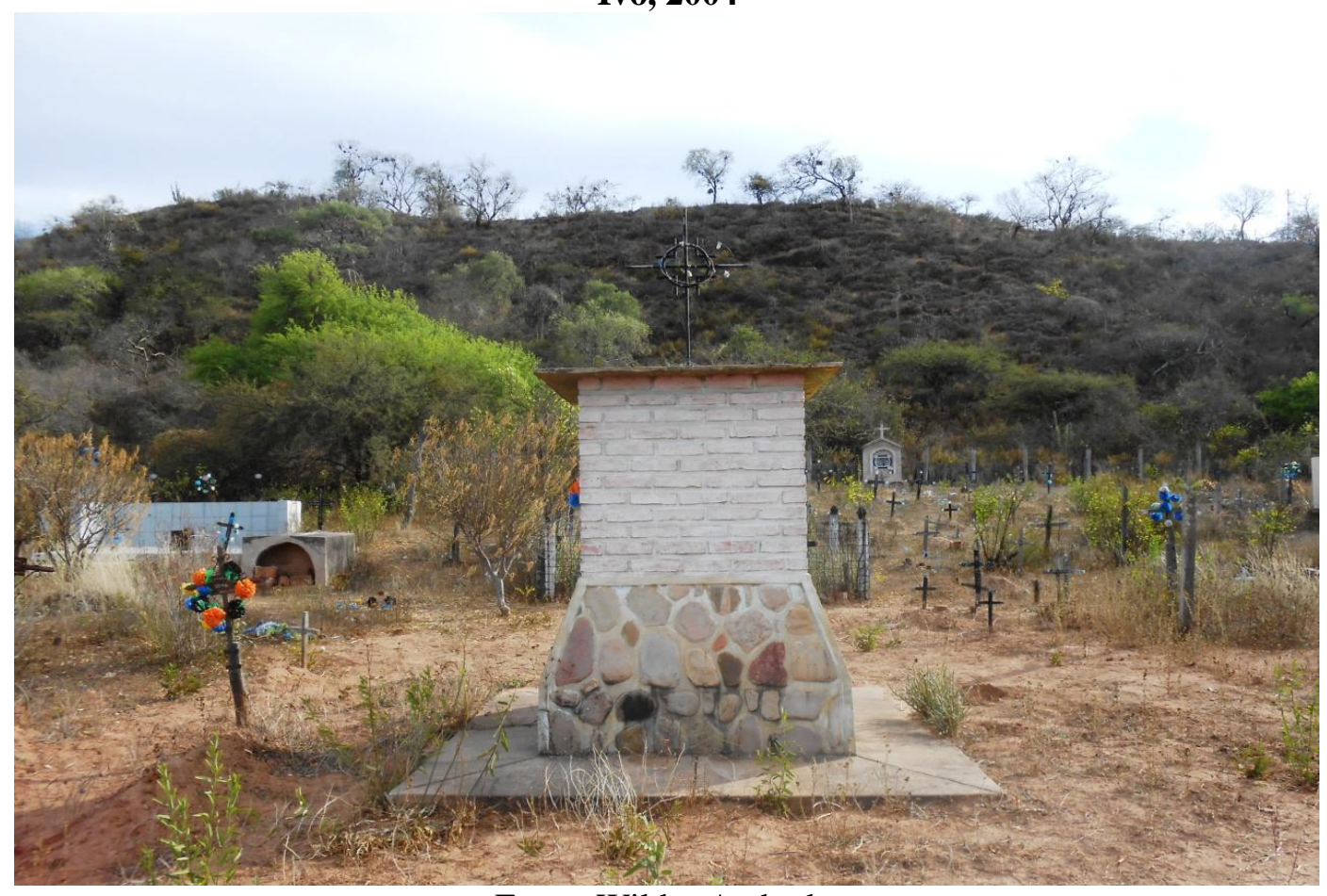

Fonte: Wildes Andrade.

Figura 31. Translado dos ossos dos guerreiros em urnas funerárias para o Cemitério em Ivo, 1992

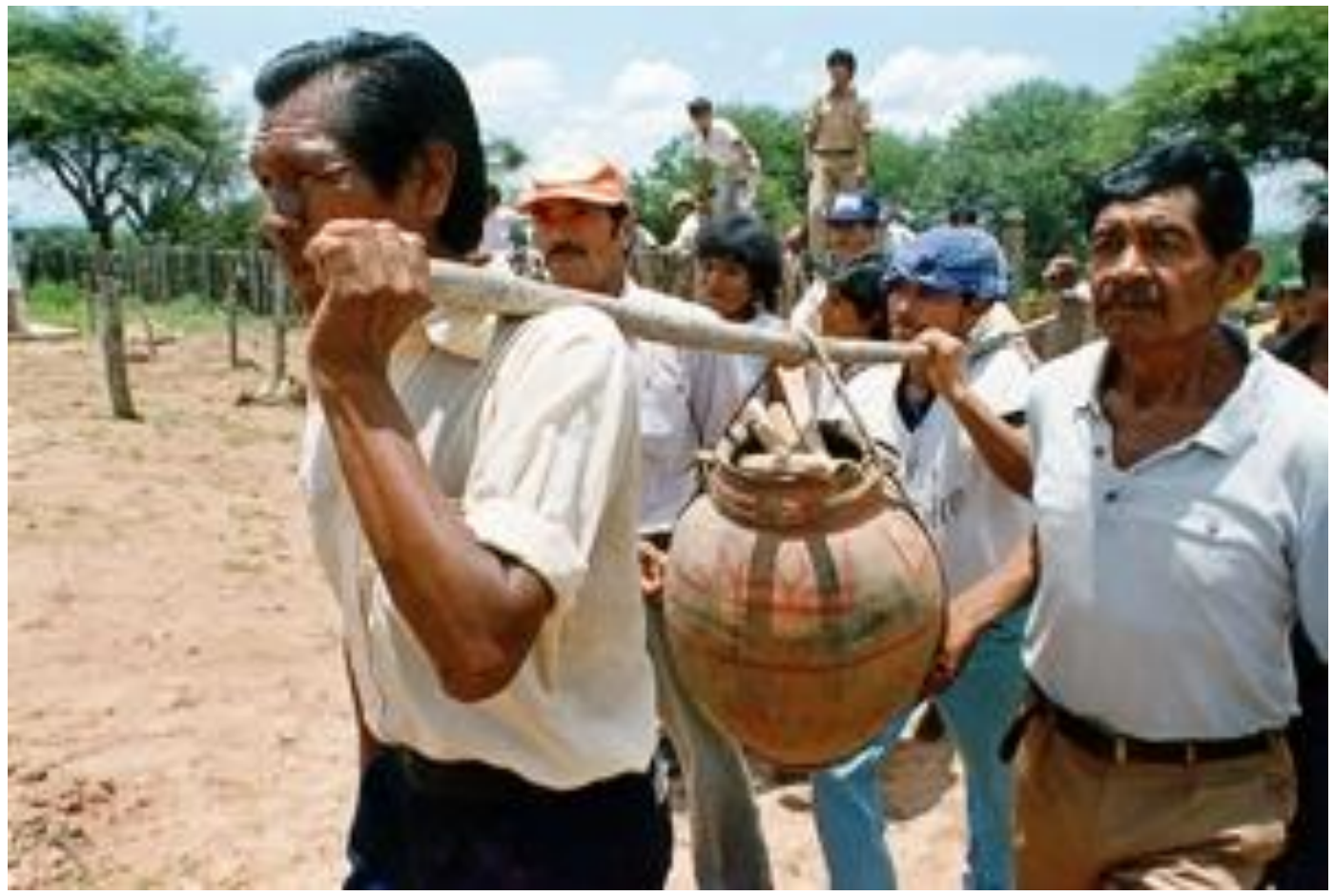

Fonte: Google imagens. 
Figura 32. Casal guarani de Macharetí dança na comemoração de Kuruyuki de 2008

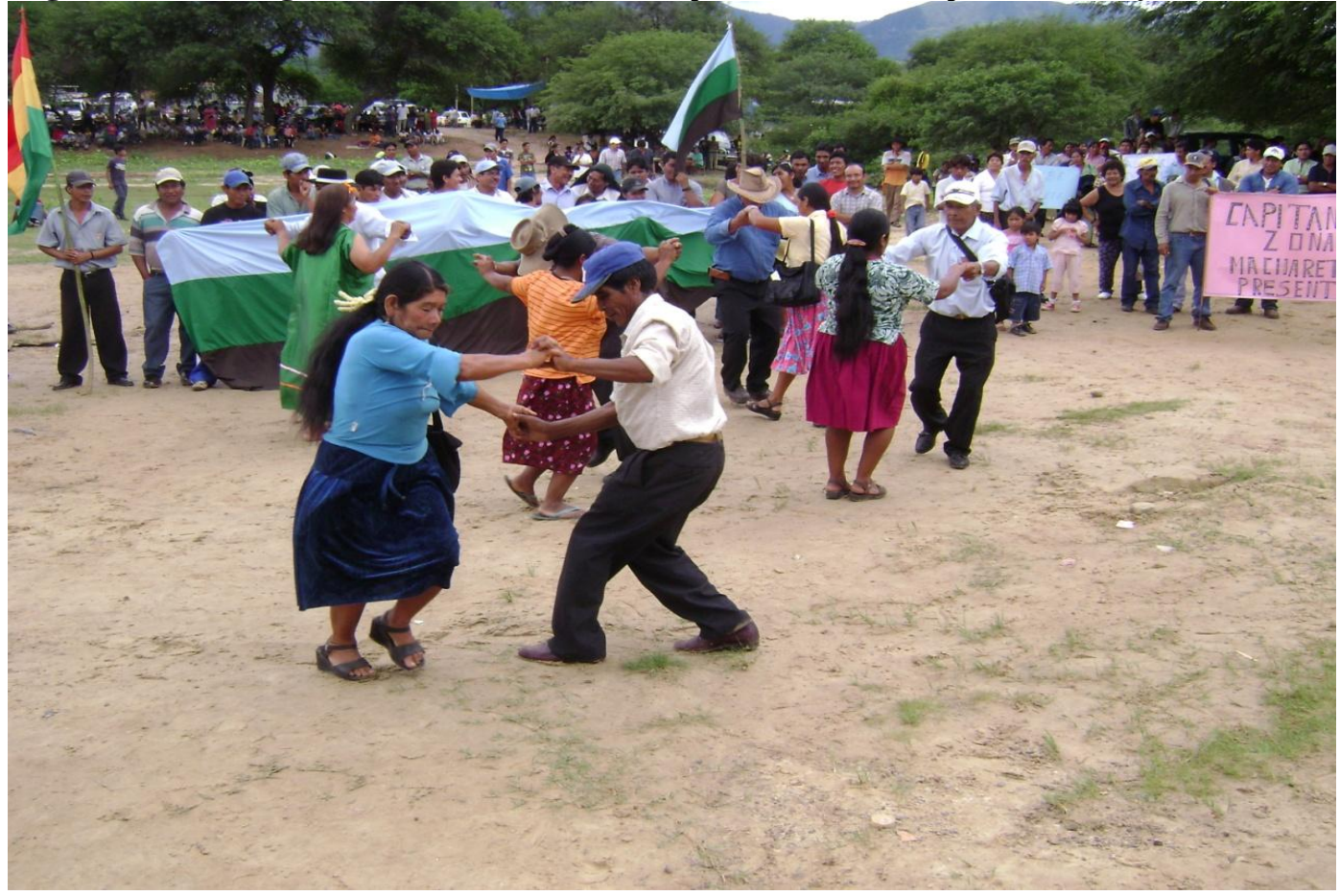

Fonte: CIPCA Cordillera.

Figura 33. Palanque na comemoração de Kuruyuki de 2008
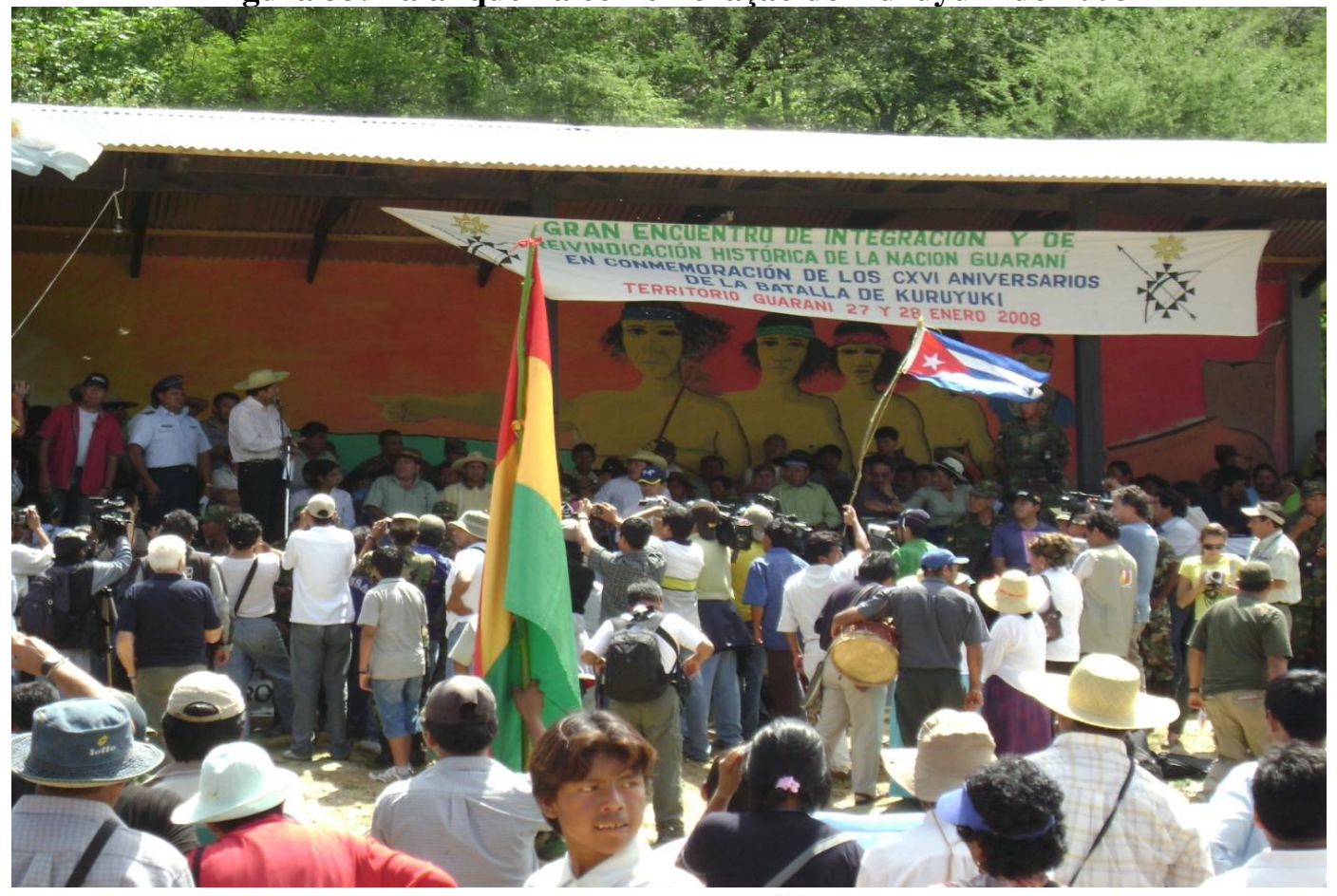

Fonte: CIPCA Cordillera. 
Figura 34. Pessoas se escondem do forte sol do Chaco na comemoração de Kuruyuki de 2009, Ivo

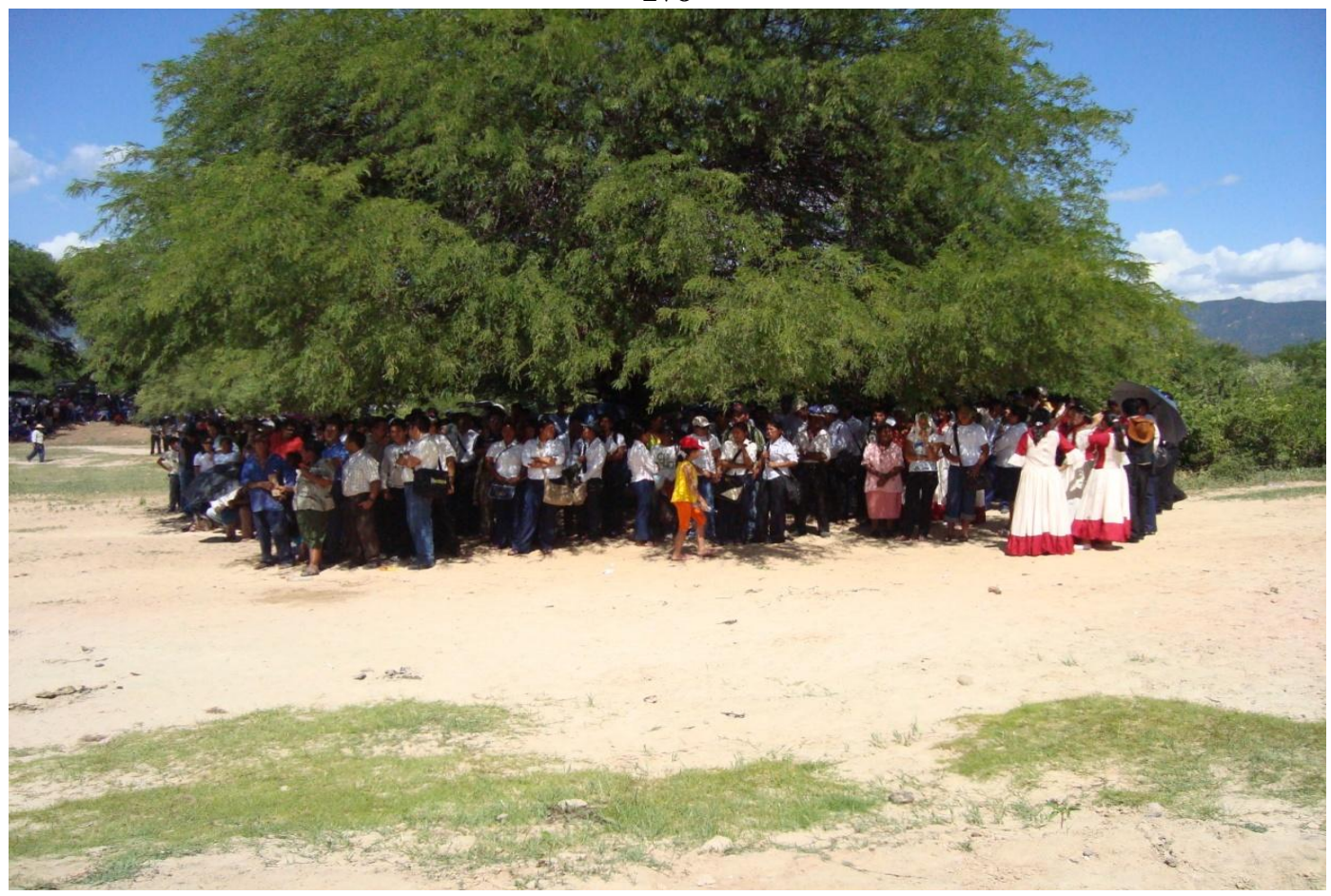

Fonte: CIPCA Cordillera.

Figura 35. Venda de cerâmica guarani na comemoração de Kuruyuki de 2010, Ivo

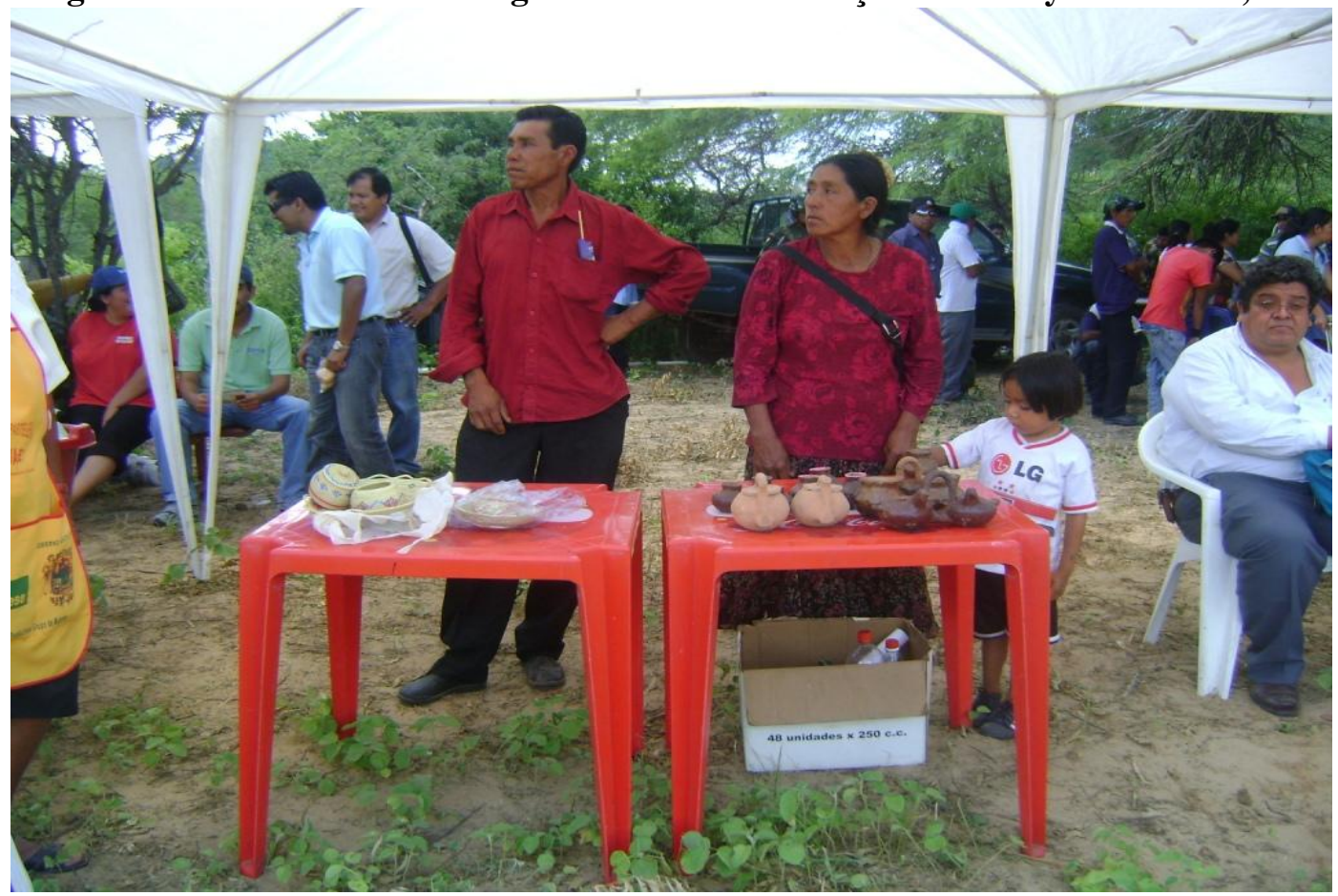

Fonte: CIPCA Cordillera. 
Figura 36. Presença do Exército na comemoração de Kuruyuki de 2010, Ivo

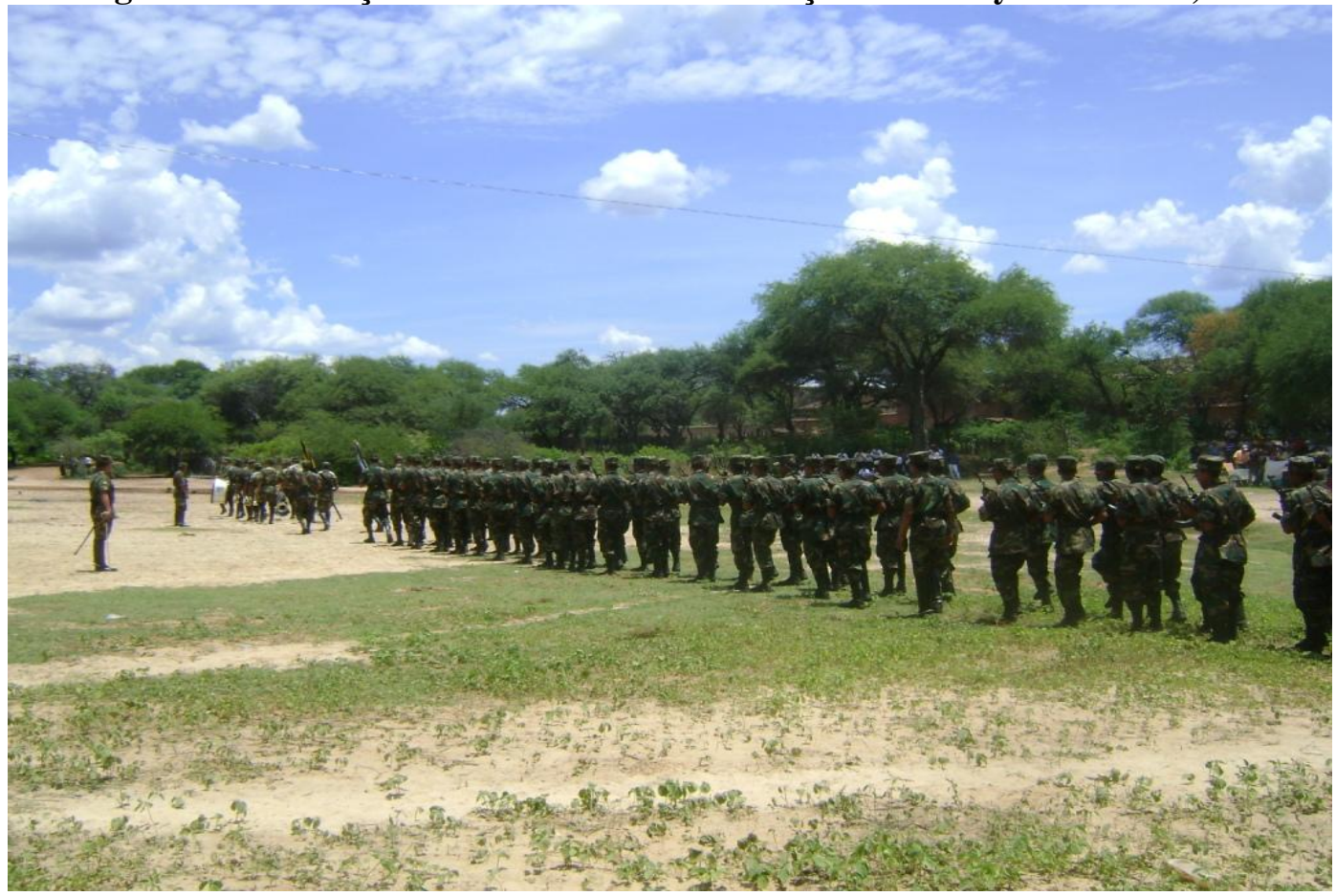

Fonte: CIPCA Cordillera.

Figura 37. Pessoas durante a comemoração de Kuruyuki de 2010, Ivo

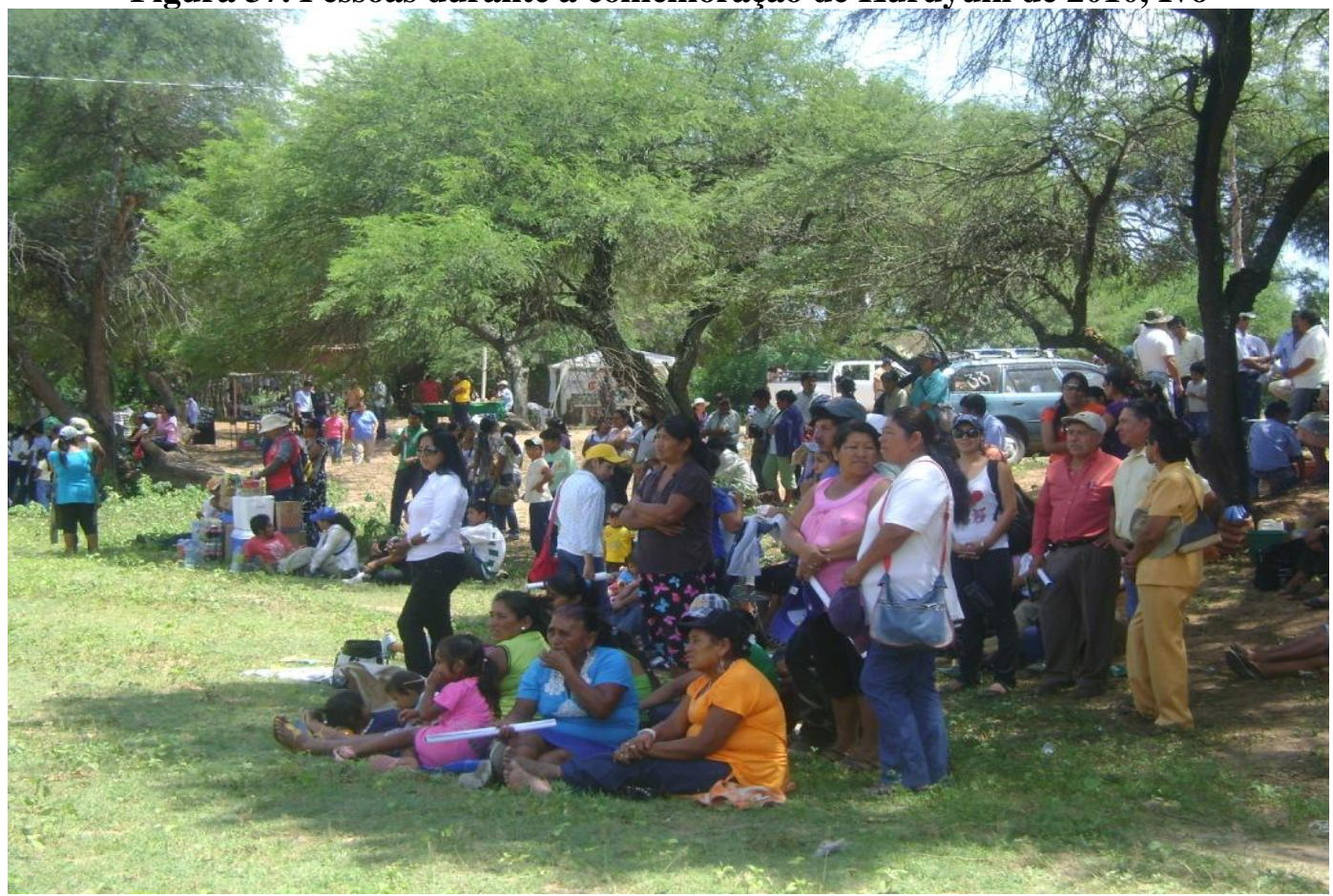

Fonte: CIPCA Cordillera. 
Figura 38. Orquestra de Palmarito durante a comemoração de Kuruyuki de 2010, Ivo

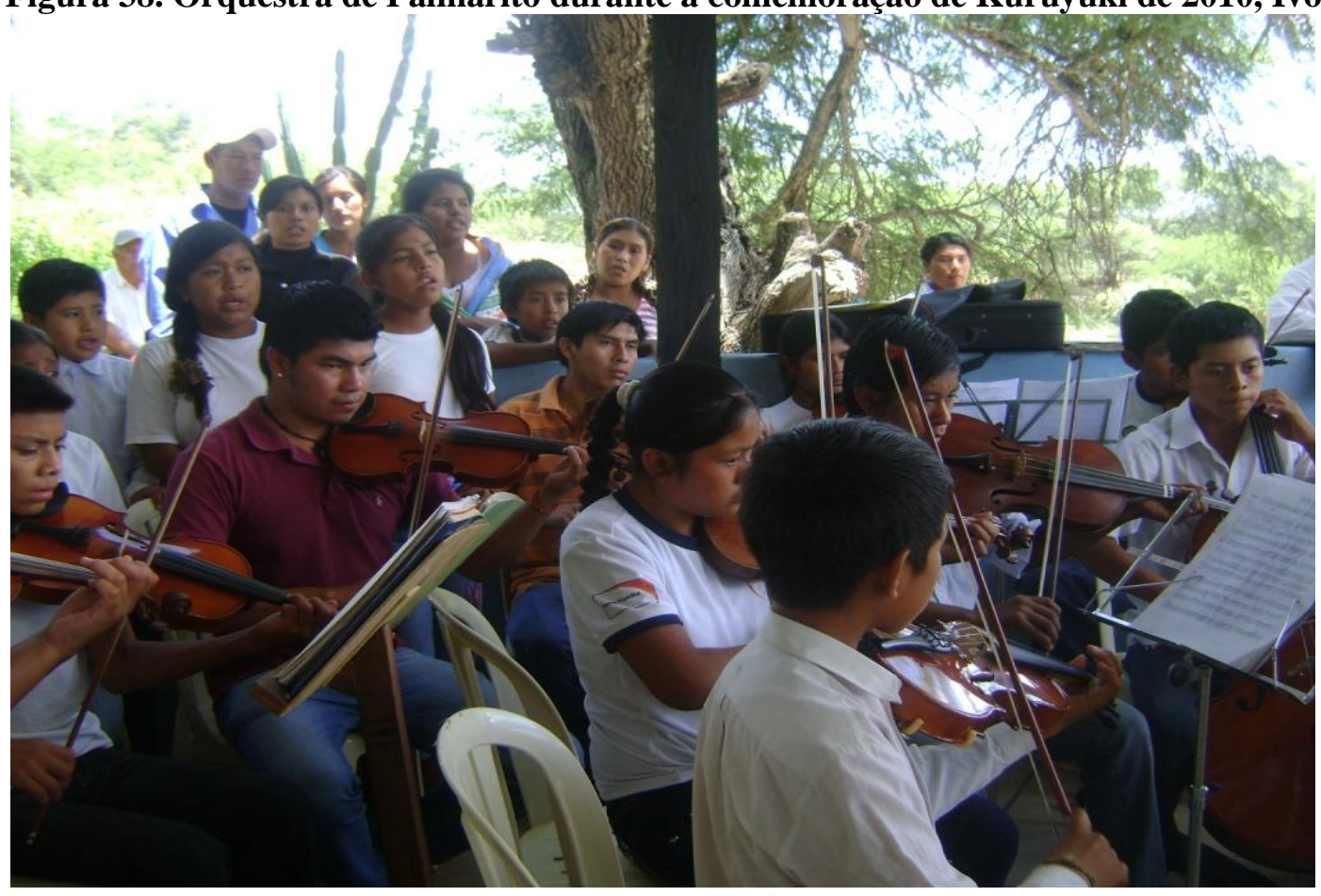

Fonte: CIPCA Cordillera.

Figura 39. Alunas da Escola Normal de Camiri cantando o Hino a Kuruyuki na comemoração de 2010, Ivo

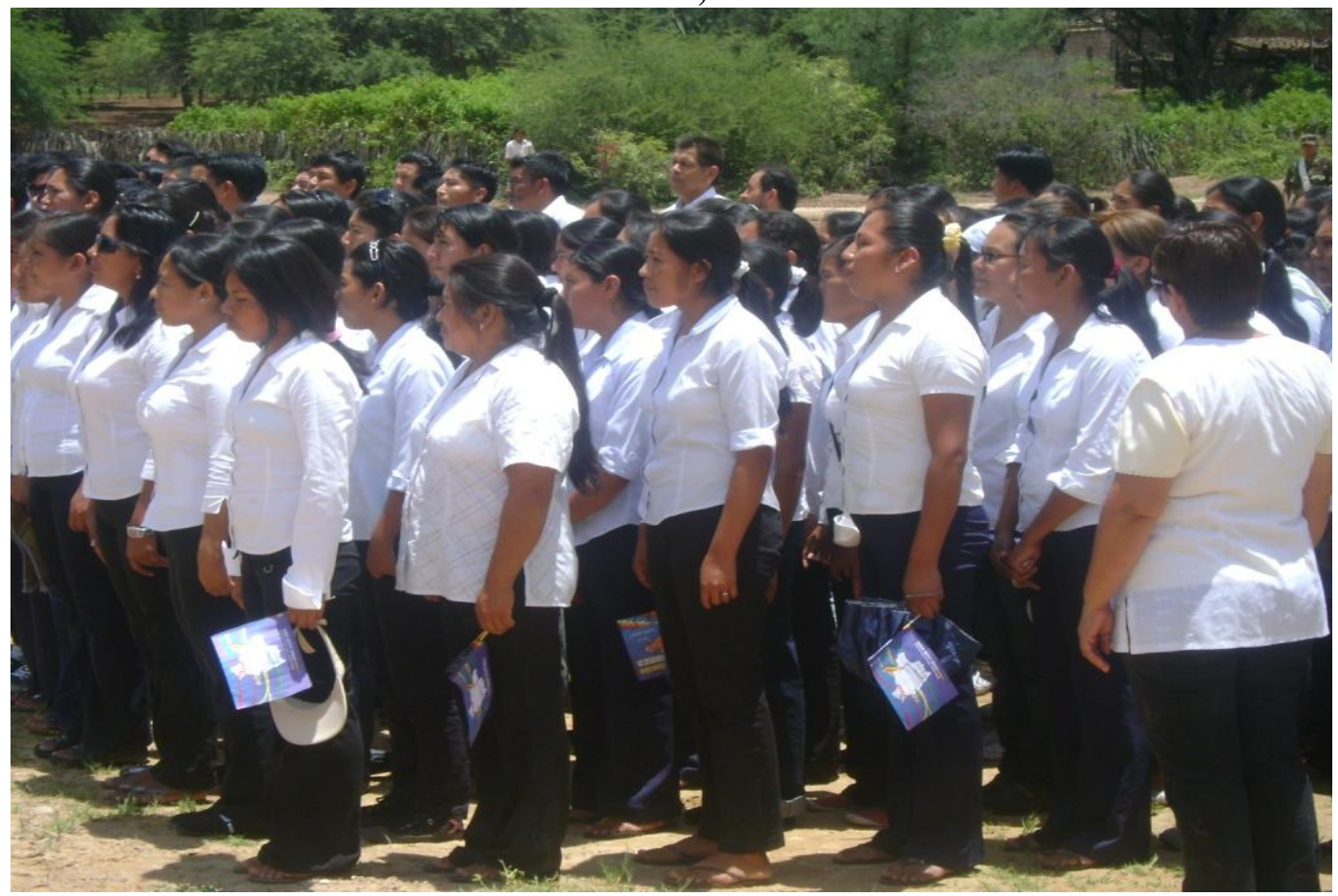

Fonte: CIPCA Cordillera. 
Figura 40. Wilson Changaray Taborga, ex-presidente da APG Nacional e atual deputado guarani, hasteando a bandeira guarani na comemoração de 2010, Ivo

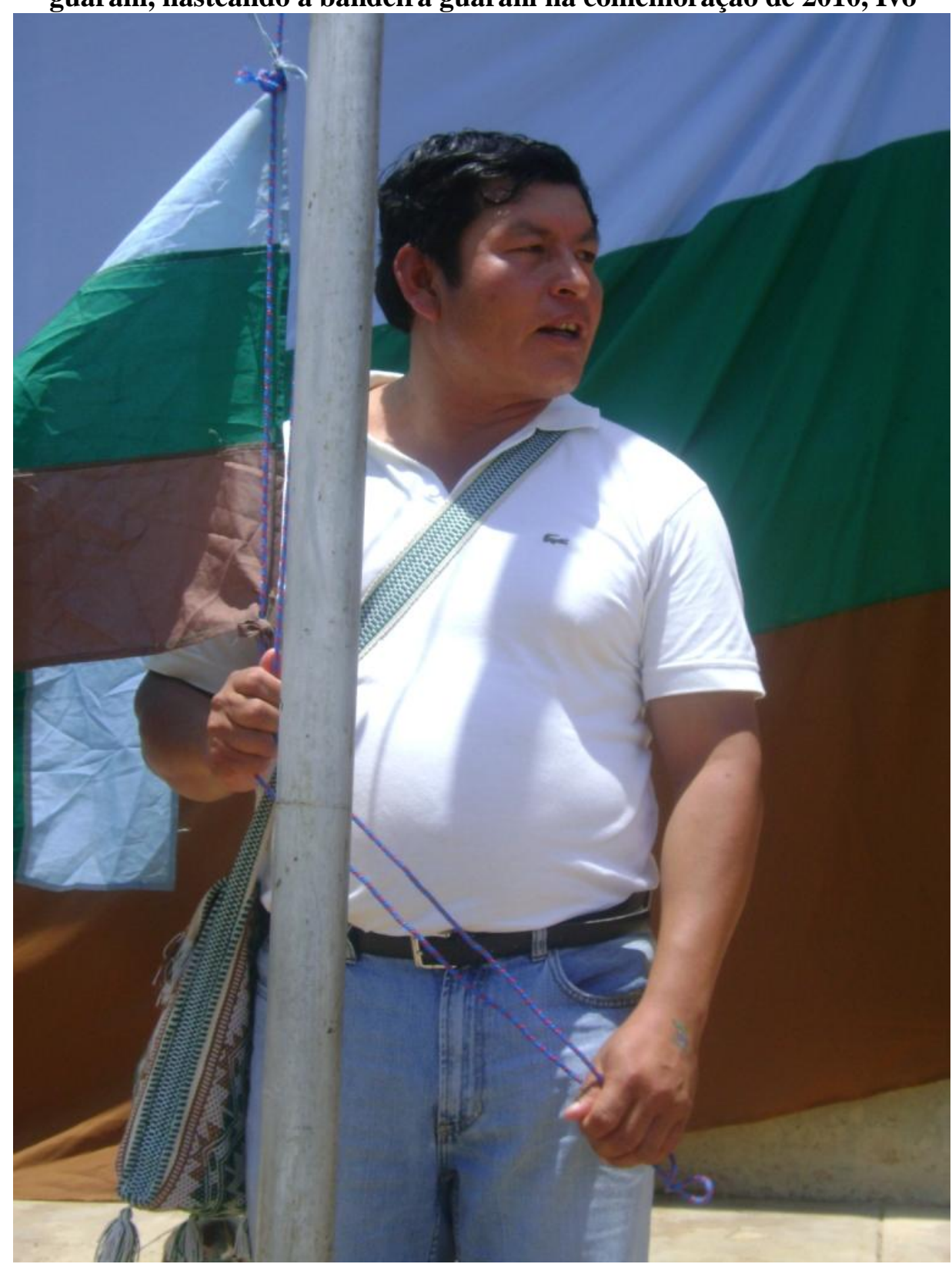

Fonte: CIPCA Cordillera. 
Figura 41. Em diálogo no centro da foto: presidente da APG Nacional, Faustino Flores e o presidente Evo Morales, na comemoração de 2013, Ivo

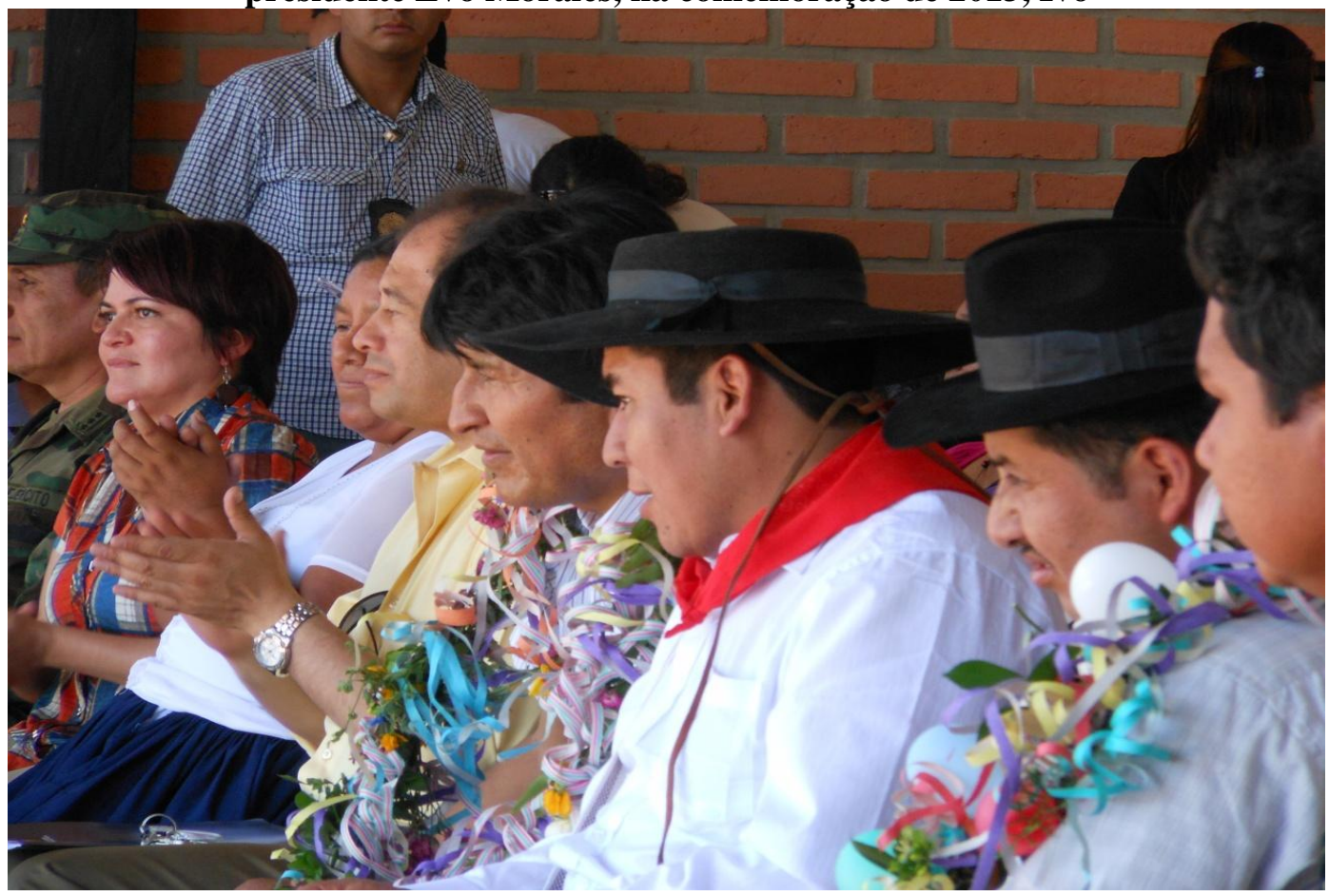

Fonte: CIPCA Cordillera.

Figura 42. Nelson Bartolo, secretário de Recursos Naturais da APG Nacional, entregando um projeto para o presidente Morales na comemoração de 2013, Ivo

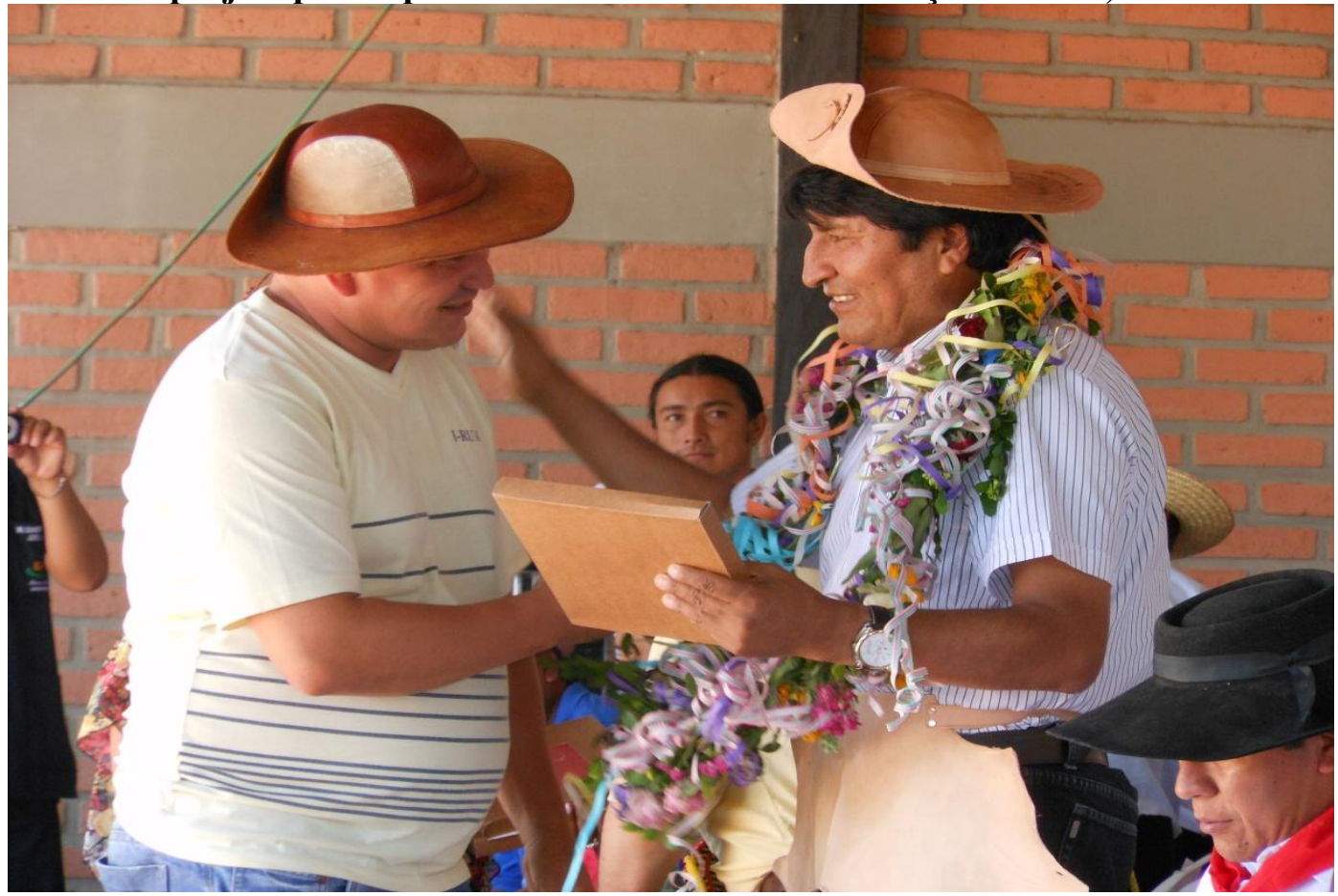

Fonte: CIPCA Cordillera. 
Figura 43. Cartaz do filme Yvy maraey - Tierra sin mal, do diretor Juan Carlos Valdivia, sobre a nação guarani, lançado em 2013

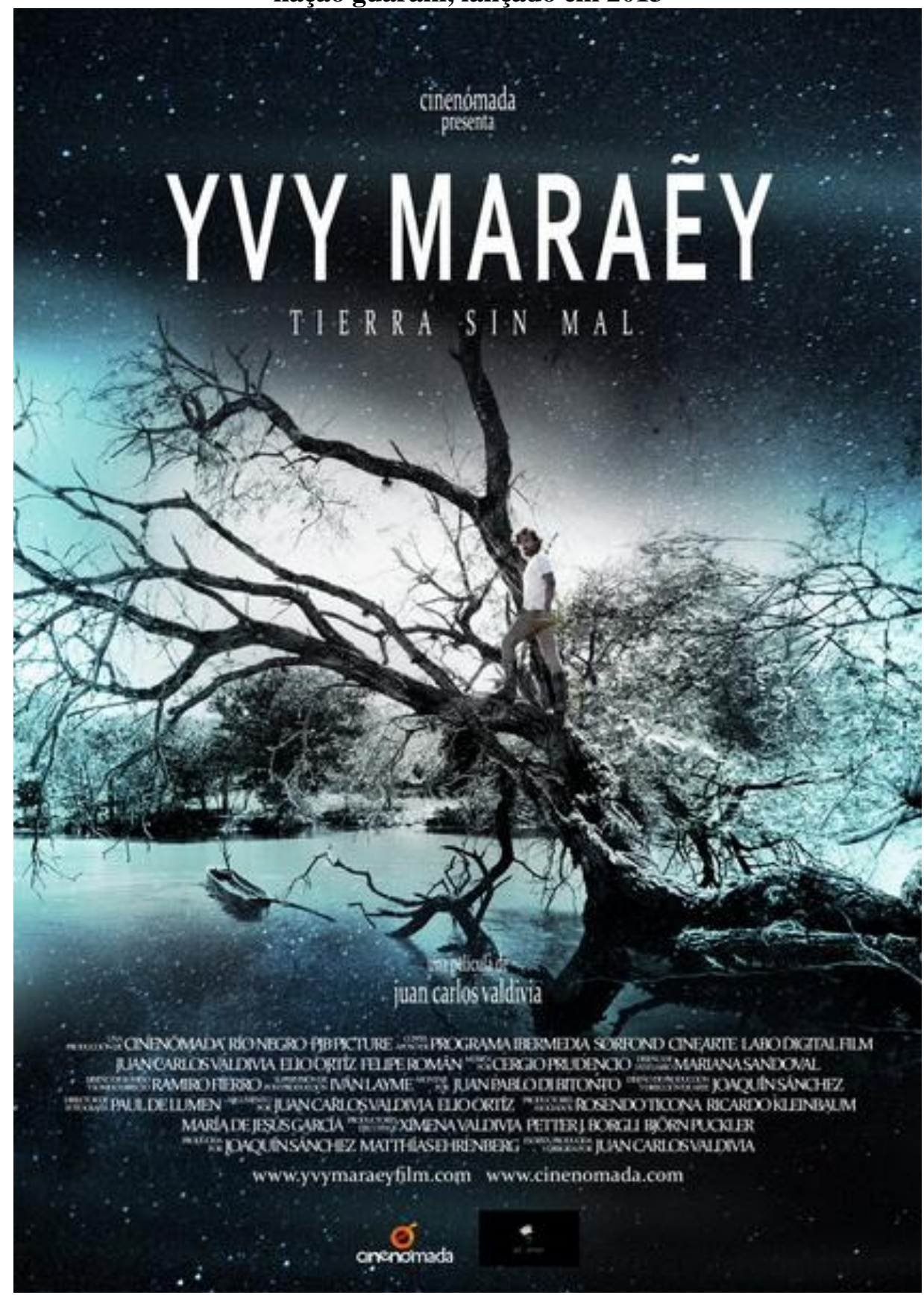

Fonte: Google imagens. 
Figura 44. Fotografia do filme Yvy maraey - Tierra sin mal, do diretor Juan Carlos Valdivia. O encontro intercultural entre o karai e o guarani

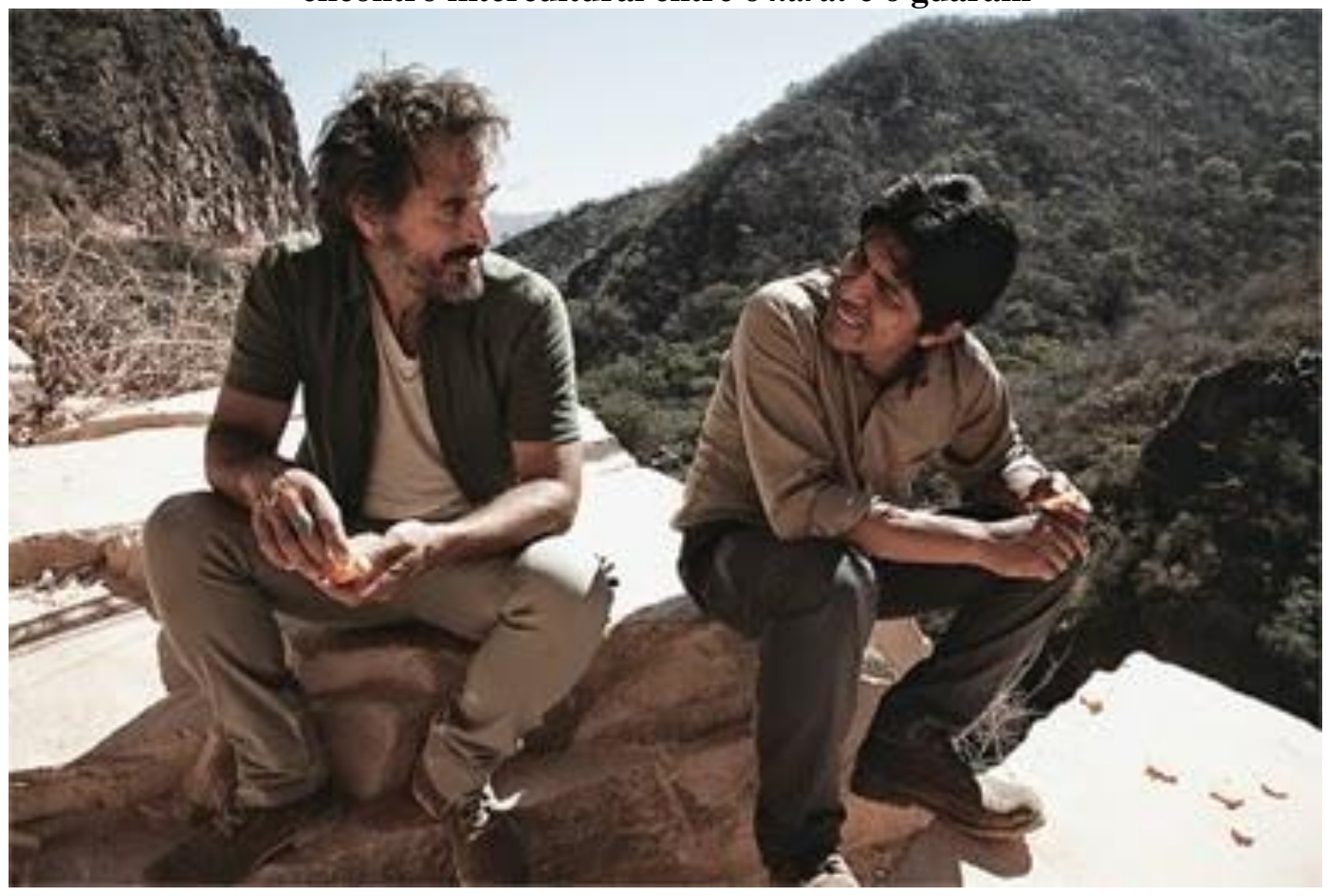

Fonte: <la-razon.com>.

Figura 45. Felipe Román, Juan Carlos Valdivia e Elio Ortiz no lançamento do filme Yvy maraey Tierra sin mal, em La Paz

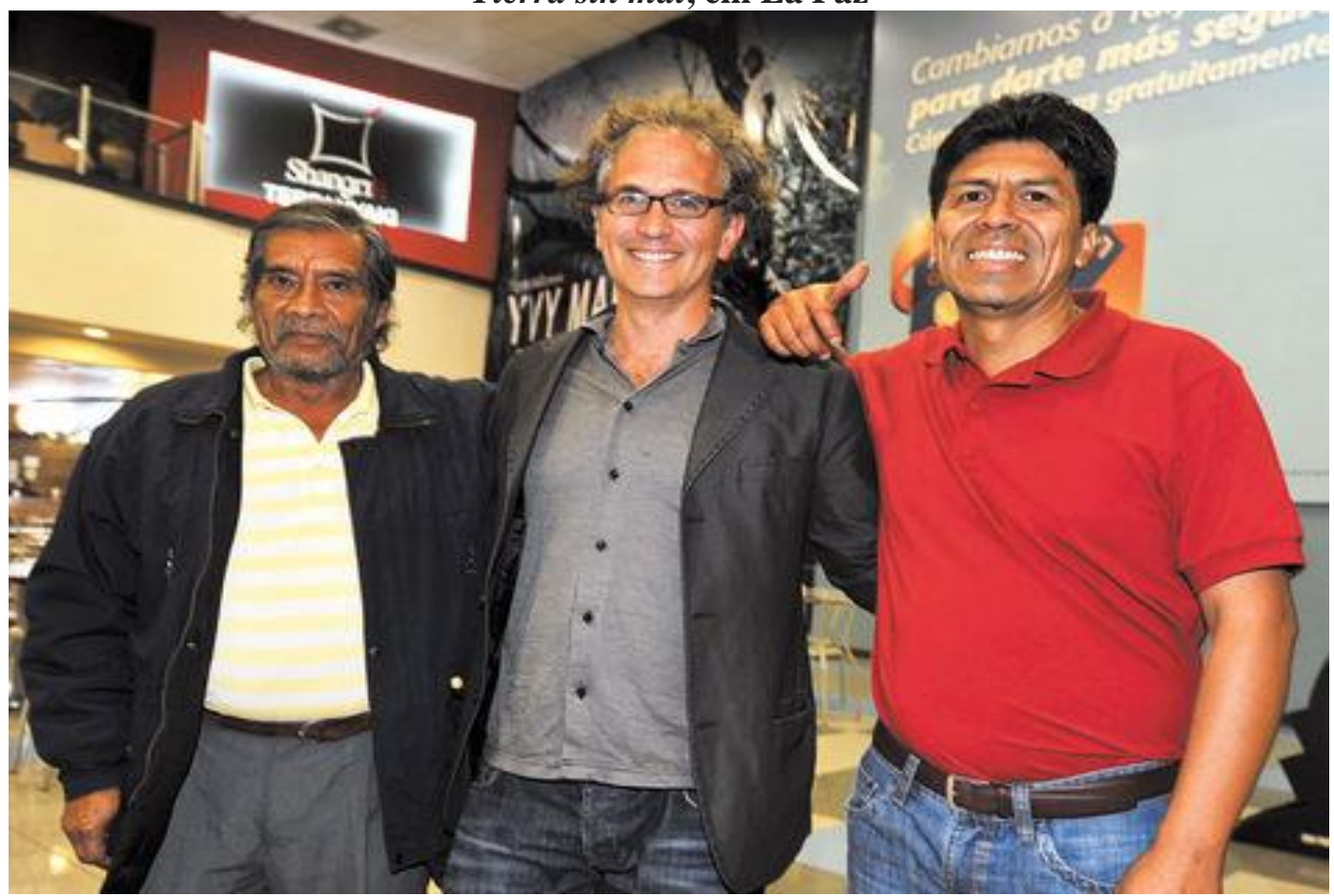

Fonte: <la-razon.com>. 